\title{
Antenatal and intrapartum interventions for preventing cerebral palsy: an overview of Cochrane systematic reviews (Review)
}

Shepherd E, Salam RA, Middleton P, Makrides M, McIntyre S, Badawi N, Crowther CA

Shepherd E, Salam RA, Middleton P, Makrides M, McIntyre S, Badawi N, Crowther CA.

Antenatal and intrapartum interventions for preventing cerebral palsy: an overview of Cochrane systematic reviews.

Cochrane Database of Systematic Reviews 2017, Issue 8. Art. No.: CD012077.

DOI: 10.1002/14651858.CD012077.pub2.

www.cochranelibrary.com 
HEADER 1

ABSTRACT

PLAIN LANGUAGE SUMMARY

BACKGROUND

OBJECTIVES

METHODS

RESULTS

Figure 1.

DISCUSSION

AUTHORS' CONCLUSIONS

ACKNOWLEDGEMENTS

REFERENCES

ADDITIONAL TABLES

APPENDICES

CONTRIBUTIONS OF AUTHORS

DECLARATIONS OF INTEREST

SOURCES OF SUPPORT

INDEX TERMS

\section{TABLE OF CONTENTS}

1

2

4

7 
[Overview of Reviews]

\section{Antenatal and intrapartum interventions for preventing cerebral palsy: an overview of Cochrane systematic reviews}

Emily Shepherd ${ }^{1}$, Rehana A Salam²,3, Philippa Middleton 1 ,3, Maria Makrides³, Sarah Mclntyre ${ }^{4}$, Nadia Badawi ${ }^{4,5}$, Caroline A Crowther1,6

1ARCH: Australian Research Centre for Health of Women and Babies, Robinson Research Institute, Discipline of Obstetrics and Gynaecology, The University of Adelaide, Adelaide, Australia. 2Division of Women and Child Health, Aga Khan University Hospital, Karachi, Pakistan. ${ }^{3}$ Healthy Mothers, Babies and Children, South Australian Health and Medical Research Institute, Adelaide, Australia. ${ }^{4}$ Research Institute, Cerebral Palsy Alliance, University of Sydney, Sydney, Australia. ${ }^{5}$ Grace Centre for Newborn Care, The Children's Hospital at Westmead, Sydney, Australia. ${ }^{6}$ Liggins Institute, The University of Auckland, Auckland, New Zealand

Contact address: Emily Shepherd, ARCH: Australian Research Centre for Health of Women and Babies, Robinson Research Institute, Discipline of Obstetrics and Gynaecology, The University of Adelaide, Adelaide, South Australia, 5006, Australia. emily.shepherd@adelaide.edu.au.

Editorial group: Cochrane Pregnancy and Childbirth Group. Publication status and date: New, published in Issue 8, 2017.

Citation: Shepherd E, Salam RA, Middleton P, Makrides M, McIntyre S, Badawi N, Crowther CA. Antenatal and intrapartum interventions for preventing cerebral palsy: an overview of Cochrane systematic reviews. Cochrane Database of Systematic Reviews 2017, Issue 8. Art. No.: CD012077. DOI: 10.1002/14651858.CD012077.pub2.

Copyright @ 2017 The Cochrane Collaboration. Published by John Wiley \& Sons, Ltd.

\section{A B S T R A C T}

\section{Background}

Cerebral palsy is an umbrella term encompassing disorders of movement and posture, attributed to non-progressive disturbances occurring in the developing fetal or infant brain. As there are diverse risk factors and causes, no one strategy will prevent all cerebral palsy. Therefore, there is a need to systematically consider all potentially relevant interventions for their contribution to prevention.

\section{Objectives}

To summarise the evidence from Cochrane reviews regarding the effects of antenatal and intrapartum interventions for preventing cerebral palsy.

\section{Methods}

We searched the Cochrane Database of Systematic Reviews on 7 August 2016, for reviews of antenatal or intrapartum interventions reporting on cerebral palsy. Two authors assessed reviews for inclusion, extracted data, assessed review quality, using AMSTAR and ROBIS, and quality of the evidence, using the GRADE approach. We organised reviews by topic, and summarised findings in text and tables. We categorised interventions as effective (high-quality evidence of effectiveness); possibly effective (moderate-quality evidence of effectiveness); ineffective (high-quality evidence of harm or of lack of effectiveness); probably ineffective (moderate-quality evidence of harm or of lack of effectiveness); and no conclusions possible (low- to very low-quality evidence).

\section{Main results}

We included 15 Cochrane reviews. A further 62 reviews pre-specified the outcome cerebral palsy in their methods, but none of the included randomised controlled trials (RCTs) reported this outcome. The included reviews were high quality and at low risk of bias. They included 279 RCTs; data for cerebral palsy were available from 27 (10\%) RCTs, involving 32,490 children. They considered interventions for: treating mild to moderate hypertension (two) and pre-eclampsia (two); diagnosing and preventing fetal compromise in labour (one); preventing preterm birth (four); preterm fetal maturation or neuroprotection (five); and managing preterm fetal compromise (one). Quality of evidence ranged from very low to high. 


\section{Effective interventions: high-quality evidence of effectiveness}

There was a reduction in cerebral palsy in children born to women at risk of preterm birth who received magnesium sulphate for neuroprotection of the fetus compared with placebo (risk ratio (RR) $0.68,95 \%$ confidence interval (CI) 0.54 to 0.87 ; five RCTs; 6145 children).

\section{Probably ineffective interventions: moderate-quality evidence of harm}

There was an increase in cerebral palsy in children born to mothers in preterm labour with intact membranes who received any prophylactic antibiotics versus no antibiotics (RR 1.82, 95\% Cl 0.99 to 3.34; one RCT; 3173 children). There was an increase in cerebral palsy in children, who as preterm babies with suspected fetal compromise, were born immediately compared with those for whom birth was deferred (RR $5.88,95 \% \mathrm{Cl} 1.33$ to 26.02 ; one RCT; 507 children).

\section{Probably ineffective interventions: moderate-quality evidence of lack of effectiveness}

There was no clear difference in the presence of cerebral palsy in children born to women at risk of preterm birth who received repeat doses of corticosteroids compared with a single course (RR 1.03, 95\% Cl 0.71 to 1.50; four RCTs; 3800 children).

\section{No conclusions possible: low- to very low-quality evidence}

Low-quality evidence found there was a possible reduction in cerebral palsy for children born to women at risk of preterm birth who received antenatal corticosteroids for accelerating fetal lung maturation compared with placebo (RR $0.60,95 \% \mathrm{Cl} 0.34$ to 1.03 ; five $\mathrm{RCTs}$; 904 children). There was no clear difference in the presence of cerebral palsy with interventionist care for severe pre-eclampsia versus expectant care (RR 6.01, 95\% Cl 0.75 to 48.14; one RCT; 262 children); magnesium sulphate for pre-eclampsia versus placebo (RR 0.34 , 95\% $\mathrm{Cl} 0.09$ to 1.26; one RCT; 2895 children); continuous cardiotocography for fetal assessment during labour versus intermittent auscultation (average RR 1.75, 95\% Cl 0.84 to 3.63; two RCTs; 13,252 children); prenatal progesterone for prevention of preterm birth versus placebo (RR $0.14,95 \% \mathrm{Cl} 0.01$ to 3.48; one RCT; 274 children); and betamimetics for inhibiting preterm labour versus placebo (RR $0.19,95 \% \mathrm{Cl} 0.02$ to 1.63 ; one RCT; 246 children).

Very low-quality found no clear difference for the presence of cerebral palsy with any antihypertensive drug (oral beta-blockers) for treatment of mild to moderate hypertension versus placebo (RR $0.33,95 \% \mathrm{Cl} 0.01$ to 8.01 ; one RCT; 110 children); magnesium sulphate for prevention of preterm birth versus other tocolytic agents (RR $0.13,95 \% \mathrm{Cl} 0.01$ to 2.51 ; one RCT; 106 children); and vitamin $\mathrm{K}$ and phenobarbital prior to preterm birth for prevention of neonatal periventricular haemorrhage versus placebo ( $\mathrm{RR} 0.77,95 \% \mathrm{Cl} 0.33$ to 1.76 ; one RCT; 299 children).

\section{Authors' conclusions}

This overview summarises evidence from Cochrane reviews on the effects of antenatal and intrapartum interventions on cerebral palsy, and can be used by researchers, funding bodies, policy makers, clinicians and consumers to aid decision-making and evidence translation. We recommend that readers consult the included Cochrane reviews to formally assess other benefits or harms of included interventions, including impacts on risk factors for cerebral palsy (such as the reduction in intraventricular haemorrhage for preterm babies following exposure to antenatal corticosteroids).

Magnesium sulphate for women at risk of preterm birth for fetal neuroprotection can prevent cerebral palsy. Prophylactic antibiotics for women in preterm labour with intact membranes, and immediate rather than deferred birth of preterm babies with suspected fetal compromise, may increase the risk of cerebral palsy. Repeat doses compared with a single course of antenatal corticosteroids for women at risk of preterm birth do not clearly impact the risk of cerebral palsy.

Cerebral palsy is rarely diagnosed at birth, has diverse risk factors and causes, and is diagnosed in approximately one in 500 children. To date, only a small proportion of Cochrane reviews assessing antenatal and intrapartum interventions have been able to report on this outcome. There is an urgent need for long-term follow-up of RCTs of interventions addressing risk factors for cerebral palsy, and consideration of the use of relatively new interim assessments (including the General Movements Assessment). Such RCTs must be rigorous in their design, and aim for consistency in cerebral palsy outcome measurement and reporting to facilitate pooling of data, to focus research efforts on prevention.

\section{PLAIN LANGUAGE SUMMARY}

\section{Interventions during pregnancy and childbirth for preventing cerebral palsy: an overview of Cochrane reviews}

\section{What is the issue?}

Cerebral palsy is a term that includes a group of conditions affecting people's ability to move, and is the most common physical disability in childhood. Cerebral palsy is usually due to events before, during, or after childbirth that lead to injury in babies' developing brains. There is no single cause of cerebral palsy. For many children, the cause of cerebral palsy is unclear, however, there are many known risk factors. The biggest risk factor is birth before 37 weeks of pregnancy (preterm birth). Other risk factors for mothers include some medical conditions (including thyroid problems), abnormalities of the placenta, pre-eclampsia (high blood pressure and protein in the urine), and 
some bacterial and viral infections. For babies, risk factors include congenital and genetic abnormalities, having a low birthweight or growth restricted as a fetus, being a twin or triplet, some infections, and prolonged loss of oxygen during birth.

\section{Why is this important?}

As there are different risk factors and causes for cerebral palsy, it is likely that various different interventions (treatments) may be needed to prevent cerebral palsy by reducing risk factors. This overview summarises the evidence about preventing cerebral palsy from Cochrane reviews of interventions during pregnancy and childbirth.

\section{What evidence did we find?}

We searched for evidence on 7 August 2016. We identified 15 Cochrane reviews that assessed interventions during pregnancy or childbirth that reported on cerebral palsy, with information from 27 randomised controlled trials involving 32,490 children. The reviews were all high quality, but the quality of the evidence about cerebral palsy ranged from very low to high.

The interventions assessed were for treating mild to moderate hypertension (two reviews), treating pre-eclampsia (two reviews), diagnosing or preventing fetal compromise (when the unborn baby may not be well) during labour (one review), preventing preterm birth (four reviews), maturing or protecting babies' lungs or brains before preterm birth (five reviews), and managing fetal compromise of preterm babies (one review).

We found high-quality evidence that one intervention was effective for cerebral palsy prevention: preterm children born to mothers who received magnesium sulphate before birth were less likely to develop cerebral palsy than children whose mothers received a placebo (five trials, 6145 children).

We found moderate-quality evidence that two interventions were probably ineffective, and could cause harm: (i) children born to mothers who had received antibiotics for preterm labour when their waters had not broken were more likely to develop cerebral palsy than children whose mothers did not receive antibiotics (one trial, 3173 children); and (ii) preterm children who were born immediately when there was suspected fetal compromise were more likely to develop cerebral palsy than those for whom birth was postponed (one trial, 507 children).

We found moderate-quality evidence that there was no clear difference in the chance of children to develop cerebral palsy whether their mothers received one or more courses of corticosteroids before preterm birth (four trials, 3800 children).

There was low-quality evidence as to whether the other interventions prevented, increased, or had no impact on cerebral palsy, although we did find that children born to mothers who received corticosteroids to help mature their lungs before preterm birth were potentially less likely to develop cerebral palsy than those born to mothers who received a placebo (five trials, 904 children).

\section{What does this mean?}

We identified one intervention that was effective in preventing cerebral palsy (magnesium sulphate before preterm birth), two that appeared to cause harm (preventive antibiotics for women in preterm labour when their waters have not broken, and immediate birth for preterm babies with suspected compromise), and one that did not appear to make a clear difference (more than one course of corticosteroids before preterm birth). For the other interventions assessed, there was not enough evidence to reach any conclusions. Further good quality randomised controlled trials, assessing interventions that might impact cerebral palsy risk factors, with long-term follow-up to measure cerebral palsy, are needed. We identified over 60 other Cochrane reviews that may provide more information in the future. 


\section{B A C K G R O U N D}

\section{Description of the condition}

\section{Cerebral palsy: definition and prevalence}

Cerebral palsy was originally defined by clinical description, at a time when there was little knowledge of causes, risk factors, or pathology. Discussion on the definition and classification was first recorded in English, French, and German medical literature in the nineteenth century; for over 150 years, there has been debate about what the term 'cerebral palsy' actually describes (Morris 2007). Definitions adopted by international cerebral palsy registries have commonly included those proposed by Bax in the 1960s (Bax 1964), Mutch and colleagues in the 1990s (Mutch 1992), and more recently, by Rosenbaum and colleagues (a revised version of Bax 1964): "Cerebral palsy describes a group of permanent disorders of the development of movement and posture, causing activity limitation, that are attributed to non-progressive disturbances that occurred in the developing fetal or infant brain. The motor disorders of cerebral palsy are often accompanied by disturbances of sensation, perception, cognition, communication, and behaviour, by epilepsy, and by secondary musculoskeletal problems" (Rosenbaum 2007).

Today, cerebral palsy is still a clinical description, but registries and surveillance programmes, such as those in Australia, the United Kingdom, and Europe, highlight five key elements that reflect the core features of cerebral palsy, provided in definitions, and proposed by the Surveillance of Cerebral Palsy in Europe (SCPE): (i) it is an 'umbrella term'; (ii) it is permanent but not unchanging; (iii) it involves a disorder of movement, posture, motor function, or a combination; (iv) it is due to a non-progressive interference, lesion, or abnormality; and (v) the interference, lesion, or abnormality arose in the developing or immature brain (Cans 2000; Mutch 1992; Rosenbaum 2007; Smithers-Sheedy 2014). As cerebral palsy is defined by clinical description, which may change over time, a longer time span for diagnosis is considered useful to confirm that the condition meets the criteria for cerebral palsy, and to accurately describe the motor impairment. Thus, final ascertainment for surveillance programmes across the world range from four to 12 years, with many considering data to be 'complete' at or near five years (Smithers-Sheedy 2014). While average age for diagnosis has been around 18 months, recent evidence has suggested that cerebral palsy may be reliably detected in high-risk infants as early as three to four months post-term age, using tests such as Prechtl's General Movements Assessment and medical resonance imaging (Bosanquet 2013; Morgan 2016).

Cerebral palsy can be described by its motor type and body parts distribution (topography). Primary and secondary motor types include spasticity, dyskinesia, ataxia, and hypotonia, which are determined by a combination of structured neurological and motor assessments, with observations sometimes corroborated by imaging findings (Cans 2000; Rosenbaum 2007; Sanger 2003). Spasticity is the predominant primary motor type. Frequently used terms to describe the topography are hemiplegia (unilateral involvement), diplegia (bilateral involvement), with the lower limbs more affected than the upper limbs, and quadriplegia (bilateral involvement), with the upper limbs more or equally involved. Monoplegia and triplegia are occasionally reported as separate entities, or grouped with hemiplegia and quadriplegia, respectively (Howard 2005; Sankar 2005).
Today, the Gross Motor Function Classification System (GMFCS) is used internationally as the principal way to classify gross motor function (Morris 2004; Palisano 1997; Wood 2000). It describes the gross movement ability of children in one of five ordinal levels, and provides descriptions for each level across five age bands: less than two years; two to four years; four to six years; six to 12 years; 12 to 18 years (Wood 2000). Unlike classifications based on motor type and topography, the GMFCS has been shown to be a valid, reliable, stable, and clinically relevant method for classification, and in conjunction with the Gross Motor Function Measure (GMFM), for prediction (after the age of two) of motor function in cerebral palsy (Palisano 1997; Wood 2000). The Manual Ability Classification System (MACS) provides a method analogous to the GMFCS for assessing the ability of children with cerebral palsy to handle objects (Eliasson 2006), and the Communication Function Classification System (CFCS) assists in evaluating the communication capacity in real-life situations for children with cerebral palsy (Hidecker 2011). One can draw a comprehensive picture of functional performance in daily life for individuals with cerebral palsy by using the GMFCS, MACS, and CFCS together, to inform both research and clinical practice (Compagnone 2014; Hidecker 2012).

Despite variation in definitions and classifications of cerebral palsy, there is wide agreement that it is the most common physical disability in childhood. In a recent meta-analysis of 19 studies, the global pooled birth prevalence was 2.11 per 1000 live births (95\% confidence interval 1.98 to 2.25 ); a cumulative meta-analysis demonstrated stability in the prevalence over the past 10 years (Oskoui 2013). Similar trends and relative stability of rates over time have been shown in geographical regions "with CP Registers" that have used consistent methods of ascertainment, with most published estimates of total population birth prevalence around two per 1000 live births (Blair 2006). In low- and middle-income countries, birth prevalence estimates have tended to be in a similar range, or higher, but it is difficult to meaningfully compare rates, since very few of these countries use registries or surveillance programmes (Blair 2006; Cans 2000; Colver 2014). However, there is now emerging evidence, including from Australia and Europe, that birth prevalence and severity of the condition are starting to decline for the first time (Reid 2016; Sellier 2015). Rate variations have also been observed, particularly when stratified by gestational age or birthweight. In the aforementioned meta-analysis, the prevalence was highest in children weighing 1000 to $1499 \mathrm{~g}$ at birth (59.18 per 1000 live births), and for children born before 28 weeks of gestation (111.80 per 1000 live births; Oskoui 2013).

\section{Cerebral palsy: causes and risk factors}

For approximately $6 \%$ of individuals with cerebral palsy, their brain injury is believed to have been acquired during a recognised event at least 28 days after birth and before the age of two to five; commonly, a cerebrovascular accident, spontaneous, associated with surgery or with complications of cardiac defects, or accidental and non-accidental head injuries (ACPR Group 2013). For the remaining $94 \%$ of individuals with cerebral palsy, their brain injury is believed to have occurred during the antenatal or the neonatal period of infant development, that is, during pregnancy, or within the first 28 days of life (ACPR Group 2013).

The pathogenesis of such brain injury is complex and multifactorial, with interrelated pathways contributing to cellular dysfunction and death, including accumulation of reactive oxygen species, the 
release of excitatory amino acids, energy depletion, and apoptosis (Inder 2000; Vexler 2001). There are multiple causes of brain injury, including hypoxia-ischaemia (characterised by reduced oxygen in the blood combined with reduced blood flow to the brain), haemorrhage, infection, maldevelopment, and metabolic derangement (Volpe 2000). Brain hypoxia (deficiency of oxygen) and ischaemia (insufficient blood supply) may lead to different neuropathology in infants born preterm and at term, with cerebral white matter injury predominating in preterm infants, and neuronal cell injury in term infants (Volpe 2000). Injury to the developing brain is known to be associated with long-term sequelae, including cerebral palsy, as well as hearing, sight, speech, and behavioural disorders, seizures, and intellectual disabilities (Vexler 2001).

Preterm birth is one of the principal risk factors for cerebral palsy and associated neurosensory disabilities (Himpens 2008; Oskoui 2013). The degree of prematurity is associated with vulnerability of cerebral white matter, and is predictive of an increasing risk of white matter injury (such as periventricular leukomalacia), and intraventricular haemorrhage (Larroque 2003), established risk factors for the development of cerebral palsy (Saliba 2001). Although preterm birth is acknowledged as a major risk factor for cerebral palsy, with over $40 \%$ of individuals with cerebral palsy being born preterm (compared with approximately $8 \%$ of the general population), most individuals with cerebral palsy (50\% to $60 \%$ ) are in fact, born at term (ACPR Group 2013).

Studies on possible risk factors for cerebral palsy for pretermand term-born individuals are abundant (with some risk factors reported more consistently than others). Evidence now suggests that $70 \%$ to $80 \%$ of cerebral palsy cases are associated with antenatal factors, with birth asphyxia playing a relatively minor role (Blair 1988; Ellenberg 2013; MacLennan 2015). Risk factors, in additional to preterm birth, often reported in the literature include: (a) factors prior to conception, such as: young or advanced maternal age, high parity, nulliparity, a short or long interpregnancy interval, a history of stillbirth, multiple miscarriages, neonatal death, or premature birth, family history of cerebral palsy and other genetic predispositions, low socioeconomic status, and pre-existing maternal conditions (e.g. intellectual disability, and epilepsy); (b) factors in early pregnancy, such as: male gender, multiple gestation, congenital malformations or birth defects, and infections (i.e. TORCH complex: toxoplasmosis (parasite), other infections, rubella, cytomegalovirus, herpes simplex virus); (c) factors during pregnancy, such as: maternal disease (e.g. thyroid disorders), pregnancy complications (e.g. high blood pressure, pre-eclampsia, placenta praevia, placental abruption, and other placental abnormalities), intrauterine infection or inflammation and chorioamnionitis, intrauterine growth restriction, and other precursors to preterm birth; and (d) factors around the time of birth and neonatal period, such as: an acute intrapartum hypoxic event, meconium aspiration, stroke, seizures, hypoglycaemia, jaundice, and infection, along with inborn errors of metabolism (such as glucose-6-phosphate dehydrogenase deficiency), particular syndromes, or chromosomal abnormalities (Jacobsson 2004; McIntyre 2011; McIntyre 2013; Nelson 2008b; Smithers-Sheedy 2014).

In low- and middle-income countries, the causes and risk factors for cerebral palsy are known to differ considerably (Blair 2006). With few survivors of very preterm birth in such countries, common risk factors are birth asphyxia and maternal Rhesus alloimmunisation, or inherited disorders, such as glucose-6phosphate dehydrogenase deficiency and subsequent bilirubin encephalopathy, and there are much higher proportions of children with postnatally acquired cerebral palsy, particularly associated with postinfectious brain damage following meningitis, septicaemia, and other conditions, such as malaria (Blair 2006; Lagunju 2009).

While a great number of potential risk factors for cerebral palsy have been identified, their commonality is that separately, or in combination, they may lead to injury to the developing brain. A growing body of evidence now suggests that genetic abnormalities may also contribute to the development of cerebral palsy (MorenoDe-Luca 2012; Oskoui 2015; O'Callaghan 2009). Previously, only 1\% to $2 \%$ of cerebral palsy cases were linked to a causative genetic mutation, but recent studies have shown that up to $14 \%$ have single gene mutations and $31 \%$ have copy number variations that may be at fault (MacLennan 2015). Possible genetic mutations and variants associated with cerebral palsy are likely to be heterogeneous, but they both trigger pathways (either directly, or in the case of genetic susceptibility, when certain risk factors are present), leading to nonprogressive neuropathology associated with motor dysfunction and cerebral palsy (MacLennan 2015). Though there is currently no known cure for cerebral palsy, increasing knowledge of risk factors and causal pathways had increased the hope for the development and implementation of primary preventive strategies: "we are on the move... the vision of prevention and cure no longer seems an unattainable goal" (Badawi 2013).

\section{Cerebral palsy: consequences}

Cerebral palsy is the leading cause of physical disability in children. Though traditionally regarded as a paediatric condition, it is now recognised that cerebral palsy is a condition with life-long impact a 'lifespan condition' - and thus, the outcomes of individuals with cerebral palsy across the life course are considered when planning and directing interventions in childhood (Colver 2014).

Most individuals with cerebral palsy will survive to adulthood, with some studies suggesting life expectancy can be broadly similar to that of the general population if a child reaches adolescence (Colver 2012). For known cases of antenatally- or neonatally-acquired cerebral palsy, the 20-year survival rate has been estimated to be approximately $90 \%$, however, strong associations between increasing motor impairment, severe intellectual impairment, number of severe impairments, and early mortality have been shown (Blair 2001; Hemming 2005; Reid 2012). While a mixed picture in overall survival trends has been presented to date, some improvements in survival have been observed over time for two groups of individuals with cerebral palsy with the most severe disabilities - children who are largely immobile and fed by others, and adults who are dependent on gastrostomy feeding (Strauss 2008).

Today's frequently used definitions importantly acknowledge cooccurring impairments, diseases, and functional limitations, which are common among individuals with cerebral palsy, including hearing, sight, and speech disorders, intellectual disability and epilepsy (Rosenbaum 2007). A recent systematic review estimated, for example, that among children with cerebral palsy, " 1 in 2 had an intellectual disability... 1 in 4 could not talk; 1 in 4 had epilepsy; 1 in 4 had a behaviour disorder... 1 in 10 were blind... and 1 in 25 were deaf" (Novak 2012). 
Economic studies have estimated lifetime costs of cerebral palsy, including healthcare costs (such as primary health care, hospital care, and pharmaceuticals), social care costs (such as specialised education and housing), and productivity costs (the cost for society when an individual never enters the labour market, or leaves it) as EUR860,000 for men and EUR800,000 for women in Denmark (in 2000; Kruse 2009), and USD921,000 for individuals in the United States (in 2003; CDC 2004). In Australia, the financial cost of cerebral palsy was estimated AUD1.47 billion (in 2007); the value of lost wellbeing (disability and premature death) was a further AUD2.4 billion (Access Economics 2008).

The impacts of cerebral palsy are considerable, not only for individuals, but for families, carers, communities, and societies (Davis 2010). Accordingly, individuals with cerebral palsy and their families, clinicians and researchers recognise that identification of primary preventive measures continues to be a key priority (Mclntyre 2010).

\section{Description of the interventions}

\section{Antenatal or intrapartum approaches to prevention of cerebral palsy}

Research efforts aimed at moving towards a future without cerebral palsy have increasingly focused on understanding the causes of cerebral palsy. As it is now widely recognised that causes differ, for example, by gestational age (i.e. for preterm- and term-born children), and clinical subtype of cerebral palsy (Nelson 2008), it is reasonable to consider that successful primary preventive interventions may also vary according to different aetiologies and causal factors. For example, spastic diplegia is the most common subtype of cerebral palsy in preterm infants, most often caused by white matter injury initiated by cerebral ischaemia, maternal intrauterine infection, or fetal systemic inflammation; quadriplegic cerebral palsy, especially with dyskinesia, is a subtype of cerebral palsy sometimes related to acute asphyxia during the birth process (Nelson 2008).

Primary preventive interventions may include public health strategies for the general population (e.g. periconceptional folate supplementation to reduce birth defects), strategies directed at preventing distal components on a causal pathway to cerebral palsy (e.g. melatonin for small-for-gestational age in pregnancy), and strategies closer to the proximal cause of brain damage (e.g. magnesium sulphate for neuroprotection immediately prior to very preterm birth; IMPACT for CP 2011).

Therefore, we considered a broad range of antenatal and intrapartum interventions ${ }^{*}$ in this overview, with varying primary aims and indications, which may mediate the risk of cerebral palsy. The examples presented below are not an exhaustive list, but include:

- nutrition interventions in pregnancy, e.g. periconceptional folate supplementation; marine oil, and other prostaglandin precursors; vitamins $\mathrm{C}$ and $\mathrm{E}$;

- behaviour or advice interventions in pregnancy, e.g. reducing alcohol and drug consumption; supporting smoking cessation; promoting hand-washing;

- interventions for predicting or preventing preterm birth (including subsequent management strategies), e.g. fetal fibronectin testing; cervical assessment by ultrasound; risk- scoring systems; transfer to a hospital with neonatal intensive care unit facilities; cervical cerclage; cervical pessary; prenatal administration of progesterone; acute tocolytic and maintenance therapy (i.e. magnesium sulphate; calcium channel blockers (nifedipine); oxytocin receptor antagonists (atosiban); betamimetics (terbutaline); cyclo-oxygenase (COX) inhibitors (indomethacin));

- interventions prior to preterm or term birth for fetal neuroprotection, e.g. antenatal corticosteroids; repeat doses of corticosteroids; thyrotropin-releasing hormone added to corticosteroids; magnesium sulphate; creatine; melatonin; phenobarbital; vitamin K;

- screening and management of fetal growth and well-being in pregnancy, e.g. fetal movement counting for assessment of well-being; symphysial fundal height (SFH) measurement for detecting abnormal fetal growth; ultrasound for fetal assessment in early pregnancy; routine ultrasound in late pregnancy; antenatal cardiotocography for fetal assessment; fetal and umbilical Doppler ultrasound; utero-placental Doppler ultrasound; interventions for impaired fetal growth;

- diagnosing and preventing fetal compromise in labour, e.g. intermittent auscultation (IA) of fetal heart rate; continuous cardiotocography (CTG) for electric fetal heart rate monitoring (EFM); fetal electrocardiogram (ECG); fetal pulse oximetry; patient safety programmes;

- interventions for infection during pregnancy, e.g. TORCH, urinary tract infections, other vaginal infections (i.e. bacterial vaginosis);

- interventions for preterm and term pre-labour rupture of membranes, e.g. planned early birth (versus expectant management); antibiotics; tocolytics;

- other specific interventions for medical problems in pregnancy and labour, e.g. screening and subsequent management for thyroid dysfunction; anti-D administration for preventing Rhesus alloimmunisation in Rh-negative women; interventions for the treatment of mild to moderate, or severe hypertension, and for the prevention (i.e. antioxidants; antiplatelet agents) and treatment of pre-eclampsia or eclampsia (i.e. magnesium sulphate; lytic cocktail; diazepam; phenytoin); interventions for placenta praevia or placental abruption; interventions for uterine rupture or cord prolapse.

*We will not consider interventions in the neonatal period (such as cooling for newborns with hypoxic ischaemic encephalopathy (Jacobs 2013)), as these interventions will be assessed in a separate overview which will be focused specifically on neonatal interventions for prevention of cerebral palsy (Shepherd 2016).

\section{How the intervention might work}

Advances in research into several factors that modify the risk of cerebral palsy in infants suggest many opportunities for prevention, with some of the main strategies focusing on the prevention of preterm birth, or protection of the developing fetal brain through antenatal administration of neuroprotective agents.

For example, because preterm birth and neurodevelopmental outcomes are so strongly associated (ACPR Group 2013; Oskoui 2013), it is possible that interventions to prolong gestation or reduce the risk of preterm birth will also reduce the risk of cerebral palsy (Chang 2015; O'Shea 2008). Specific approaches, supported by high level evidence, for prolonging pregnancy 
and preventing preterm birth include: interventions for primary prevention of preterm birth (e.g. smoking cessation programmes for the general population); interventions for secondary prevention of indicated preterm birth (e.g. antiplatelet drugs (low-dose aspirin) for the prevention of pre-eclampsia); interventions for secondary prevention of spontaneous preterm birth (e.g. progesterone and cervical cerclage for women at increased risk of preterm birth due to a prior preterm birth, or where a short cervix has been identified on ultrasound); and tertiary interventions, for women with immediate risk of preterm birth (e.g. antibiotics for women with preterm rupture of membranes; and calcium channel blockers and an oxytocin antagonist (atosiban) for women with preterm labour; lams 2008; O’Shea 2008).

For women with immediate risk of preterm birth, it is possible that antenatal interventions aimed at protecting the developing fetal brain from injury will also reduce the risk of cerebral palsy. For example, antenatal corticosteroids to accelerate fetal lung maturation in women at risk of preterm birth have also been shown to be neuroprotective, reducing the risk of intraventricular haemorrhage and periventricular leukomalacia (Chang 2015; lams 2008; O'Shea 2008). Magnesium sulphate is another drug administered antenatally, with the potential to mediate the risk of cerebral palsy by protecting the developing fetal brain from injury, such as intraventricular haemorrhage (Chang 2015; Nelson 2008; O'Shea 2008). Beyond antenatal corticosteroids and magnesium sulphate, a range of other antenatally administered agents, such as melatonin, creatine, and allopurinol, may enhance the ability of the preterm or term developing fetal brain to withstand brain damage, and in doing so, reduce the risk of cerebral palsy (Chang 2015; Robertson 2012).

There are numerous other antenatal and intrapartum interventions with the potential to contribute to the prevention of cerebral palsy in preterm and term infants by modifying known risk factors for cerebral palsy, for example: identification and subsequent management of maternal thyroid dysfunction (both hypo- and hyper-thyroidism) in pregnancy, identification and treatment of hypertension and pre-eclampsia in pregnancy, and identification and management of perinatal infections (including chorioamnionitis) in pregnancy.

\section{Why it is important to do this overview}

A multitude of individual studies and Cochrane reviews assessing a broad range of antenatal or intrapartum interventions (with varying primary aims and indications) recognise the potential for the interventions of interest to mediate the risk of cerebral palsy. With the acknowledgement that a multiplicity of risk factors impact on the risk of cerebral palsy, and that causes of cerebral palsy differ, there is a need to systematically consider all potentially relevant interventions for their ability to contribute to prevention. To our knowledge, there is no published overview that has assembled and summarised the evidence from Cochrane reviews on interventions for the prevention of cerebral palsy in one coherent document, to be used by researchers, funding bodies, policy makers, clinicians, and consumers to aid decision making and evidence translation.

\section{OB JECTIVES}

The objective of this overview was to summarise the evidence from Cochrane reviews regarding the effects of antenatal and intrapartum interventions for preventing cerebral palsy, and to assess the effects of these interventions on associated outcomes, including severity and type of cerebral palsy.

\section{METHODS}

\section{Criteria for considering reviews for inclusion}

In this overview, we included Cochrane reviews of antenatal or intrapartum interventions, where cerebral palsy was reported as a primary or secondary outcome, or as part of a composite outcome, with data reported for cerebral palsy from at least one of the trials included in the review.

We identified relevant Cochrane protocols for future inclusion, and classified them as 'Ongoing reviews' (Appendix 1).

We listed reviews that pre-specified cerebral palsy as a primary or secondary outcome, but had no data reported from included trials as 'Reviews awaiting further classification', which will be reconsidered in future updates of the overview (Appendix 2).

We made note of the publication and search dates of the reviews, however, we did not attempt to update the individual reviews. We contacted the Cochrane Pregnancy and Childbirth Editorial Base to identify any relevant new reviews or review updates that were in progress, in order to include the most up-to-date versions of the reviews, if and where possible.

\section{Participants}

We considered reviews assessing interventions in pregnant women.

\section{Interventions}

We considered all types of interventions used in the antenatal or intrapartum period, compared with placebo, no treatment, or an alternative intervention.

We planned to include pharmacological, medical, nutritional, behavioural, and educational interventions (see Description of the interventions for further descriptions of possible interventions).

\section{Outcomes of interest}

Primary

- Cerebral palsy (however defined by review authors and trialists).

\section{Secondary}

- Cerebral palsy or death (e.g. in early childhood, and at the latest time point measured).

- Severity of cerebral palsy (e.g. according to: Gross Motor Function Classification System (GMFCS); Manual Ability Classification System (MACS); Communication Function Classification System (CFCS)).

- Other composite outcomes that included cerebral palsy as a component.

- Type of cerebral palsy (e.g. according to topography (diplegia; hemiplegia; quadriplegia; monoplegia; triplegia), or motor type (spastic; dyskinetic; ataxic)).

- Motor dysfunction (e.g. in infancy and early childhood, and at the latest time point measured; however defined by review authors and trialists) 


\section{Search methods for identification of reviews}

We searched the Cochrane Database of Systematic Reviews, using the term 'cerebral palsy', on 7 August 2016. We searched 'all text', and did not limit our search to 'title, abstract, or keywords'. We did not apply any language or date restrictions. No other databases were searched. We managed citations retrieved through the search with Covidence (Covidence 2015).

\section{Data collection and analysis}

We followed the methodology for data collection and synthesis from Chapter 22 of the Cochrane Handbook of Systematic Reviews of Interventions (Higgins 2011). Where appropriate, we prepared the overview using Covidence and Review Manager 5 software (Covidence 2015; RevMan 2014).

\section{Selection of reviews}

Two overview authors independently assessed all potential reviews we identified. We resolved any disagreement through discussion, or if required, we consulted a third author.

\section{Data extraction and management}

Two overview authors independently extracted data from the reviews using a pre-defined data extraction form. We resolved discrepancies through discussion. Where any information from the reviews was unclear or missing, we accessed the published papers of the individual studies.

We extracted information on the following.

- Review characteristics:

* review title and authors;

* date that the review was last assessed as up-to-date;

* number of included trials, number of participants (women and infants) in the trials and their characteristics (e.g. countries where the trials were conducted and inclusion criteria for the trials);

* quality of the included trials (as reported by the review authors; see Assessment of methodological quality of included reviews);

* interventions and comparisons relevant to this overview;

* all pre-specified outcomes relevant to this overview;

* any other characteristics required to assess and report on review quality (see Assessment of methodological quality of included reviews).

- Statistical summaries:

* the summary intervention effects (including the pooled effects (e.g. risk ratios (RR), odds ratios (OR) or mean differences (MD) as reported in the individual reviews), 95\% confidence intervals (Cls), and numbers of studies and participants contributing data to each pooled effect) for outcomes relevant to this overview (N.B. if the summary statistic (RR or OR) has been calculated using a randomeffects analysis, the results are presented as the 'average' treatment effect);

* information required to assess and report on the quality of the evidence for the intervention effects extracted above (see Assessment of methodological quality of included reviews);

* results of any subgroup or sensitivity analyses conducted by the review authors, for our primary outcome.
If there were no meta-analyses in a review, and therefore, no statistical summaries, we extracted the narrative text relating to the results for our overview outcomes.

When cerebral palsy was reported as part of a composite outcome, we extracted any available data on cerebral palsy. Where it was not possible to extract only the cerebral palsy data, we reported the composite outcome data; however, we reported it separately, as a secondary outcome.

\section{Assessment of methodological quality of included reviews \\ Quality of included reviews}

We assessed the methodological quality of each systematic review using the AMSTAR (A Measurement Tool to Assess Reviews) instrument (Shea 2009). AMSTAR evaluates the methods used in a review against 11 distinct criteria and assesses the degree to which review methods are unbiased. Each item on AMSTAR is rated as yes (clearly done), no (clearly not done), cannot answer, or not applicable. These criteria are as follows.

1. Was an a priori design provided?

2. Was there duplicate study selection and data extraction?

3. Was a comprehensive literature search performed?

4. Was the status of publication used as an inclusion criterion?

5. Was a list of studies (included and excluded) provided?

6. Were the characteristics of the included studies provided?

7. Was the scientific quality of the included studies assessed and documented?

8. Was the scientific quality of the included studies used appropriately in formulating conclusions?

9. Were the methods used to combine the findings of studies appropriate?

10.Was the likelihood of publication bias assessed?

11.Was the conflict of interest stated?

For all items except item 4, a rating of 'yes' was considered adequate. For item 4, a rating of 'no' was considered adequate. A review that adequately met all of the 11 criteria was considered to be a review of the highest quality. For this overview, we considered reviews that achieved scores of between 8 to 11 as high quality; scores of 4 to 7 as medium quality; and scores of 0 to 3 as low quality.

To further assess the risk of bias of the systematic reviews, we used the new ROBIS (Risk Of Bias In Systematic reviews) tool (Whiting 2014). The tool considers risk of bias across four key domains.

1. Study eligibility criteria.

2. Identification and selection of studies.

3. Data collection and study appraisal.

4. Synthesis and findings.

A series of questions within each of the domains elicits information about possible limitations of the systematic review, leading to a judgement about the concerns within that domain (low, high, or unclear). Assessors then consider the risk of bias of the review as a whole, with signalling questions and information to support the overall judgement of risk of low, high or unclear bias (Whiting 2014). 
Two overview authors independently assessed the quality of the included reviews; another overview author verified this assessment. We resolved differences through discussion.

\section{Quality of included studies within reviews}

We did not reassess the quality of included studies within reviews but reported study quality according to the review authors' assessment. When individual studies were included in two or more Cochrane reviews, we reported this, along with any variation in the review authors' assessments of study quality. We collected this information during the data extraction process.

\section{Quality of evidence in included reviews}

We assessed the quality of the evidence for our primary outcome (cerebral palsy) and secondary review outcomes using the GRADE approach, as outlined in the GRADE Handbook (Schünemann 2013). We reported the quality of evidence as assessed by the review authors (who were in the best position to assess quality given their familiarity with the study-level data), using 'Summary of findings' tables from the reviews if provided. Where necessary, we constructed tables using GRADEpro GDT software (GRADEpro GDT 2015). The GRADE system assesses the following features for the evidence found for important outcomes.

- Study limitations (risk of bias): internal validity of the evidence.

- Inconsistency: heterogeneity or variability in the estimates of effect across studies.

- Indirectness: degree of differences between population, intervention, comparator, for the intervention and outcome of interest.

- Imprecision (random error): extent to which confidence in the effect estimate is adequate to support a particular decision.

- Publication bias: degree of selective publication of studies.

The GRADE system rates the quality of the evidence as:

- High (further research is very unlikely to change confidence in the estimate of effect).

- Moderate (further research is likely to have an important impact on confidence in the estimate of effect and may change the estimate).

- Low (further research is very likely to have an important impact on confidence in the estimate of effect and is likely to change the estimate).

- Very low (any estimate of effect is very uncertain).

\section{Data synthesis}

We used a narrative description of the characteristics of the included Cochrane reviews.

We summarised the main results of the included reviews by categorising their findings in the following framework, organised by antenatal or intrapartum intervention, and by intervention topic. This approach was used in previous Cochrane and non-Cochrane overviews (i.e. Farquhar 2015; Lassi 2015). A similar approach was also used in Jones 2012, in which interventions were categorised as 'what works', 'what may work', and 'insufficient evidence to make a judgement'.

- Effective interventions: indicated that the review found highquality evidence of effectiveness for an intervention.

- Possibly effective interventions: indicated that the review found moderate-quality evidence of effectiveness for an intervention, but more evidence is needed.

- Ineffective interventions: indicated that the review found highquality evidence of lack of effectiveness (or harm) for an intervention.

- Probably ineffective interventions: indicated that the review found moderate-quality evidence suggesting lack of effectiveness (or harm) for an intervention, but more evidence is needed.

- No conclusions possible: indicated that the review found low or very low-quality evidence, or insufficient evidence to comment on the effectiveness or safety of an intervention.

The choice of category was based on the quality of the evidence for cerebral palsy. We used separate assessments for different comparisons if required (e.g. where one intervention was compared with both placebo (or no treatment) and an alternative intervention).

\section{RE S U L T S}

Our search of the Cochrane Database of Systematic Reviews identified 500 protocols and reviews. Following our review of titles and abstracts, we excluded 381 protocols and reviews, and assessed the full-text of 119 protocols and reviews.

We excluded 33 reviews that did not pre-specify cerebral palsy as a primary or secondary review outcome (see Table 1: Characteristics of excluded studies).

We listed 71 protocols and reviews in the appendices.

- Appendix 1, Ongoing reviews, lists nine Cochrane protocols that have pre-specified cerebral palsy as a primary or secondary outcome, and will be considered for inclusion in future updates of the overview when they are published as full reviews.

- Appendix 2, Reviews awaiting further classification, summarises the 62 Cochrane reviews that pre-specified cerebral palsy as a primary or secondary outcome, but the included trials had no data reported on this outcome; these reviews will again be considered for inclusion in future updates of the overview.

We included 15 reviews in this overview. See Figure 1. Review flow diagram, for details. 
Figure 1. Review flow diagram.

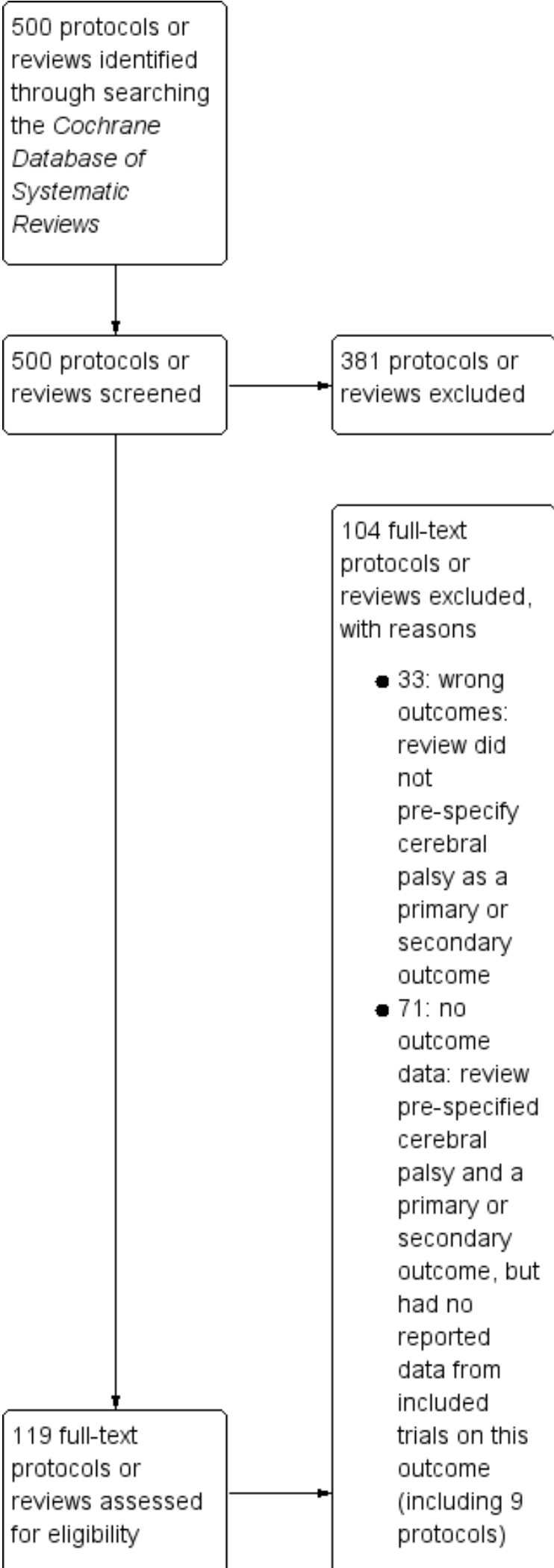


Figure 1. (Continued)



\section{Description of included reviews}

Of the 15 included reviews:

- two focused on the treatment of mild to moderate hypertension:

* antihypertensive drug therapy for mild to moderate hypertension during pregnancy (Abalos 2014);

* oral beta-blockers for mild to moderate hypertension during pregnancy (Magee 2003).

- two assessed interventions for the treatment of pre-eclampsia:

* interventionist versus expectant care for severe preeclampsia between 24 and 34 weeks' gestation (Churchill 2013);

* magnesium sulphate and other anticonvulsants for women with pre-eclampsia (Duley 2010).

- one focused on interventions for the diagnosis and prevention of fetal compromise in labour:

* continuous cardiotocography (CTG) as a form of electronic fetal monitoring (EFM) for fetal assessment during labour (Alfirevic 2013).

- four assessed interventions for the prevention of preterm birth:

* prenatal administration of progesterone for preventing preterm birth in women considered to be at risk of preterm birth (Dodd 2013);

* prophylactic antibiotics for inhibiting preterm labour with intact membranes (Flenady 2013);

* magnesium sulphate for preventing preterm birth in threatened preterm labour (Crowther 2014);

* betamimetics for inhibiting preterm labour (Neilson 2014).

- five focused on interventions prior to preterm birth for fetal maturation or neuroprotection:

* vitamin $\mathrm{K}$ prior to preterm birth for preventing neonatal periventricular haemorrhage (Crowther 2010);

* phenobarbital prior to preterm birth for preventing neonatal periventricular haemorrhage (Crowther 2010a);

* magnesium sulphate for women at risk of preterm birth for neuroprotection of the fetus (Doyle 2009);

* repeat doses of prenatal corticosteroids for women at risk of preterm birth for improving neonatal health outcomes (Crowther 2015);

* antenatal corticosteroids for accelerating fetal lung maturation for women at risk of preterm birth (Roberts 2006).

- one focused on interventions for the management of preterm fetal compromise:

* immediate versus deferred delivery of the preterm baby with suspected fetal compromise for improving outcomes (Stock 2016).
The number of randomised controlled trials (RCT) in the 15 reviews ranged from one (Stock 2016) to 49 (Abalos 2014). The number of women in each RCT ranged from 425 (Churchill 2013) to 37,715 (Alfirevic 2013). In total, there were 279 randomised trials, involving over 101,098 women and their babies.

One third (five) of the 15 reviews had conducted searches between August 2013 and August 2016, and were considered up-to-date (Crowther 2014; Crowther 2015; Flenady 2013; Neilson 2014; Stock 2016). The other 10 reviews had latest search dates ranging from August 2008 to April 2013.

See Table 2, Characteristics of included reviews and Table 3, Risk of bias assessments from included reviews, for further details of the characteristics of the 15 included reviews.

\section{Methodological quality of included reviews}

According to AMSTAR criteria:

1. all reviews pre-specified their design;

2. all reviews reported duplicate study selection and data extraction;

3. all reviews performed a comprehensive literature search;

4. all reviews considered grey literature;

5. all reviews provided lists of included and excluded studies;

6. all reviews provided the characteristics of the included studies;

7. all reviews assessed and documented the scientific quality of the included studies;

8. all reviews used scientific quality of the included studies appropriately in formulating conclusions;

9. 11 reviews combined the findings of studies using appropriate methods; in three reviews, fixed-effect meta-analyses were used despite the presence of substantial statistical heterogeneity; one review had only one included trial;

10.11 reviews assessed the likelihood of publication bias (or prespecified which methods they would use if 10 or more trials were included in a meta-analysis);

11.three reviews clearly reported conflict of interests or potential sources of support for both the review and included studies.

See Table 4: AMSTAR assessments for included reviews, for further details.

When assessed against the ROBIS domains, all reviews were considered at low risk of bias across the study eligibility criteria, identification and selection of studies, and data collection and study appraisal domains. Three of the reviews received an unclear risk of bias rating for the synthesis and findings domain (based on use of fixed-effect meta-analyses in the presence of substantial 
statistical heterogeneity). See Table 5: ROBIS assessments for included reviews, for further details.

Overall, all 15 included reviews were judged to be of high quality according to AMSTAR criteria, with scores ranging from 8 to 11 , and at a low risk of bias, according to ROBIS domains.

\section{Effect of interventions}

We have summarised the main results of the included reviews below. They are organised by intervention topic and categorised in the framework discussed under Data synthesis, based on the quality of the evidence for the presence of cerebral palsy, the primary outcome.

For further details and 'Summary of findings' tables for the outcomes of interest, see Table 6, All comparisons measuring cerebral palsy; Table 7, Subgroup or sensitivity analyses of select comparisons for cerebral palsy; Table 8, All comparisons measuring cerebral palsy or death; Table 9, All comparisons measuring severity of cerebral palsy; Table 10, All comparisons measuring other composite outcomes that include cerebral palsy as a component; and Table 11, All comparisons measuring motor dysfunction.

\section{Interventions for the treatment of mild to moderate hypertension}

\section{No conclusions possible: very low-quality evidence}

Very low-quality evidence in both the Abalos 2014 and Magee 2003 reviews showed no clear difference for the presence of cerebral palsy at one year when any antihypertensive drug was compared with a placebo (Abalos 2014), or when an oral beta-blocker was compared with placebo (Magee 2003), in the treatment of mild to moderate hypertension during pregnancy (risk ratio (RR) 0.33 , 95\% confidence interval ( $\mathrm{Cl}) 0.01$ to 8.01; one trial; 110 children; Table 6). The two reviews included the same trial, and made similar judgements regarding trial quality.

\section{Interventions for the treatment of pre-eclampsia}

\section{No conclusions possible: low-quality evidence}

Low-quality evidence in the Churchill 2013 review showed no clear difference for the presence of cerebral palsy at two years when interventionist care was compared with expectant (delayed delivery) care for severe pre-eclampsia between 24 and 34 weeks' gestation (RR $6.01,95 \% \mathrm{Cl} 0.75$ to 48.14 ; one trial; 262 children; Table 6).

Low-quality evidence in the Duley 2010 review showed no clear difference for the presence of severe cerebral palsy at 18 months when magnesium sulphate was compared with placebo for women with pre-eclampsia (RR $0.34,95 \% \mathrm{Cl} 0.09$ to 1.26; one trial; 2895 children; Table 6; Table 9).

Low-quality evidence in the Duley 2010 review also showed no clear difference in neurosensory disability (composite outcome that included cerebral palsy) at 18 months (RR $0.77,95 \% \mathrm{Cl} 0.38$ to 1.58; one trial; 3283 children; Table 10), or in death or neurosensory disability at 18 months (RR $1.06,95 \% \mathrm{Cl} 0.90$ to 1.25 ; one trial; 3283 children; Table 10) when magnesium sulphate was compared with placebo for women with pre-eclampsia.

\section{Interventions for the diagnosis and prevention of fetal compromise in labour}

\section{No conclusions possible: low-quality evidence}

Low-quality evidence in the Alfirevic 2013 review showed no clear difference for the presence of cerebral palsy in early childhood (between 18 months and four years) when continuous cardiotocography was compared with intermittent auscultation for fetal assessment during labour (average RR $1.75,95 \% \mathrm{Cl} 0.84$ to 3.63; two trials; 13,252 children; Table 6).

Alfirevic 2013 conducted subgroup analyses for the presence of cerebral palsy, based on pregnancy risk status, onset of labour, gestational age, number of babies, access to fetal blood sampling, parity, and and only high quality trials, however, did not identify any clear subgroup differences (Table 7).

\section{Interventions for the prevention of preterm birth}

\section{Probably ineffective interventions: moderate-quality evidence of harm}

Moderate-quality evidence in the Flenady 2013 review showed an increase in cerebral palsy in mid-childhood (at seven years) for children born to mothers who received any prophylactic antibiotics versus no antibiotics for inhibiting preterm labour with intact membranes (RR 1.82, 95\% Cl 0.99 to 3.34; one trial; 3173 children; Table 6).

Subgroup analysis for this outcome, based on type of antibiotic did not reveal clear subgroup differences (Table 7). Additional analyses were conducted for this outcome, comparing (i) any macrolide antibiotics (including macrolide antibiotics used as a single agent or in combination with other types of antibiotics) versus no macrolide antibiotics (including use of any non-macrolide antibiotics or no antibiotics), and (ii) any beta-lactam antibiotics (including beta-lactam antibiotics used as a single agent or in combination with other types of antibiotics) versus no beta-lactam antibiotics (including use of any non-beta-lactam antibiotics or no antibiotics). An increase in cerebral palsy in mid-childhood (at seven years) was observed for children born to mothers who received any macrolide versus no macrolide antibiotics, and any beta-lactam versus no beta-lactam antibiotics (Table 7).

\section{No conclusions possible: low- to very low-quality evidence}

Low-quality evidence in the Dodd 2013 review showed no clear difference for the presence of cerebral palsy at four years when prenatal administration of progesterone was compared with placebo for preventing preterm birth in women with a previous history of spontaneous preterm birth (RR $0.14,95 \% \mathrm{Cl} 0.01$ to 3.48 ; one trial; 274 children; Table 6). A subgroup analysis was planned for this outcome based on route of administration, however, only one trial was included, which used intramuscular administration (Table 7).

Low-quality evidence in the Neilson 2014 review showed no clear difference for the presence of cerebral palsy in children at 18 months when betamimetics were compared with placebo for inhibiting preterm labour (RR $0.19,95 \% \mathrm{Cl} 0.02$ to 1.63; one trial; 246 children; Table 6).

Very-low quality evidence in the Crowther 2014 review showed no clear difference for the presence of cerebral palsy in children at 
18 months when magnesium sulphate was compared with other tocolytic agents for preventing preterm birth in threatened preterm labour (RR 0.13, 95\% Cl 0.01 to 2.51; one trial; 106 children; Table 6).

Very low-quality evidence in the Crowther 2014 review also showed no clear difference for serious infant outcomes (including cerebral palsy) when magnesium sulphate was compared with other tocolytic agents for preventing preterm birth in threatened preterm labour (RR 2.47, $95 \% \mathrm{Cl} 0.69$ to 8.81 ; one trial; 106 children; Table 10).

There was also low-quality evidence in the Dodd 2013 review showing no clear difference in motor impairment for children at four years when prenatal administration of progesterone was compared with placebo for preventing preterm birth in women with a previous history of spontaneous preterm birth (RR $0.64,95 \% \mathrm{Cl}$ 0.11 to 3.76 ; one trial; 274 children; Table 11 ).

\section{Interventions prior to preterm birth for fetal maturation or neuroprotection}

\section{Effective interventions: high-quality evidence of effectiveness}

High-quality evidence in the Doyle 2009 review showed a reduction in cerebral palsy at 18 months to two years for children born to women at risk of preterm birth who received magnesium sulphate compared with placebo for neuroprotection of the fetus (RR 0.68 , $95 \% \mathrm{Cl} 0.54$ to 0.87 ; five trials; 6145 children; Table 6). Subgroup analyses for cerebral palsy based on intent (neuroprotective, preeclampsia, tocolytic), single or multiple pregnancy, gestational age at randomisation, loading dose, maintenance dose, and whether re-treatment was permitted, showed no clear subgroup differences (Table 7); the results did not substantially change when they only included studies with high antenatal corticosteroid use, nor when they performed a sensitivity analysis based on trial quality (Table 7).

High-quality evidence from Doyle 2009 review also showed a reduction in moderate to severe cerebral palsy at two years (RR $0.64,95 \% \mathrm{Cl} 0.44$ to 0.92 ; three trials; 4387 children; Table 9), and in substantial gross motor dysfunction at 18 months to two years (RR 0.61, 95\% Cl 0.44 to 0.85; four trials; 5980 children; Table 11); though no clear differences were shown for death or cerebral palsy at 18 months to two years (average RR $0.94,95 \% \mathrm{Cl} 0.78$ to 1.12 five trials; 6145 children; Table 8), any neurologic impairment at 18 months to two years (RR 1.01, 95\% Cl 0.86 to 1.19; two trials; 2848 children; Table 10), death or any neurologic impairment (composite outcomes that included cerebral palsy) at 18 months to two years (RR $1.00,95 \% \mathrm{Cl} 0.91$ to 1.11; two trials; 2848 children; Table 10), or death or major neurological disability at 18 months to two years (RR 1.02, $95 \% \mathrm{Cl} 0.90$ to 1.15; two trials; 2848 children; Table 10).

Moderate-quality evidence from Doyle 2009 showed no clear differences for mild cerebral palsy at two years (RR $0.74,95 \% \mathrm{Cl}$ 0.52 to 1.04; three trials; 4387 children; Table 9), moderate cerebral palsy at two years (RR $0.66,95 \% \mathrm{Cl} 0.34$ to 1.28 ; two trials; 1943 children; Table 9), severe cerebral palsy at two years (RR 0.82, 95\% $\mathrm{Cl} 0.37$ to 1.82; two trials; 1943 children; Table 9), major neurological disability at 18 months or two years (RR $1.07 ; 95 \% \mathrm{Cl} 0.82$ to 1.40 ; two trials, 2848 children) (Table 10), or death or substantial gross motor dysfunction for children at 18 months to two years (average RR $0.92,95 \% \mathrm{Cl} 0.75$ to 1.12 ; four trials; 5980 children; Table 11) when magnesium sulphate was compared with placebo for women at risk of preterm birth for neuroprotection of the fetus.
Probably ineffective interventions: moderate-quality evidence of lack of effectiveness

Moderate-quality evidence in the Crowther 2015 review showed no clear difference in cerebral palsy at 18 months to three years when repeat doses of corticosteroids were compared with a single course for women at risk of preterm birth (RR 1.03, 95\% Cl 0.71 to 1.50 ; four trials; 3800 children; Table 6).

High-quality evidence from the Crowther 2015 review also showed no clear differences for survival free of any disability at 18 months to two years (RR 1.01, 95\% Cl 0.97 to 1.05; two trials; 3155 children; Table 10), disability at two years (RR $0.98,95 \% \mathrm{Cl} 0.83$ to 1.16 ; one trial; 999 children; Table 10), or composite serious outcome at 18 months to two years (RR $0.99,95 \% \mathrm{Cl} 0.87$ to 1.12 ; two trials; 3164 children; Table 10) when repeat doses of corticosteroids were compared with a single course for women at risk of preterm birth;

Low-quality evidence from Crowther 2015 showed no clear differences for survival free of major neurosensory disability (a composite outcome that included cerebral palsy) for children at two to three years (average RR 1.01, 95\% Cl 0.92 to 1.11; two trials; 1317 children; Table 10) and major neurosensory disability at two to three years (average RR 1.08, 95\% Cl 0.31, 3.76; two trials; 1256 children; Table 10) when repeat doses of corticosteroids were compared with a single course for women at risk of preterm birth.

\section{No conclusions possible: low- to very low-quality evidence}

Low-quality evidence in the Crowther 2010a review, showed no clear difference in the presence of cerebral palsy in early childhood (between 18 months and three years) when phenobarbital was compared with placebo or no treatment, and given prior to preterm birth to prevent neonatal periventricular haemorrhage (RR 0.71, $95 \% \mathrm{Cl} 0.40$ to 1.28; two trials; 517 children; Table 6). Crowther 2010a had planned to conduct a sensitivity analysis, excluding trials with inadequate concealment of allocation of treatment; the results did not change as the one included trial was retained in the analysis (Table 7).

Very low-quality evidence in the Crowther 2010a review also showed no clear difference in other neuromotor impairment for children at three years when phenobarbital was compared with no treatment prior to preterm birth for preventing neonatal periventricular haemorrhage ( $\mathrm{RR} 0.67,95 \% \mathrm{Cl} 0.13$ to 3.49 ; one trial; 96 children; Table 11).

Very low-quality evidence from two reviews, showed no clear difference in the presence of cerebral palsy in mid-childhood (at seven years) when vitamin $\mathrm{K}$ was compared with placebo prior to preterm birth for preventing neonatal periventricular haemorrhage (Crowther 2010), and when phenobarbital was compared with placebo prior to preterm birth for preventing neonatal periventricular haemorrhage (Crowther 2010a; RR 0.77, $95 \% \mathrm{Cl} 0.33$ to 1.76; one trial; 299 children; Table 6). These two reviews included the same trial (which assessed a combination intervention), and made similar judgements regarding trial quality. Both reviews planned to conduct a sensitivity analysis excluding trials with inadequate concealment of allocation of treatment; the results did not change as the one included trial was retained in the analysis (Table 7).

Low-quality evidence in the Roberts 2006 review showed a possible reduction in cerebral palsy between two and six years for children 
born to women at risk of preterm birth who received antenatal corticosteroids compared with placebo for accelerating fetal lung maturation (RR $0.60 ;, 95 \% \mathrm{Cl} 0.34$ to 1.03; five trials; 904 children; Table 6). A subgroup analysis for cerebral palsy, based on decade of recruitment, revealed no clear subgroup differences (Table 7).

Very low-quality evidence from Roberts 2006 review also showed no clear difference in neurodevelopmental delay at two years when antenatal corticosteroids were compared with placebo for accelerating fetal lung maturation for women at risk of preterm birth (RR $0.64,95 \% \mathrm{Cl} 0.14$ to 2.98; one trial; 82 children; Table 10).

\section{Interventions for the management of preterm fetal compromise}

\section{Probably ineffective interventions: moderate-quality evidence of harm}

Moderate-quality evidence in the Stock 2016 review showed an increase in cerebral palsy at or after two years for children, who as preterm babies with suspected fetal compromise,were born immediately, compared with those for whom birth was deferred (RR 5.88, $95 \% \mathrm{Cl} 1.33$ to 26.02 ; one trial; 507 children; Table 6).

Low-quality evidence from the Stock 2016 review also showed no clear differences in death or disability at or after two years (RR 1.22, 95\% Cl 0.85 to 1.75; one trial; 573 children; Table 10), neurodevelopmental impairment at or after two years (RR 1.72, $95 \% \mathrm{Cl} 0.86$ to 3.41 ; one trial; 507 children; Table 10), or death or severe disability at six to 13 years (RR $0.82,95 \% \mathrm{Cl} 0.48$ to 1.40 ; one trial; 302 children; Table 10) when immediate delivery of the preterm baby with suspected fetal compromise was compared with deferred delivery.

\section{DISCUSSION}

\section{Summary of main results}

This overview included 15 Cochrane reviews, involving 279 randomised controlled trials and 101,098 children. Data for cerebral palsy were available from $27(10 \%)$ randomised controlled trials involving 32,490 (32\%) children.

Effective interventions: high-quality evidence of effectiveness: high-quality evidence showed a reduction in cerebral palsy for children born to women at risk of preterm birth who received magnesium sulphate compared with placebo for neuroprotection of the fetus.

Probably ineffective interventions: moderate-quality evidence of harm: moderate-quality evidence showed an increase in cerebral palsy for children born to mothers who received any prophylactic antibiotics versus no antibiotics for inhibiting preterm labour with intact membranes. Moderate-quality evidence also showed an increase in cerebral palsy for children who, as preterm babies with suspected fetal compromise, were born immediately compared with those for whom birth was deferred.

Probably ineffective interventions: moderate-quality evidence of lack of effectiveness: moderate-quality evidence showed no clear difference in cerebral palsy when repeat doses of corticosteroids were compared with a single course for women at risk of preterm birth.

\section{No conclusions possible: low- to very low-quality evidence:}

- Low-quality evidence showed a possible reduction in cerebral palsy for children born to women at risk of preterm birth who received antenatal corticosteroids compared with placebo for accelerating fetal lung maturation.

- Low-quality evidence showed no clear difference for cerebral palsy with interventionist care versus expectant care for severe pre-eclampsia; magnesium sulphate versus placebo for preeclampsia; continuous cardiotocography versus intermittent auscultation for fetal assessment during labour; prenatal progesterone versus placebo for preventing preterm birth; and betamimetics versus placebo for inhibiting preterm labour.

- Very low-quality evidence showed no clear difference for cerebral palsy with any antihypertensive drug versus placebo, or with an oral beta-blocker versus placebo for mild to moderate hypertension; with magnesium sulphate versus other tocolytic agents for preventing preterm birth; and with vitamin $\mathrm{K}$ and phenobarbital versus placebo prior to preterm birth for preventing neonatal periventricular haemorrhage.

\section{Overall completeness and applicability of evidence}

This overview summarises published Cochrane reviews assessing antenatal and intrapartum interventions and their effects on cerebral palsy. Interventions in the neonatal period are the focus of a companion overview (Shepherd 2016).

We were only able to include 15 reviews (representing less than 3\% of the 546 Pregnancy and Childbirth reviews in the Cochrane Database of Systematic Reviews), which reported data on our primary outcome, cerebral palsy. We identified an additional nine protocols that have pre-specified cerebral palsy as a primary or secondary outcome and will be considered for inclusion in future updates of the overview when they are published as full reviews. These protocols plan to assess a variety of interventions including: interventions for treating hypertension (guided imagery), preventing (with melatonin) or treating pre-eclampsia (melatonin; epidural therapy; planned caesarean section versus planned vaginal delivery), for preventing preterm labour or birth (progestogens for multiple pregnancy; hypnosis), for diagnosing and preventing fetal compromise in labour (intermittent auscultation of fetal heart rate in labour), and for induction of labour (amniotomy plus intravenous oxytocin). See Appendix 1, Ongoing reviews. We were unable to include an additional 62 reviews assessing a wide range of antenatal and intrapartum interventions, because although they recognised the potential impact of the interventions of interest on cerebral palsy (through pre-specifying cerebral palsy as a review outcome), none of the included trials within these reviews reported on this outcome. We have summarised the main conclusions of these reviews in Appendix 2, Reviews awaiting further classification, and will again consider them for inclusion in future updates of the overview.

Although the 15 reviews in this overview included 279 randomised trials, involving over 101,098 women and their babies, the body of evidence for our review was substantially reduced because the included reviews (and trials) did not report on our outcomes of interest. For our primary outcome, cerebral palsy, we have included data from all 15 reviews, but from 27 randomised trials, or only $10 \%$ of the trials within the included reviews.

The body of evidence for our secondary outcomes was further reduced, with six reviews reporting data on a composite outcome 
including cerebral palsy, three on motor dysfunction, two on severity of cerebral palsy, and one of the 15 reviews reporting data on cerebral palsy or death. None of our included reviews reported specifically on the type of cerebral palsy. For the majority of our outcomes, data were reported in the reviews by only one or two trials, up to a maximum of five trials, for the majority of interventions assessed. Thus, there were too few data to reach firm conclusions on the effects on cerebral palsy and our secondary outcomes. Unsurprisingly, for the majority of the reviews, data related to cerebral palsy was commonly shorter-term (reported at one to two years of age), with longer-term follow up less commonly reported (only three reviews reported on cerebral palsy at seven years). Definitions or criteria for a diagnosis of cerebral palsy, where reported, and assessment methods, varied substantially between and within trials; often this information was not reported in the reviews.

We did not attempt to make indirect comparisons in order to address questions concerning the relative performance of difference antenatal or intrapartum interventions. This would not have been appropriate, due to the variety of interventions (and control conditions) assessed in different populations, for various indications. Rather, we aimed to systematically consider all potentially relevant interventions for their ability to contribute to the prevention of cerebral palsy. Within this overview, we have not attempted to duplicate details of participants, interventions (and control conditions) in individual trials. Consulting the individual reviews and trials is encouraged to obtain more information on these factors.

The scope of this overview was limited to effects of interventions on cerebral palsy, and a restricted number of pre-specified secondary outcomes, including the composite outcome 'cerebral palsy or death', in recognition of the competing risks of death and survival with neurosensory disability. In order to assess the effects (benefits or harms) of the included interventions on other outcomes (including perinatal death), readers are encouraged to refer to the included Cochrane reviews themselves. For example, while this overview showed low-quality evidence of a possible reduction in cerebral palsy for children born to women at risk of preterm birth who received antenatal corticosteroids for accelerating fetal lung maturation, the recently updated Roberts 2017 review assessed additional outcomes, and has revealed reductions in perinatal death, neonatal death, respiratory distress syndrome, moderate to severe respiratory distress syndrome, intraventricular haemorrhage, necrotising enterocolitis, need for mechanical ventilation, and systemic infections in the first 48 hours of life. The review concluded that the findings support "the continued use of a single course of antenatal corticosteroids to accelerate fetal lung maturation in women at risk of preterm birth" (Roberts 2017).

\section{Quality of the evidence}

All of the included reviews were assessed to be of high quality and at low risk of bias with the AMSTAR and ROBIS tools (Table 4; Table 5). Although the two tools differ in their approaches to assessing review quality or risk of bias, they led to similar assessments. All of the reviews assessed the risk of bias of the included randomised trials, the majority using current guidance as outlined in Chapter 8 of the Cochrane Handbook for Systematic Reviews of Interventions (Higgins 2011). The quality of the randomised trials was variable within and between the reviews (Table 3 ).
Two of the 15 reviews used the GRADE approach to assess the quality of evidence for review outcomes (Alfirevic 2013; Stock 2016). For the other reviews, we used the GRADE system to rate the quality of evidence, incorporating the assessments of study limitations (risk of bias) reported by the review authors. For our primary outcome, cerebral palsy, the quality of the evidence ranged from very low to high, similarly for our secondary outcomes. Downgrading of the quality was most commonly due to study limitations (risk of bias), and imprecision (small sample sizes, low number of events, and wide confidence intervals). As our overview outcomes were assessed through longer-term follow-up of antenatal or intrapartum interventions, the potential for bias relating to attrition (which could occur due to children lost to follow-up differing systematically from those followed-up), was an important consideration when rating the quality of evidence. The summary of findings for the quality of evidence for each outcome are set out in Table 6: Cerebral palsy; Table 8: Cerebral palsy or death; Table 9: Severity of cerebral palsy; Table 10: Other composite outcomes that include cerebral palsy as a component; and Table 11: Motor dysfunction.

\section{Potential biases in the overview process}

We were aware that there were risks of introducing bias at all stages of the overview process, and took a number of steps to minimise this. All included Cochrane reviews used a protocol that aimed to minimise bias; we also developed a protocol for our overview. At least two overview authors independently assessed reviews for inclusion, carried out data extraction and quality assessment, and assessed the quality of the evidence using the GRADE approach. One potential source of bias relates to authors of this overview being authors of some of the included reviews. As pre-specified in our protocol, data extraction and quality assessment for these reviews were carried out by two overview authors who were not authors of the individual reviews.

We undertook a comprehensive search of the Cochrane Database of Systematic Reviews without language or date restrictions, and identified published reviews, as well as planned and ongoing reviews (protocols). We did not search other databases, and thus it is possible that non-Cochrane systematic reviews assessing antenatal and intrapartum interventions, and reporting on cerebral palsy, have been conducted but not identified. It is also possible that Cochrane reviews assessing interventions that could have potential to impact cerebral palsy risk (see Description of the interventions for further discussion of various interventions) may not have acknowledged this by including cerebral palsy as a review outcome. Thus, data from relevant randomised trials assessing these interventions would not have been identified and included in this overview. Based on our search strategy, even Cochrane reviews that pre-specified outcomes such as 'impaired long-term growth and development in infancy and childhood' (e.g. Abalos 2014), but subsequently reported specifically on 'cerebral palsy' have been captured in our search, and included. However, reviews that reported on long-term neurodevelopmental outcomes without any mention of 'cerebral palsy' would not have been identified, which highlights the need for all Cochrane reviews to provide clear definitions accompanying any outcome measures reported.

While our included reviews were judged to be of high methodological quality and at low risk of bias, not all were considered 'up-to-date', with only one third conducting searches in the past four years; similarly, not all of the 'Reviews awaiting 
further classification' were 'up-to-date'. Thus, it is possible that additional trials assessing antenatal and intrapartum interventions and reporting on cerebral palsy have been published, but not yet included in the relevant Cochrane reviews; it is also possible that additional trials have been conducted but are not yet published. If and when such trials are included in the relevant Cochrane review, they will be incorporated into this overview.

\section{Agreements and disagreements with other studies or reviews}

We did not identify any other overviews or systematic reviews specifically designed to assess antenatal and intrapartum interventions for preventing cerebral palsy.

In regards to cerebral palsy prevention for children born preterm, World Health Organization (WHO) recommendations focused on improving the outcomes of preterm birth have recently been released, based on up-to-date systematic reviews for priority questions (WHO 2015). These guidelines assessed a number of interventions that were included in this review, and reached similar conclusions. Specifically, a strong recommendation was made for the use of magnesium sulphate for women at risk of imminent preterm birth before 32 weeks of gestation for prevention of cerebral palsy in the infant and child, which was based on which was based on high quality evidence for cerebral palsy. A strong recommendation was also made against the use of routine antibiotic administration for women in preterm labour with intact amniotic membranes and no clinical signs of infection, based on moderate-quality evidence for cerebral palsy (WHO 2015).

McIntyre 2013 conducted a systematic review of cohort and casecontrol studies focused on identifying risk factors for cerebral palsy in children born at term, with an aim to assess whether the potential for prevention of these risk factors has been adequately explored. They identified antenatal risk factors that included placental dysfunction or abnormalities, major and minor birth defects and low birthweight, while intrapartum risk factors were meconium aspiration, caesarean section, vacuum or breech delivery. Strategies for possible prevention of cerebral palsy in children born at term were only recognised to currently exist for two of these risk factors: reducing low birthweight (reducing heavy alcohol consumption during pregnancy), and reducing meconium aspiration (amnioinfusion in settings with limited perinatal surveillance; curtailment of post-term pregnancy). This review highlighted that prevention strategies for cerebral palsy in term born infants are urgently required, and called for heightened efforts focused on preventing identified risk factors, and thus, interrupting pathways to cerebral palsy.

A systematic review by Hines 2015 was designed to systematically review meta-analyses and randomised trials of interventions for infants at risk of cerebral palsy, to determine if consensus existed in study endpoints. The review identified that of the 685 Cochrane Pregnancy and Childbirth or Neonatal reviews published at the time, 177 addressed acknowledged risk factors for cerebral palsy (such as preterm birth, pre-eclampsia, or neonatal infection). A sample of 22 reviews, with 165 included randomised trials were selected, which addressed interventions such as fetal monitoring during labour; preventing preterm labour, hypertension, and pre-eclampsia; timing of umbilical cord clamping; maternal or neonatal infection, or both; minimising permanent brain injury; infant respiratory function; and glutamine supplementation. Hines 2015 identified that of the 22 reviews, 18 specified neurodevelopmental outcomes, such as cerebral palsy, blindness, deafness, or intellectual impairment, but of the 203 relevant randomised trials in those reviews, only $22(11 \%)$ contributed data to meta-analyses for these outcomes. Similar to our overview, Hines 2015 identified an urgent need for long-term follow-up after such antenatal and intrapartum interventions, and concluded that "Variation in outcome measurement and long-term follow-up has hampered the ability of RCTs to contribute data on important outcomes for $\mathrm{CP}$, resulting in lost opportunities to measure the impact of maternal and neonatal interventions".

\section{AUTHORS' CONCLUSIONS}

\section{Implications for practice}

This overview summarises the evidence from Cochrane reviews of randomised controlled trials regarding the effects of antenatal and intrapartum intervention on cerebral palsy, and can be used by researchers, funding bodies, policy makers, clinicians, and consumers to aid decision-making and evidence translation.

There is high-quality evidence that magnesium sulphate for neuroprotection of the fetus, given to women at risk of preterm birth, can prevent cerebral palsy better than placebo. Moderatequality evidence shows that any prophylactic antibiotics for women in preterm labour with intact membranes may increase the risk of cerebral palsy more than no antibiotics. Moderatequality evidence shows that immediate birth of preterm babies with suspected fetal compromise may increase the risk of cerebral palsy more than deferred birth. There is moderate-quality evidence showing no clear difference in the risk of cerebral palsy between repeat doses of corticosteroids and a single course for women at risk of preterm birth. No conclusions were possible for other interventions assessed in this overview, because of low- to very-low quality evidence.

The scope of this overview was limited to the effects of interventions on cerebral palsy, and pre-specified secondary review outcomes. Consultation of the included Cochrane reviews is required to formally assess additional benefits and harms of these interventions, including impacts on risk factors for cerebral palsy, (such as the reduction in intraventricular haemorrhage for preterm babies following exposure to antenatal corticosteroids).

\section{Implications for research}

This overview highlights areas where there was insufficient evidence to draw conclusions on the effects of several antenatal and intrapartum interventions on cerebral palsy, and it should be used to generate research questions and priorities. As cerebral palsy is rarely diagnosed at birth, has diverse risk and causal factors, and is diagnosed in approximately one in 500 children, it is a challenging outcome for investigators of such interventions to measure and report. To date, a small proportion of Cochrane reviews assessing antenatal and intrapartum interventions have been able to report on cerebral palsy, which may be due to a number of reasons, including: a lack of primary research (with few randomised trials of antenatal and intrapartum interventions conducting long-term follow-up of children), lack of reporting on cerebral palsy by randomised trials, lack of reporting on cerebral palsy by relevant Cochrane reviews (due to not pre-specifying it as an outcome of interest, not clearly defining long-term follow- 
up results, or not being 'up-to-date'), or the absence of Cochrane reviews assessing relevant interventions.

With greater understanding of the diverse risk factors and causes of cerebral palsy, there is an urgent need for long-term follow-up of interventions addressing risk factors for cerebral palsy, as well as a need to consider the use of relatively new interim assessments (such as the General Movements Assessment), to measure impact on cerebral palsy. Such studies must be rigorous in their design, and aim for consistency in cerebral palsy outcome measurement and reporting to facilitate pooling of outcome data, therefore, informing research efforts aimed at prevention of cerebral palsy.

\section{ACKNOWLEDGEMENTS}

We thank the Cochrane Pregnancy and Childbirth Editorial Base for their support.
We thank the Cerebral Palsy Alliance Research Foundation Australia for funding this project.

This project was also supported by the National Institute for Health Research, via Cochrane Infrastructure funding to Cochrane Pregnancy and Childbirth. The views and opinions expressed therein are those of the authors and do not necessarily reflect those of the Systematic Reviews Programme, NIHR, NHS or the Department of Health.

As part of the pre-publication editorial process, this review has been commented on by two peers (an editor and referee who is external to the editorial team), a member of Cochrane Pregnancy and Childbirth's international panel of consumers and the Group's Statistical Adviser. 


\section{RE F E R E N C E S}

\section{References to included reviews}

\section{Abalos 2014}

Abalos E, Duley L, Steyn DW. Antihypertensive drug therapy for mild to moderate hypertension during pregnancy. Cochrane Database of Systematic Reviews 2014, Issue 2. [DOI: 10.1002/14651858.CD002252.pub3]

\section{Alfirevic 2013}

Alfirevic Z, Devane D, Gyte GML. Continuous cardiotocography (CTG) as a form of electronic fetal monitoring (EFM) for fetal assessment during labour. Cochrane Database of Systematic Reviews 2013, Issue 5. [DOI: 10.1002/14651858.CD006066.pub2]

\section{Churchill 2013}

Churchill D, Duley L, Thornton JG, Jones L. Interventionist versus expectant care for severe pre-eclampsia between 24 and 34 weeks' gestation. Cochrane Database of Systematic Reviews 2013, Issue 7. [DOI: 10.1002/14651858.CD003106.pub2]

\section{Crowther 2010}

Crowther CA, Crosby DD. Vitamin K prior to preterm birth for preventing neonatal periventricular haemorrhage. Cochrane Database of Systematic Reviews 2010, Issue 1. [DOI: 10.1002/14651858.CD000229.pub2]

\section{Crowther 2010a}

Crowther CA, Crosby DD. Phenobarbital prior to preterm birth for preventing neonatal periventricular haemorrhage. Cochrane Database of Systematic Reviews 2010, Issue 1. [DOI: 10.1002/14651858.CD000164.pub2]

\section{Crowther 2014}

Crowther CA, Brown J, McKinlay CJD, Middleton P. Magnesium sulphate for preventing preterm birth in threatened preterm labour. Cochrane Database of Systematic Reviews 2014, Issue 8. [DOI: 10.1002/14651858.CD001060.pub2]

\section{Crowther 2015}

Crowther CA, McKinlay CJD, Middleton P, Harding JE. Repeat doses of prenatal corticosteroids for women at risk of preterm birth for improving neonatal health outcomes. Cochrane Database of Systematic Reviews 2015, Issue 7. [DOI: 10.1002/14651858.CD003935.pub4]

\section{Dodd 2013}

Dodd JM, Jones L, Flenady V, Cincotta R, Crowther CA. Prenatal administration of progesterone for preventing preterm birth in women considered to be at risk of preterm birth. Cochrane Database of Systematic Reviews 2013, Issue 7. [DOI: 10.1002/14651858.CD004947.pub3]

\section{Doyle 2009}

Doyle LW, Crowther CA, Middleton P, Marret S, Rouse D. Magnesium sulphate for women at risk of preterm birth for neuroprotection of the fetus. Cochrane Database of Systematic Reviews 2009, Issue 1. [DOI: 10.1002/14651858.CD004661.pub3]

\section{Duley 2010}

Duley L, Gülmezoglu AM, Henderson-Smart DJ, Chou D. Magnesium sulphate and other anticonvulsants for women with pre-eclampsia. Cochrane Database of Systematic Reviews 2010, Issue 11. [DOI: 10.1002/14651858.CD000025.pub2]

\section{Flenady 2013}

Flenady V, Hawley G, Stock OM, Kenyon S, Badawi N. Prophylactic antibiotics for inhibiting preterm labour with intact membranes. Cochrane Database of Systematic Reviews 2013, Issue 12. [DOI: 10.1002/14651858.CD000246.pub2]

\section{Magee 2003}

Magee L, Duley L. Oral beta-blockers for mild to moderate hypertension during pregnancy. Cochrane Database of Systematic Reviews 2003, Issue 3. [DOI: 10.1002/14651858.CD002863]

\section{Neilson 2014}

Neilson JP, West HM, Dowswell T. Betamimetics for inhibiting preterm labour. Cochrane Database of Systematic Reviews 2014, Issue 2. [DOI: 10.1002/14651858.CD004352.pub3]

\section{Roberts 2006}

Roberts D, Dalziel SR. Antenatal corticosteroids for accelerating fetal lung maturation for women at risk of preterm birth. Cochrane Database of Systematic Reviews 2006, Issue 3. [DOI: 10.1002/14651858.CD004454.pub2]

\section{Stock 2016}

Stock SJ, Bricker L, Norman JE. Immediate versus deferred delivery of the preterm baby with suspected fetal compromise for improving outcomes. Cochrane Database of Systematic Reviews 2016, Issue 7. [DOI: 10.1002/14651858.CD008968.pub3]

\section{References to excluded reviews}

\section{Abou El Senoun 2014}

Abou El Senoun G, Dowswell T, Mousa HA. Planned home versus hospital care for preterm prelabour rupture of the membranes (PPROM) prior to 37 weeks' gestation. Cochrane Database of Systematic Reviews 2014, Issue 4. [DOI: 10.1002/14651858.CD008053.pub3]

\section{Bricker 2015}

Bricker L, Medley N, Pratt JJ. Routine ultrasound in late pregnancy (after 24 weeks' gestation). Cochrane Database of Systematic Reviews 2015, Issue 6. [DOI: 10.1002/14651858.CD001451.pub4]

\section{Buchanan 2010}

Buchanan SL, Crowther CA, Levett KM, Middleton P, Morris J. Planned early birth versus expectant management for women with preterm prelabour rupture of membranes prior to 37 weeks' gestation for improving pregnancy outcome. Cochrane Database of Systematic Reviews 2010, Issue 3. [DOI: 10.1002/14651858.CD004735.pub3] 


\section{Chapman 2014}

Chapman E, Reveiz L, Illanes E, Bonfill Cosp X. Antibiotic regimens for management of intra-amniotic infection. Cochrane Database of Systematic Reviews 2014, Issue 12. [DOI: 10.1002/14651858.CD010976.pub2]

\section{Crowley 2016}

Crowley AE, Grivell RM, Dodd JM. Sealing procedures for preterm prelabour rupture of membranes. Cochrane Database of Systematic Reviews 2016, Issue 7. [DOI: 10.1002/14651858.CD010218.pub2]

\section{Dare 2006}

Dare MR, Middleton P, Crowther CA, Flenady V, Varatharaju B. Planned early birth versus expectant management (waiting) for prelabour rupture of membranes at term (37 weeks or more). Cochrane Database of Systematic Reviews 2006, Issue 1. [DOI: 10.1002/14651858.CD005302.pub2]

\section{East 2014}

East CE, Begg L, Colditz PB, Lau R. Fetal pulse oximetry for fetal assessment in labour. Cochrane Database of Systematic Reviews 2014, Issue 10. [DOI: 10.1002/14651858.CD004075.pub4]

\section{Gomi 2015}

Gomi H, Goto Y, Laopaiboon M, Usui R, Mori R. Routine blood cultures in the management of pyelonephritis in pregnancy for improving outcomes. Cochrane Database of Systematic Reviews 2015, Issue 2. [DOI: 10.1002/14651858.CD009216.pub2]

\section{Han 2013}

Han S, Crowther CA, Moore V. Magnesium maintenance therapy for preventing preterm birth after threatened preterm labour. Cochrane Database of Systematic Reviews 2013, Issue 5. [DOI: 10.1002/14651858.CD000940.pub3]

\section{Hofmeyr 2015}

Hofmeyr GJ, Barrett JF, Crowther CA. Planned caesarean section for women with a twin pregnancy. Cochrane Database of Systematic Reviews 2015, Issue 12. [DOI: 10.1002/14651858.CD006553.pub3]

\section{Hopkins 2002}

Hopkins L, Smaill FM. Antibiotic regimens for management of intra-amniotic infection. Cochrane Database of Systematic Reviews 2002, Issue 3. [DOI: 10.1002/14651858.CD003254]

\section{Kenyon 2013}

Kenyon S, Boulvain M, Neilson JP. Antibiotics for preterm rupture of membranes. Cochrane Database of Systematic Reviews 2013, Issue 12. [DOI: 10.1002/14651858.CD001058.pub3]

\section{Khunpradit 2011}

Khunpradit S, Lumbiganon P, Laopaiboon M. Admission tests other than cardiotocography for fetal assessment during labour. Cochrane Database of Systematic Reviews 2011, Issue 6. [DOI: 10.1002/14651858.CD008410.pub2]

\section{Kiiza 2015}

Kiiza JAK, Hofmeyr GJ. Amnioinfusion for chorioamnionitis. Cochrane Database of Systematic Reviews 2015, Issue 6. [DOI: 10.1002/14651858.CD011622]

\section{Lewin 2010}

Lewin S, Munabi-Babigumira S, Glenton C, Daniels K, Bosch-Capblanch X, Van Wyk BE, et al. Lay health workers in primary and community health care for maternal and child health and the management of infectious diseases. Cochrane Database of Systematic Reviews 2010, Issue 3. [DOI: 10.1002/14651858.CD004015.pub3]

\section{Lutomski 2015}

Lutomski JE, Meaney S, Greene RA, Ryan AC, Devane D. Expert systems for fetal assessment in labour. Cochrane Database of Systematic Reviews 2015, Issue 4. [DOI: 10.1002/14651858.CD010708.pub2]

\section{Mackeen 2014}

Mackeen AD, Seibel-Seamon J, Muhammad J, Baxter JK, Berghella V. Tocolytics for preterm premature rupture of membranes. Cochrane Database of Systematic Reviews 2014, Issue 2. [DOI: 10.1002/14651858.CD007062.pub3]

\section{Neilson 2003}

Neilson JP. Interventions for suspected placenta praevia. Cochrane Database of Systematic Reviews 2003, Issue 2. [DOI: 10.1002/14651858.CD001998]

\section{Olsen 2012}

Olsen O, Clausen JA. Planned hospital birth versus planned home birth. Cochrane Database of Systematic Reviews 2012, Issue 9. [DOI: 10.1002/14651858.CD000352.pub2]

\section{Othman 2007}

Othman M, Alfirevic Z, Neilson JP. Probiotics for preventing preterm labour. Cochrane Database of Systematic Reviews 2007, Issue 1. [DOI: 10.1002/14651858.CD005941.pub2]

\section{Sangkomkamhang 2015}

Sangkomkamhang US, Lumbiganon P, Prasertcharoensuk W, Laopaiboon M. Antenatal lower genital tract infection screening and treatment programs for preventing preterm delivery. Cochrane Database of Systematic Reviews 2015, Issue 2. [DOI: 10.1002/14651858.CD006178.pub3]

\section{Say 1996}

Say L, Gülmezoglu AM, Hofmeyr GJ. Transcutaneous electrostimulation for suspected placental insufficiency (diagnosed by Doppler studies). Cochrane Database of Systematic Reviews 1996, Issue 1. [DOI: 10.1002/14651858.CD000079]

\section{Say 1996a}

Say L, Gülmezoglu AM, Hofmeyr GJ. Plasma volume expansion for suspected impaired fetal growth. Cochrane Database of Systematic Reviews 1996, Issue 4. [DOI: 10.1002/14651858.CD000167] 


\section{Say 1996b}

Say L, Gülmezoglu AM, Hofmeyr GJ. Calcium channel blockers for potential impaired fetal growth. Cochrane Database of Systematic Reviews 1996, Issue 1. [DOI: 10.1002/14651858.CD000049]

\section{Say $1996 c$}

Say L, Gülmezoglu AM, Hofmeyr GJ. Bed rest in hospital for suspected impaired fetal growth. Cochrane Database of Systematic Reviews 1996, Issue 1. [DOI: 10.1002/14651858.CD000034]

\section{Say 2001}

Say L, Gülmezoglu AM, Hofmeyr GJ. Betamimetics for suspected impaired fetal growth. Cochrane Database of Systematic Reviews 2001, Issue 4. [DOI: 10.1002/14651858.CD000036]

\section{Say 2003}

Say L, Gülmezoglu AM, Hofmeyr GJ. Maternal oxygen administration for suspected impaired fetal growth. Cochrane Database of Systematic Reviews 2003, Issue 1. [DOI: 10.1002/14651858.CD000137]

\section{Say 2003a}

Say L, Gülmezoglu AM, Hofmeyr GJ. Maternal nutrient supplementation for suspected impaired fetal growth. Cochrane Database of Systematic Reviews 2003, Issue 1. [DOI: 10.1002/14651858.CD000148]

\section{Say 2003b}

Say L, Gülmezoglu AM, Hofmeyr GJ. Hormones for suspected impaired fetal growth. Cochrane Database of Systematic Reviews 2003, Issue 1. [DOI: 10.1002/14651858.CD000109]

\section{Siegfried 2011}

Siegfried N, Van der Merwe L, Brocklehurst P, Sint TT. Antiretrovirals for reducing the risk of mother-to-child transmission of HIV infection. Cochrane Database of Systematic Reviews 2011, Issue 7. [DOI: 10.1002/14651858.CD003510.pub3]

\section{Siriwachirachai 2014}

Siriwachirachai T, Sangkomkamhang US, Lumbiganon P, Laopaiboon M. Antibiotics for meconium-stained amniotic fluid in labour for preventing maternal and neonatal infections. Cochrane Database of Systematic Reviews 2014, Issue 11. [DOI: 10.1002/14651858.CD007772.pub3]

\section{Stan 2013}

Stan CM, Boulvain M, Pfister R, Hirsbrunner-Almagbaly P. Hydration for treatment of preterm labour. Cochrane Database of Systematic Reviews 2013, Issue 11. [DOI: 10.1002/14651858.CD003096.pub2]

\section{Thomas 2007}

Thomas JT, Muller P, Wilkinson CS. Antenatal phenobarbital for reducing neonatal jaundice after red cell isoimmunization. Cochrane Database of Systematic Reviews 2007, Issue 2. [DOI: 10.1002/14651858.CD005541.pub2]

\section{Additional references}

\section{Abdel-Latif 2010}

Abdel-Latif ME, Osborn DA, Challis D Cochrane Database of Systematic. Intra-amniotic surfactant for women at risk of preterm birth for preventing respiratory distress in newborns. Cochrane Database of Systematic Reviews 2010, Issue 1. [DOI: 10.1002/14651858.CD007916.pub2]

\section{Access Economics 2008}

Access Economics. The Economic Impact of Cerebral Palsy in Australia in 2007. Sydney: Cerebral Palsy Australia, 2008.

\section{ACPR Group 2013}

Australian Cerebral Palsy Register (ACPR) Group. Report of the Australian Cerebral Palsy Register, Birth Years 1993-2006. Sydney: ACPR Group, 2013.

\section{Amorim 2011}

Amorim MMR, Souza ASR, Katz L, Noronha Neto C. Planned caesarean section versus planned vaginal delivery for severe preeclampsia. Cochrane Database of Systematic Reviews 2011, Issue 11. [DOI: 10.1002/14651858.CD009430]

\section{Badawi 2013}

Badawi N, Keogh JM. Causal pathways in cerebral palsy. Journal of Paediatrics and Child Health 2013;49(1):5-8.

\section{Bax 1964}

Bax MCO. Terminology and classification of cerebral palsy. Developmental Medicine \& Child Neurology 1964;6(3):295-7.

\section{Blair 1988}

Blair E, Stanley FJ. Intrapartum asphyxia: a rare cause of cerebral palsy. Journal of Pediatrics 1988;112(4):515-9.

\section{Blair 2001}

Blair E, Watson L, Badawi N, Stanley FJ. Life expectancy among people with cerebral palsy in Western Australia. Developmenta Medicine \& Child Neurology 2001;43(8):508-15.

\section{Blair 2006}

Blair E, Watson L. Epidemiology of cerebral palsy. Seminars in Fetal and Neonatal Medicine 2006;11:117-25.

\section{Bosanquet 2013}

Bosanquet M, Copeland L, Ware R, Boyd R. A systematic review of tests to predict cerebral palsy in young children. Developmental Medicine and Child Neurology 2013;55(5):418-26.

\section{Cans 2000}

Cans C. Surveillance of cerebral palsy in Europe: a collaboration of cerebral palsy surveys and registers. Developmental Medicine \& Child Neurology 2000;42(12):816-24.

\section{CDC 2004}

Centers for Disease Control and Prevention (CDC). Economic costs associated with mental retardation, cerebral palsy, hearing loss, and vision impairment - United States, 2003. MMWR: Morbidity and Mortality Weekly Report 2004;53(3):57-9. 


\section{Chang 2015}

Chang E. Preterm birth and the role of neuroprotection. BMJ 2015;350:g6661.

\section{Colver 2012}

Colver A. Outcomes for people with cerebral palsy: life expectancy and quality of life. Paediatrics and Child Health 2012;22(9):384-7.

\section{Colver 2014}

Colver A, Fairhurst C, Pharoah PO. Cerebral palsy. Lancet 2014;383:1240-9.

\section{Compagnone 2014}

Compagnone E, Maniglio J, Camposeo S, Vespino T, Losito L, De Rinaldis M, et al. Functional classifications for cerebral palsy: correlations between the gross motor function classification system (GMFCS), the manual ability classification system (MACS) and the communication function classification system (CFCS). Research in Developmental Disabilities 2014;35(11):2651-7.

\section{Covidence 2015 [Computer program]}

Veritas Health Innovation. Covidence. Version accessed 17 May 2015. Melbourne, Australia: Veritas Health Innovation, 2015.

\section{Davis 2010}

Davis E, Shelley A, Waters E, Boyd R, Cook K, Davern M. The impact of caring for a child with cerebral palsy: quality of life for mothers and fathers. Child: Care, Health and Development 2010;36:63-73.

\section{Eliasson 2006}

Eliasson AC, Krumlinde-Sundholm L, Rösblad B, Beckung E, Arner M, Ohrvall AM, et al. The Manual Ability Classification System (MACS) for children with cerebral palsy: scale development and evidence of validity and reliability. Developmental Medicine \& Child Neurology 2006;48:549-54.

\section{Ellenberg 2013}

Ellenberg JH, Nelson KB. The association of cerebral palsy with birth asphyxia: a definitional quagmire. Developmental Medicine \& Child Neurology 2013;55:210-6.

\section{Farquhar 2015}

Farquhar C, Rishworth JR, Brown J, Nelen WLDM, Marjoribanks J. Assisted reproductive technology: an overview of Cochrane Reviews. Cochrane Database of Systematic Reviews 2015, Issue 7. [DOI: 10.1002/14651858.CD010537.pub4]

\section{GRADEpro GDT 2015 [Computer program]}

McMaster University (developed by Evidence Prime). GRADEpro GDT. Hamilton (ON): McMaster University (developed by Evidence Prime), 2015.

\section{Hemming 2005}

Hemming K, Hutton JL, Colver A, Platt M-J. Regional variation in survival of people with cerebral palsy in the United Kingdom. Pediatrics 2005;116(6):1383-90.

\section{Hidecker 2011}

Hidecker MJC, Paneth N, Rosenbaum PL, Kent RD, Lillie J, Eulenberg JB, et al. Developing and validating the Communication Function Classification System for individuals with cerebral palsy. Developmental Medicine \& Child Neurology 2011;53(8):704-10.

\section{Hidecker 2012}

Hidecker MJ, Ho NT, Dodge N, Hurvitz EA, Slaughter J, Workinger MS, et al. Inter-relationships of functional status in cerebral palsy: analyzing gross motor function, manual ability, and communication function classification systems in children. Developmental Medicine and Child Neurology 2012;54(8):737-42.

\section{Higgins 2011}

Higgins JPT, Green S, editors. Cochrane Handbook for Systematic Reviews of Interventions Version 5.1.0 (updated March 2011). The Cochrane Collaboration, 2011. Available from www.handbook.cochrane.org.

\section{Himpens 2008}

Himpens E, Van den Broeck C, Oostra A, Calders P, Vanhaesebrouck P. Prevalence, type, distribution, and severity of cerebral palsy in relation to gestational age: a metaanalytic review. Developmental Medicine and Child Neurology 2008;50:334-40.

\section{Hines 2015}

Hines M, Swinburn K, Mclntyre S, Novak I, Badawi N. Infants at risk of cerebral palsy: a systematic review of outcomes used in Cochrane studies of pregnancy, childbirth and neonatology. Journal of Maternal-Fetal \& Neonatal Medicine 2015;28(16):1871-83.

\section{Howard 2005}

Howard J, Soo B, Graham HK, Boyd RN, Reid S, Lanigan A, et al. Cerebral palsy in Victoria: motor types, topography and gross motor function. Journal of Paediatrics and Child Health 2005;41(9-10):479-83.

\section{lams 2008}

lams JD, Romero R, Culhane JF, Goldenberg RL. Preterm birth 2 - Primary, secondary, and tertiary interventions to reduce the morbidity and mortality of preterm birth. Lancet 2008;371(9607):164-75.

\section{IMPACT for CP 2011}

IMPACT for Cerebral Palsy. 2011 Summit Report. Availale from impact.cerebralpalsy.org.au/activities/research-summits/2011summit-report/ (accessed 17 May 2015).

\section{Inder $\mathbf{2 0 0 0}$}

Inder TE, Volpe JJ. Mechanisms of perinatal brain injury. Seminars in Neonatology 2000;5:3-16.

\section{Jacobs 2013}

Jacobs SE, Berg M, Hunt R, Tarnow-Mordi WO, Inder TE, Davis PG. Cooling for newborns with hypoxic ischaemic encephalopathy. Cochrane Database of Systematic Reviews 2013, Issue 1. [DOI: 10.1002/14651858.CD003311.pub3] 


\section{Jacobsson 2004}

Jacobsson B, Hagberg G. Antenatal risk factors for cerebral palsy. Best Practice \& Research. Clinical Obstetrics \& Gynaecology 2004;18(3):425-36.

\section{Jones 2012}

Jones L, Othman M, Dowswell T, Alfirevic Z, Gates S, Newburn $M$, et al. Pain management for women in labour: an overview of systematic reviews. Cochrane Database of Systematic Reviews 2012, Issue 3. [DOI: 10.1002/14651858.CD009234.pub2]

\section{Kruse 2009}

Kruse M, Michelsen SI, Flachs EM, Brønnum-Hansen H, Madsen M, Uldall P. Lifetime costs of cerebral palsy. Developmental Medicine \& Child Neurology 2009;51(8):622-8.

\section{Lagunju 2009}

Lagunju IA, Fatunde OJ. The child with cerebral palsy in a developing country - diagnosis and beyond. Journal of Pediatric Neurology 2009;7:375-9.

\section{Larroque 2003}

Larroque B, Marret S, Ancel PY, Arnaud C, Marpeau L, Supernant $\mathrm{K}$, et al. White matter damage and intraventricular hemorrhage in very preterm infants: the EPIPAGE study. Journal of Pediatrics 2003;143(4):477-83.

\section{Lassi 2015}

Lassi ZS, Middleton PF, Crowther C, Bhutta ZA. Interventions to improve neonatal health and later survival: an overview of systematic reviews. EBioMedicine 2015;2(8):983-98.

\section{MacLennan 2015}

MacLennan AH, Thompson SC, Gecz J. Cerebral palsy: causes, pathways, and the role of genetic variants. American Journal of Obstetrics and Gynecology 2015;213(6):779-88.

\section{McIntyre 2010}

McIntyre S, Novak I, Cusick A. Consensus research priorities for cerebral palsy: a Delphi survey of consumers, researchers, and clinicians. Developmental Medicine and Child Neurology 2010;52(3):270-5.

\section{McIntyre 2011}

McIntyre S, Morgan C, Walker K, Novak I. Cerebral palsy don't delay. Developmental Disabilities Research Reviews 2011;17(2):114-29.

\section{McIntyre 2013}

McIntyre S, Taitz D, Keogh J, Goldsmith S, Badawi N, Blair E. A systematic review of risk factors for cerebral palsy in children born at term in developed countries. Developmental Medicine and Child Neurology 2013;55:499-508.

\section{Moreno-De-Luca 2012}

Moreno-De-Luca A, Ledbetter DH, Martin CL. Genetic insights into the causes and classification of cerebral palsies. Lancet Neurology 2012;11(3):283-92.

\section{Morgan 2016}

Morgan C, Crowle C, Goyen T-A, Hardman C, Jackman M, Novak I, et al. Sensitivity and specificity of General Movements Assessment for diagnostic accuracy of detecting cerebral palsy early in an Australian context. Journal of Paediatrics and Child Health 2016;52(1):54-9.

\section{Morris 2004}

Morris C, Bartlett D. Gross Motor Function Classification System: impact and utility. Developmental Medicine \& Child Neurology 2004;46:60-5.

\section{Morris 2007}

Morris C. Definition and classification of cerebral palsy: a historical perspective. Developmental Medicine \& Child Neurology 2007;49:3-7.

\section{Mutch 1992}

Mutch L, Alberman E, Hagberg B, Kodama K, Perat MV. Cerebral palsy epidemiology: where are we now and where are we going?. Developmental Medicine \& Child Neurology 1992;34(6):547-51

\section{Nelson 2008}

Nelson KB, Chang T. Is cerebral palsy preventable?. Current Opinion in Neurology 2008;21(2):129-35.

\section{Nelson 2008b}

Nelson KB. Causative factors in cerebral palsy. Clinical Obstetrics and Gynecology 2008;51(4):749-62.

\section{Novak 2012}

Novak I, Hines M, Goldsmith S, Barclay R. Clinical prognostic messages from a systematic review of cerebral palsy. Paediatrics 2012;130(5):e1285-e1312.

\section{Oskoui 2013}

Oskoui M, Coutinho F, Dykeman J, Jetté N, Pringsheim T. An update on the prevalence of cerebral palsy: a systematic review and meta-analysis. Developmental Medicine \& Child Neurology 2013;55(6):509-19.

\section{Oskoui 2015}

Oskoui M, Gazzellone MJ, Thiruvahindrapuram B, Zarrei M, Andersen J, Wei J. Clinically relevant copy number variations detected in cerebral palsy. Nature Communications 2015;6:7949.

\section{O'Callaghan 2009}

O'Callaghan ME, MacLennan AH, Haan EA, Dekker G, South Australian Cerebral Palsy Research Group. The genomic basis of cerebral palsy: a HuGE systematic literature review. Human Genetics 2009;126(1):149-72.

\section{O'Shea 2008}

O'Shea MT. Diagnosis, treatment and prevention of cerebral palsy in near-term/term infants. Clinical Obstetrics and Gynaecology 2008;51(4):816-28.

\section{Palisano 1997}

Palisano R, Rosenbaum P, Walter S, Russell D, Wood E, Galuppi B. Development and reliability of a system to 
classify gross motor function in children with cerebral palsy. Developmental Medicine \& Child Neurology 1997;39(4):214-23.

\section{Reid 2012}

Reid SM, Carlin JB, Reddihough DS. Survival of individuals with cerebral palsy born in Victoria, Australia, between 1970 and 2004. Developmental Medicine \& Child Neurology 2012;54(4):353-60.

\section{Reid 2016}

Reid SM, Meehan E, Mclntyre S, Goldsmith S, Badawi N, Reddihough DS, the Australian Cerebral Palsy Register Group. Temporal trends in cerebral palsy by impairment severity and birth gestation. Developmental Medicine and Child Neurology 2016;58(Suppl 2):25-35.

\section{RevMan 2014 [Computer program]}

The Nordic Cochrane Centre, The Cochrane Collaboration. Review Manager 5 (RevMan 5). Version 5.3. Copenhagen: The Nordic Cochrane Centre, The Cochrane Collaboration, 2014.

\section{Roberts 2017}

Roberts D, Brown J, Medley N, Dalziel SR. Antenatal corticosteroids for accelerating fetal lung maturation for women at risk of preterm birth. Cochrane Database of Systematic Reviews 2017, Issue 3. [DOI: 10.1002/14651858.CD004454.pub3]

\section{Robertson 2012}

Robertson NJ, Tan S, Groenendaal F, Van Bel F, Juul SE, Bennet $L$, et al. Which neuroprotective agents are ready for bench to bedside translation in the newborn infant?. Journal of Pediatrics 2012;160:544-52.

\section{Rosenbaum 2007}

Rosenbaum P, Paneth N, Leviton A, Goldstein M, Bax M, Damiano $D$, et al. A report: the definition and classification of cerebral palsy April 2006. Developmental Medicine and Child Neurology Supplement 2007;109:8-14.

\section{Saliba 2001}

Saliba E, Marret S. Cerebral white matter damage in the preterm infant: pathophysiology and risk factors. Seminars in Neonatology 2001;6(2):121-33.

\section{Sanger 2003}

Sanger TD, Delgado MR, Gaebler-Spira D, Hallett M, Mink JW, Task Force on Childhood Motor Disorders. Classification and definition of disorders causing hypertonia in childhood. Pediatrics 2003;111(1):e89-97.

\section{Sankar 2005}

Sankar C, Mundkur N. Cerebral palsy-definition, classification, etiology and early diagnosis. Indian Journal of Pediatrics 2005;72(10):865-8

\section{Schünemann 2013}

Schünemann H, Brożek J, Guyatt G, Oxman A (editors). GRADE Handbook. The GRADE Working Group, 2013. Available from gdt.guidelinedevelopment.org/app/handbook/handbook.html.

\section{Sellier 2015}

Sellier E, Platt MJ, Andersen GL, Krägeloh-Mann I, De La Cruz J, Cans $C$, et al. Decreasing prevalence in cerebral palsy: a multi-site European population-based study, 1980 to 2003. Developmental Medicine and Child Neurology 2015;58:85-92.

\section{Shea 2009}

Shea BJ, Hamel C, Wells GA, Bouter LM, Kristjansoon E, Grimshaw J, et al. AMSTAR is a reliable and valid measurement tool to assess the methodological quality of systematic reviews. Journal of Clinical Epidemiology 2009;62(10):1013-20.

\section{Shepherd 2016}

Shepherd E, Middleton P, Makrides M, McIntyre SJ, Badawi N, Crowther CA. Neonatal interventions for preventing cerebral palsy: an overview of Cochrane systematic reviews. Cochrane Database of Systematic Reviews 2016, Issue 10. [DOI: 10.1002/14651858.CD012409]

\section{Smithers-Sheedy 2014}

Smithers-Sheedy H, Badawi N, Blair E, Cans C, Himmelmann K, Krägeloh-Mann I, et al. What constitutes cerebral palsy in the twenty-first century?. Developmental Medicine and Child Neurology 2014;56:323-8.

\section{Strauss 2008}

Strauss D, Brooks J, Rosenbloom L, Shavelle R. Life expectancy in cerebral palsy: an update. Developmental Medicine \& Child Neurology 2008;50(7):487-93.

\section{Vexler 2001}

Vexler ZS, Ferriero DM. Molecular and biochemical mechanisms of perinatal brain injury. Seminars in Neonatology 2011;6:99-108.

\section{Volpe 2000}

Volpe JJ. Perinatal brain injury: from pathogenesis to neuroprotection. Mental Retardation and Developmental Disabilities Research Reviews 2000;7:56-64.

\section{Whiting 2014}

Whiting P, Savovic J, Higgins J, Shea B, Reeves B, Caldwell D, et al. ROBIS: a new tool to assess the risk of bias in a systematic review. Cochrane Colloquium. 2014 September 21-16; Hyderabad. Hyderabad, India: Cochrane Collaboration. Available from colloquium.cochrane.org/abstracts/robis-newtool-assess-risk-bias-systematic-review, 2014.

\section{WHO 2015}

World Health Organization (WHO). WHO recommendations on interventions to improve preterm birth outcomes. Available from who.int/reproductivehealth/publications/maternal_ perinatal_health/preterm-birth-guideline/en 2015; Vol. (accessed 20 August 2016).

\section{Wood 2000}

Wood E, Rosenbaum P. The gross motor function classification system for cerebral palsy: a study of reliability and stability over time. Developmental Medicine \& Child Neurology 2000;42:292-6.

\section{ADDITIONAL TABLES}

Antenatal and intrapartum interventions for preventing cerebral palsy: an overview of Cochrane systematic reviews (Review) 
Table 1. Characteristics of excluded reviews

\begin{tabular}{ll}
\hline Review ID & Reason for exclusion \\
\hline Abou El Senoun 2014 & Secondary neonatal outcomes included: \\
- Disability at time of childhood follow-up (as defined by authors). \\
- Serious disability (as defined by authors) after two years.
\end{tabular}

No outcome data for these outcomes.

\begin{tabular}{ll} 
Bricker 2015 & Primary outcomes included: \\
- Neurodevelopment at age two. & No outcome data for this outcome. \\
\hline Buchanan 2010 & Secondary neonatal outcomes included: \\
- Disability at time of childhood follow-up. & No outcome data for this outcome.
\end{tabular}

\begin{tabular}{ll}
\hline Chapman 2014 & No outcomes focused on development or disability at follow-up. \\
\hline Crowley 2016 & Secondary infant outcomes included: \\
- Neurodevelopmental delay at 12 months and 24 months. \\
No outcome data for this outcome.
\end{tabular}

Dare 2006 foetal, neonatal, and infant outcomes included:

- Disability at time of childhood follow-up.

No outcome data for this outcome

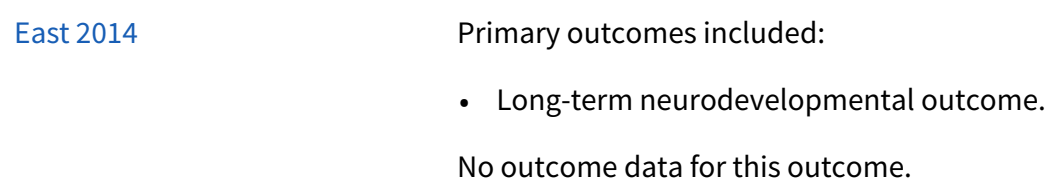

Gomi $2015 \quad$ No outcomes focused on development or disability at follow-up.

Han 2013 Primary outcomes included:

- Any neurological disability at follow-up.

No outcome data for this outcome.

- Perinatal or infant death (excluding fatal anomalies) or disability in childhood.

Secondary long-term infant outcomes included:

- Disability in childhood, as defined by trial authors.

No outcome data for these outcomes. 


\section{Table 1. Characteristics of excluded reviews (Continued)}
Kenyon 2013
Secondary outcome included:
- Long-term health outcomes (as defined by trial authors) after at least two years.
Outcome data only reported for 'Serious childhood disability at seven years'.

\begin{tabular}{|c|c|}
\hline Khunpradit 2011 & $\begin{array}{l}\text { Secondary outcomes include: } \\
\text { - Neonatal neurodevelopment. } \\
\text { No outcome data for this outcome. }\end{array}$ \\
\hline Kiiza 2015 & $\begin{array}{l}\text { Protocol. } \\
\text { Secondary baby outcomes will include: } \\
\text { - Long-term neurodevelopmental outcome. }\end{array}$ \\
\hline Lewin 2010 & No outcomes focused on development or disability at follow-up. \\
\hline Lutomski 2015 & No outcomes focused on development or disability at follow-up. \\
\hline Mackeen 2014 & No outcomes focused on development or disability at follow-up. \\
\hline Neilson 2003 & No outcomes focused on development or disability at follow-up. \\
\hline Olsen 2012 & No outcomes focused on development or disability at follow-up. \\
\hline Othman 2007 & No outcomes focused on development or disability at follow-up. \\
\hline Sangkomkamhang 2015 & No outcomes focused on development or disability at follow-up. \\
\hline Say 1996 & No outcomes focused on development or disability at follow-up. \\
\hline Say 1996a & No outcomes focused on development or disability at follow-up. \\
\hline Say 1996b & No outcomes focused on development or disability at follow-up. \\
\hline Say $1996 c$ & No outcomes focused on development or disability at follow-up. \\
\hline Say 2001 & No outcomes focused on development or disability at follow-up. \\
\hline Say 2003 & No outcomes focused on development or disability at follow-up. \\
\hline Say $2003 a$ & No outcomes focused on development or disability at follow-up. \\
\hline Say 2003b & No outcomes focused on development or disability at follow-up. \\
\hline Siegfried 2011 & No outcomes focused on development or disability at follow-up. \\
\hline Siriwachirachai 2014 & No outcomes focused on development or disability at follow-up. \\
\hline Stan 2013 & $\begin{array}{l}\text { Secondary outcomes included: } \\
\text { - Long-term sequelae: neurologic impairment and chronic lung disease. } \\
\text { No outcome data for this outcome. }\end{array}$ \\
\hline Thomas 2007 & Outcomes included: \\
\hline
\end{tabular}


Table 1. Characteristics of excluded reviews (Continued)

- Adverse neonatal outcomes in terms of longer-term neurological outcomes.

No outcome data for this outcome.

Table 2. Characteristics of included reviews

\begin{tabular}{|c|c|c|c|c|c|c|}
\hline Review ID & $\begin{array}{l}\text { Date of } \\
\text { search; } \\
\text { date as- } \\
\text { sessed as } \\
\text { up-to-date }\end{array}$ & $\begin{array}{l}\text { No. included tri- } \\
\text { als; countries and } \\
\text { years of publica- } \\
\text { tion }\end{array}$ & $\begin{array}{l}\text { No. partici- } \\
\text { pants in in- } \\
\text { cluded tri- } \\
\text { als }\end{array}$ & $\begin{array}{l}\text { Inclusion } \\
\text { criteria for } \\
\text { "Types of } \\
\text { participants" }\end{array}$ & $\begin{array}{l}\text { Relevant } \\
\text { compari- } \\
\text { son inter- } \\
\text { ventions } \\
\text { (no. trials } \\
\text { and partic- } \\
\text { ipants) }\end{array}$ & $\begin{array}{l}\text { Overview outcomes for which } \\
\text { data were reported (pre-speci- } \\
\text { fied unless stated otherwise) }\end{array}$ \\
\hline $\begin{array}{l}\text { Abalos } \\
2014\end{array}$ & $\begin{array}{l}30 \text { April } \\
2013\end{array}$ & $\begin{array}{l}49 \text { RCTs } \\
34 \text { RCTs in indus- } \\
\text { trialised countries } \\
\text { (Australia, France, } \\
\text { Hong Kong, Ire- } \\
\text { land, Israel, Italy, } \\
\text { Sweden, UK and } \\
\text { USA) } \\
\text { 15 RCTs in low- or } \\
\text { middle-income } \\
\text { countries (Ar- } \\
\text { gentina, Brazil, } \\
\text { Caribbean Is- } \\
\text { lands, India, South } \\
\text { Africa, Sudan and } \\
\text { Venezuela) } \\
\text { RCTs published in: } \\
\text { 1960s: } 1 \\
\text { 1970s: } 2 \\
\text { 1980s: } 22 \\
\text { 1990s: } 17 \\
\text { 2000s: } 5 \\
\text { 2010s; } 2\end{array}$ & $\begin{array}{l}4723 \\
\text { women and } \\
\text { their babies }\end{array}$ & $\begin{array}{l}\text { women with } \\
\text { mild to mod- } \\
\text { erate hyper- } \\
\text { tension dur- } \\
\text { ing pregnan- } \\
\text { cy, regardless } \\
\text { of whether or } \\
\text { not they had } \\
\text { proteinuria, } \\
\text { previous anti- } \\
\text { hypertensive } \\
\text { treatment, or } \\
\text { whether the } \\
\text { pregnancy } \\
\text { was singleton } \\
\text { or multiple }\end{array}$ & $\begin{array}{l}\text { any antihy- } \\
\text { pertensive } \\
\text { drug versus } \\
\text { no drugs } \\
\text { (29 RCTs, } \\
3350 \\
\text { women) }\end{array}$ & $\begin{array}{l}\text { cerebral palsy reported as a sec- } \\
\text { ondary outcome } \\
\text { primary outcome was impaired } \\
\text { long-term growth and develop- } \\
\text { ment in infancy and childhood }\end{array}$ \\
\hline $\begin{array}{l}\text { Alfirevic } \\
2013\end{array}$ & $\begin{array}{l}\text { Search: } 31 \\
\text { December } \\
2012 \\
\text { Up-to-date: } \\
31 \text { January } \\
2013\end{array}$ & $\begin{array}{l}13 \text { RCTs (1 qRCT) } \\
\text { No. RCTs in: } \\
\text { Australia: } 2 \\
\text { Denmark: } 1 \\
\text { Greece: } 1 \\
\text { India: } 1 \\
\text { Ireland: } 2\end{array}$ & $\begin{array}{l}37,715 \\
\text { women and } \\
\text { their babies }\end{array}$ & $\begin{array}{l}\text { pregnant } \\
\text { women in } \\
\text { labour and } \\
\text { their babies }\end{array}$ & $\begin{array}{l}\text { continu- } \\
\text { ous car- } \\
\text { diotocogra- } \\
\text { phy versus } \\
\text { intermit- } \\
\text { tent auscul- } \\
\text { tation } \\
\text { (12 RCTs, } \\
33,681 \\
\text { women) }\end{array}$ & $\begin{array}{l}\text { cerebral palsy reported as a pri- } \\
\text { mary review outcome }\end{array}$ \\
\hline
\end{tabular}


Table 2. Characteristics of included reviews (Continued)

Pakistan: 1

Sweden: 1

UK: 1

USA: 3

RCTs published in:

1970s: 4

1980s: 6

1990s: 2

2000s: 1

\begin{tabular}{|c|c|c|c|c|c|c|}
\hline $\begin{array}{l}\text { Churchill } \\
2013\end{array}$ & $\begin{array}{l}\text { Search: } 28 \\
\text { February } \\
2013 \\
\text { Up-to-date: } \\
10 \text { July } \\
2013\end{array}$ & $\begin{array}{l}4 \text { RCTs } \\
\text { No. RCTs in: } \\
\text { Egypt: } 1 \\
\text { Europe: } 1 \\
\text { South Africa: } 1 \\
\text { USA: } 1 \\
\text { RCTs published in: } \\
\text { 1990s: } 2 \\
\text { 2000s: } 2\end{array}$ & $\begin{array}{l}425 \text { women } \\
\text { and their } \\
\text { babies }\end{array}$ & $\begin{array}{l}\text { women with } \\
\text { severe pre- } \\
\text { eclampsia, up } \\
\text { to and includ- } \\
\text { ing } 34 \text { weeks' } \\
\text { gestation }\end{array}$ & $\begin{array}{l}\text { interven- } \\
\text { tionist care } \\
\text { versus ex- } \\
\text { pectant } \\
\text { (delayed } \\
\text { delivery) } \\
\text { care } \\
\text { (4 RCTs, } 425 \\
\text { women) }\end{array}$ & $\begin{array}{l}\text { cerebral palsy reported as a sec- } \\
\text { ondary review outcome } \\
\text { pre-specified outcome was 'mea- } \\
\text { sures of long-term growth and } \\
\text { development, such as important } \\
\text { impairment and cerebral palsy' }\end{array}$ \\
\hline $\begin{array}{l}\text { Crowther } \\
2010\end{array}$ & $\begin{array}{l}\text { Search: } 20 \\
\text { December } \\
2010 \\
\text { Up-to-date: } \\
15 \text { February } \\
2011\end{array}$ & $\begin{array}{l}8 \text { RCTs Countries } \\
\text { of trials not re- } \\
\text { ported } \\
\text { RCTs published in: } \\
\text { 1980s: } 4 \\
\text { 1990s: } 3 \\
\text { 2000s: } 1\end{array}$ & $\begin{array}{l}879 \text { women } \\
\text { and their } \\
\text { babies }\end{array}$ & $\begin{array}{l}\text { women at risk } \\
\text { of imminent } \\
\text { very preterm } \\
\text { birth }\end{array}$ & $\begin{array}{l}\text { vitamin } \mathrm{K} \\
\text { versus con- } \\
\text { trol } \\
\text { (8 RCTs, } 879 \\
\text { women) }\end{array}$ & $\begin{array}{l}\text { cerebral palsy reported as a pri- } \\
\text { mary review outcome } \\
\text { pre-specified outcome was long- } \\
\text { term neurodevelopment }\end{array}$ \\
\hline $\begin{array}{l}\text { Crowther } \\
2010 a\end{array}$ & $\begin{array}{l}\text { Search: } 20 \\
\text { December } \\
2010 \\
\text { Up-to-date: } \\
9 \text { January } \\
2011\end{array}$ & $\begin{array}{l}9 \text { RCTs } \\
\text { Countries of trials } \\
\text { not reported } \\
\text { RCTs published in: } \\
\text { 1980s: } 4 \\
\text { 1990s: } 5\end{array}$ & $\begin{array}{l}1752 \\
\text { women and } \\
\text { their babies }\end{array}$ & $\begin{array}{l}\text { women at risk } \\
\text { of imminent } \\
\text { very preterm } \\
\text { birth (before } \\
34 \text { weeks' ges- } \\
\text { tation) }\end{array}$ & $\begin{array}{l}\text { phenobar- } \\
\text { bital versus } \\
\text { control } \\
\text { (9 RCTs, } \\
1752 \\
\text { women) }\end{array}$ & $\begin{array}{l}\text { cerebral palsy, motor dysfunc- } \\
\text { tion (other neuromotor impair- } \\
\text { ment) reported as primary review } \\
\text { outcomes } \\
\text { pre-specified outcome was 'long- } \\
\text { term neurodevelopment' }\end{array}$ \\
\hline $\begin{array}{l}\text { Crowther } \\
2014\end{array}$ & $\begin{array}{l}31 \text { January } \\
2014\end{array}$ & $\begin{array}{l}37 \text { RCTs (4 qRCTs) } \\
\text { No. RCTs in: China: } \\
3 \\
\text { Iran: } 5\end{array}$ & $\begin{array}{l}3571 \\
\text { women and } \\
\text { their babies }\end{array}$ & $\begin{array}{l}\text { women con- } \\
\text { sidered to be } \\
\text { in preterm } \\
\text { labour given } \\
\text { magnesium } \\
\text { sulphate to re- }\end{array}$ & $\begin{array}{l}\text { magnesium } \\
\text { sulphate } \\
\text { versus } \\
\text { placebo, no } \\
\text { treatment, } \\
\text { or other }\end{array}$ & $\begin{array}{l}\text { cerebral palsy reported as a sec- } \\
\text { ondary review outcome } \\
\text { primary review outcome was } \\
\text { a composite outcome includ- } \\
\text { ing cerebral palsy, listed as 'se- }\end{array}$ \\
\hline
\end{tabular}


Table 2. Characteristics of included reviews (Continued)

Italy: 1

Mexico: 1

Thailand: 1

Turkey: 1

USA: 25

RCTs published in:

1980s: 7

1990s: 18

2000s: 10

2010s: 2 duce their risk tocolytic of preterm agent

birth

(37 RCTs,

3571

women) rious infant outcome' ("...death or chronic lung disease...grade three or four intraventricular haemorrhage or periventricular leukomalacia, major neurosensory disability (legal blindness, sensorineural deafness requiring hearing aids, moderate or severe cerebral palsy, or developmental delay or intellectual impairment...))"

\begin{tabular}{|c|c|c|c|c|c|}
\hline $\begin{array}{l}\text { Crowther } \\
2015\end{array}$ & $\begin{array}{l}20 \text { January } \\
2015\end{array}$ & $\begin{array}{l}10 \text { RCTs } \\
\text { No. RCTs in: } \\
\text { Australia and New } \\
\text { Zealand: } 1 \\
\text { Canada: } 1 \\
\text { Finland: } 1 \\
\text { India: } 1 \\
\text { USA: } 5\end{array}$ & $\begin{array}{l}4733 \\
\text { women and } \\
\text { their babies }\end{array}$ & $\begin{array}{l}\text { women con- } \\
\text { sidered to } \\
\text { be at risk } \\
\text { of preterm } \\
\text { birth who had } \\
\text { already re- } \\
\text { ceived a single } \\
\text { course of pre- } \\
\text { natal corticos- } \\
\text { teroid seven } \\
\text { or more days } \\
\text { previously }\end{array}$ & $\begin{array}{l}\text { repeat dos- } \\
\text { es of prena- } \\
\text { tal corticos- } \\
\text { teroids ver- } \\
\text { sus placebo } \\
\text { or no treat- } \\
\text { ment } \\
\text { (10 RCTs, } \\
4733 \\
\text { women) }\end{array}$ \\
\hline
\end{tabular}

20 countries: 1

RCTs published in:

2000s: 9

2010s: 1

\begin{tabular}{|c|c|c|c|c|c|c|}
\hline Dodd 2013 & $\begin{array}{l}14 \text { January } \\
2013\end{array}$ & $\begin{array}{l}36 \text { RCTs } \\
\text { No. RCTs in: } \\
\text { Albania: } 1 \\
\text { Brazil: } 1 \\
\text { Denmark and Aus- } \\
\text { tria: } 1 \\
\text { Egypt: } 3 \\
\text { Finland: } 1 \\
\text { France: } 3 \\
\text { India: } 2 \\
\text { Iran: } 5 \\
\text { Italy: } 1\end{array}$ & $\begin{array}{l}8523 \\
\text { women and } \\
\text { their babies }\end{array}$ & $\begin{array}{l}\text { pregnant } \\
\text { women con- } \\
\text { sidered to } \\
\text { be at in- } \\
\text { creased risk of } \\
\text { preterm birth: } \\
\text { - Past history } \\
\text { of sponta- } \\
\text { neous } \\
\text { preterm } \\
\text { birth } \\
\text { - Multiple } \\
\text { pregnancy } \\
\text { - Ultrasound } \\
\text { identified } \\
\text { short cervi- } \\
\text { cal length } \\
\text { - fetal fi- } \\
\text { bronectin } \\
\text { testing }\end{array}$ & $\begin{array}{l}\text { proges- } \\
\text { terone ver- } \\
\text { sus placebo } \\
\text { or no treat- } \\
\text { ment } \\
(11 \text { RCTs, } \\
1899)\end{array}$ & $\begin{array}{l}\text { cerebral palsy reported as a sec- } \\
\text { ondary review outcome } \\
\text { motor dysfunction, pre-specified } \\
\text { as motor impairment, reported } \\
\text { as secondary review outcome }\end{array}$ \\
\hline
\end{tabular}

Antenatal and intrapartum interventions for preventing cerebral palsy: an overview of Cochrane systematic reviews (Review) 
Table 2. Characteristics of included reviews (Continued)

Spain: 1

Turkey: 1

UK: 1

USA: 11

international: 3

RCTs published in:

1970s: 2

1980s: 2

2000s: 13

2010s: 19
- Following acute presentation with symptoms or signs of threatened preterm labour

- Other reason considered to be at increased risk of preterm birth

\begin{tabular}{|c|c|c|c|c|c|}
\hline Doyle 2009 & $\begin{array}{l}\text { Search: } \\
31 \text { August } \\
2008 \\
\text { Up-to-date: } \\
5 \text { Novem- } \\
\text { ber } 2008\end{array}$ & $\begin{array}{l}5 \text { RCTs } \\
\text { No. RCTs in: Aus- } \\
\text { tralia and New } \\
\text { Zealand: } 1 \\
\text { France: } 1 \\
\text { USA: } 2\end{array}$ & $\begin{array}{l}5560 \\
\text { women and } \\
\text { their } 6145 \\
\text { babies }\end{array}$ & $\begin{array}{l}\text { women con- } \\
\text { sidered to } \\
\text { be at risk of } \\
\text { preterm birth }\end{array}$ & $\begin{array}{l}\text { magne- } \\
\text { sium sul- } \\
\text { phate ver- } \\
\text { sus placebo } \\
\text { ( } 5 \text { RCTs, } \\
6145 \text { ba- } \\
\text { bies) }\end{array}$ \\
\hline
\end{tabular}

international; 1 (predominately in developing countries)

RCTs published in: 2000s: 5

6145 ba- cerebral palsy; cerebral palsy or death; severity of cerebral palsy (mild, moderate, moderate to severe, severe cerebral palsy); composite outcomes including cerebral palsy (any neurologic impairment; major neurological disability; death or any neurologic impairment; death or major neurological disability); motor dysfunction (substantial gross motor dysfunction; death or substantial gross motor dysfunction) reported as primary outcomes

pre-specified outcomes were: neurological impairments (developmental delay or intellectual impairment (developmental quotient or intelligence quotient less than one standard deviation (SD) below the mean), cerebral palsy (abnormality of tone with motor dysfunction), blindness (corrected visual acuity worse than $6 / 60$ in the better eye), or deafness (hearing loss requiring amplification or worse)); neurological disabilities (abnormal neurological function caused by any of the preceding impairments) at follow-up later in childhood; substantial gross motor dysfunction (motor dysfunction such that the child was not walking at age two years or later, or the inability to grasp and release a small block with both hands); major neurological disability (legal blindness, sensorineural deafness requiring hearing aids, moderate or severe cerebral palsy, developmental delay or intellectual impair- 
Table 2. Characteristics of included reviews (Continued)

ment (developmental quotient or intelligence quotient less than two SD below the mean)); paediatric mortality combined with cerebral palsy, substantial gross motor dysfunction, neurological impairment, or major neurological disability (these combined outcomes recognise the competing risks of death or survival with neurological problems)

\begin{tabular}{|c|c|c|c|c|c|c|}
\hline Duley 2010 & $\begin{array}{l}\text { Search: } 4 \\
\text { June } 2010 \\
\text { Up-to-date: } \\
1 \text { Septem- } \\
\text { ber } 2010\end{array}$ & $\begin{array}{l}15 \text { RCTs } \\
\text { No. RCTs in: Den- } \\
\text { mark: } 1 \\
\text { India; } 1 \\
\text { Malaysia: } 1 \\
\text { Mexico: } 2 \\
\text { South Africa: } 2 \\
\text { Taiwan: } 1 \\
\text { USA: } 5 \\
\text { international: } 2 \\
\text { (1 in } 33 \text { countries, } \\
\text { with } 85 \% \text { recruit- } \\
\text { ment in low- and } \\
\text { middle-income } \\
\text { countries; } 1 \text { in } 8 \\
\text { countries) } \\
\text { RCTs published in: } \\
\text { 1990s: } 10 \\
\text { 2000s: } 5\end{array}$ & $\begin{array}{l}15,570 \\
\text { women and } \\
\text { their babies }\end{array}$ & $\begin{array}{l}\text { any women } \\
\text { with pre- } \\
\text { eclampsia, re- } \\
\text { gardless of } \\
\text { whether: be- } \\
\text { fore or after } \\
\text { delivery, a sin- } \\
\text { gleton or mul- } \\
\text { tiple pregnan- } \\
\text { cy, or whether } \\
\text { an anticonvul- } \\
\text { sant had been } \\
\text { given before } \\
\text { trial entry }\end{array}$ & $\begin{array}{l}\text { magne- } \\
\text { sium sul- } \\
\text { phate ver- } \\
\text { sus placebo } \\
\text { or no anti- } \\
\text { convulsant } \\
\text { (6 RCTs, } \\
11,444 \\
\text { women) }\end{array}$ & $\begin{array}{l}\text { severe cerebral palsy; other com- } \\
\text { posite outcomes including cere- } \\
\text { bral palsy (neurosensory disabil- } \\
\text { ity; death or neurosensory dis- } \\
\text { ability) were all reported as sec- } \\
\text { ondary review outcomes } \\
\text { pre-specified outcomes were } \\
\text { 'long-term growth and devel- } \\
\text { opment: blindness, deafness, } \\
\text { seizures, poor growth, neurode- } \\
\text { velopmental delay and cerebral } \\
\text { palsy' }\end{array}$ \\
\hline $\begin{array}{l}\text { Flenady } \\
2013\end{array}$ & $\begin{array}{l}\text { Search: } \\
31 \text { August } \\
2013 \\
\text { Up-to-date: } \\
3 \text { October } \\
2013\end{array}$ & $\begin{array}{l}\text { 14 RCTs } \\
\text { No. RCTs in: } \\
\text { Canada: } 1 \\
\text { Chile: } 1 \\
\text { Denmark: } 1 \\
\text { Germany: } 1 \\
\text { Iran: } 1 \\
\text { South Africa: } 1 \\
\text { Uruguay: } 1 \\
\text { USA: } 6 \\
\text { international: } 1\end{array}$ & $\begin{array}{l}7837 \\
\text { women and } \\
\text { their babies }\end{array}$ & $\begin{array}{l}\text { women } \\
\text { thought to } \\
\text { be in preterm } \\
\text { labour with } \\
\text { intact mem- } \\
\text { branes, be- } \\
\text { tween } 20 \text { and } \\
36 \text { completed } \\
\text { weeks of ges- } \\
\text { tation }\end{array}$ & $\begin{array}{l}\text { any antibi- } \\
\text { otics versus } \\
\text { no antibi- } \\
\text { otics } \\
\text { (14 RCTs, } \\
7837 \\
\text { women) }\end{array}$ & $\begin{array}{l}\text { cerebral palsy reported as a pri- } \\
\text { mary review outcome } \\
\text { pre-specified outcome was 'ma- } \\
\text { jor long-term infant neurosenso- } \\
\text { ry impairment' }\end{array}$ \\
\hline
\end{tabular}

Antenatal and intrapartum interventions for preventing cerebral palsy: an overview of Cochrane systematic reviews (Review) 
Table 2. Characteristics of included reviews (Continued)

RCTs published in:

1980s: 1

1990s: 10

2000s: 3

\begin{tabular}{|c|c|c|c|c|c|c|}
\hline Magee 2003 & $\begin{array}{l}\text { Search: } \\
4 \text { July } 2012 \\
\text { (results } \\
\text { added to } \\
\text { Studies } \\
\text { awaiting } \\
\text { classifica- } \\
\text { tion) } \\
\text { Up-to-date: } \\
30 \text { January } \\
2004\end{array}$ & $\begin{array}{l}29 \text { RCTs } \\
\text { No. RCTs in: } \\
\text { Argentina: } 1 \\
\text { Australia: } 2 \\
\text { Brazil: } 1 \\
\text { England: } 5 \\
\text { Fr Caribbean: } 1 \\
\text { France: } 3 \\
\text { Hong Kong: } 1 \\
\text { India: } 1 \\
\text { Israel: } 4 \\
\text { Scotland: } 4 \\
\text { Sweden: } 3 \\
\text { USA: } 2 \\
\text { Venezuela: } 1 \\
\text { RCTs published in: } \\
\text { 1970s: } 1 \\
\text { 1980s: } 17 \\
\text { 1990s: } 11\end{array}$ & $\begin{array}{l}2548 \\
\text { women and } \\
\text { their babies }\end{array}$ & $\begin{array}{l}\text { women with } \\
\text { mild to mod- } \\
\text { erate hyper- } \\
\text { tension dur- } \\
\text { ing pregnan- } \\
\text { cy, however } \\
\text { defined }\end{array}$ & $\begin{array}{l}\text { beta-block- } \\
\text { ers versus } \\
\text { placebo } \\
\text { or no be- } \\
\text { ta-blocker } \\
\text { (13 RCTs, } \\
1480 \\
\text { women) }\end{array}$ & $\begin{array}{l}\text { Cerebral palsy reported as a re- } \\
\text { view outcome, rather than prima- } \\
\text { ry or secondary } \\
\text { pre-specified outcome was 'mea- } \\
\text { sures of long-term health and de- } \\
\text { velopment such as cerebral pal- } \\
\text { sy' }\end{array}$ \\
\hline $\begin{array}{l}\text { Neilson } \\
2014\end{array}$ & $\begin{array}{l}31 \text { Decem- } \\
\text { ber } 2013\end{array}$ & $\begin{array}{l}28 \text { RCTs (20 RCTs } \\
\text { contributed data) } \\
\text { No. RCTs in: } \\
\text { Australia: } 1 \\
\text { Canada: } 1 \\
\text { Europe: } 6 \\
\text { Iran: } 1 \\
\text { Italy: } 1 \\
\text { Japan: } 1 \\
\text { Sweden: } 1 \\
\text { USA: } 10\end{array}$ & $\begin{array}{l}2715 \\
\text { women and } \\
\text { their babies } \\
\text { in } 20 \text { RCTs }\end{array}$ & $\begin{array}{l}\text { pregnant } \\
\text { women as- } \\
\text { sessed as be- } \\
\text { ing in spon- } \\
\text { taneous } \\
\text { preterm } \\
\text { labour and } \\
\text { considered } \\
\text { suitable for } \\
\text { tocolytic } \\
\text { agents }\end{array}$ & $\begin{array}{l}\text { betamimet- } \\
\text { ics versus } \\
\text { placebo } \\
\text { (12 RCTs, } \\
1367 \\
\text { women) }\end{array}$ & $\begin{array}{l}\text { Cerebral palsy reported as a pri- } \\
\text { mary review outcome } \\
\text { pre-specified outcome was 'ab- } \\
\text { normal long-term neurodevel- } \\
\text { opmental status at more than } 12 \\
\text { months corrected age (moder- } \\
\text { ate to severe developmental de- } \\
\text { lay, cerebral palsy, sensory im- } \\
\text { pairment, for example, blind and } \\
\text { deaf, or a combination)' }\end{array}$ \\
\hline
\end{tabular}


Table 2. Characteristics of included reviews (Continued)

not reported: 6

RCTs published in:

1960s: 1

1970s: 5

1980s: 18

1990s: 3

2010s: 1

\begin{tabular}{|c|c|c|c|c|c|c|}
\hline $\begin{array}{l}\text { Roberts } \\
2006\end{array}$ & $\begin{array}{l}\text { Search: } 30 \\
\text { April } 2010 \\
\text { (added the } \\
\text { search to } \\
\text { Studies } \\
\text { awaiting } \\
\text { classifica- } \\
\text { tion) } \\
\text { Up-to-date: } \\
15 \text { May } \\
2006\end{array}$ & $\begin{array}{l}21 \text { RCTs } \\
\text { No. RCTs in: } \\
\text { Brazil: } 1 \\
\text { Canada: } 1 \\
\text { Finland: } 2 \\
\text { Jordan: } 1 \text { RCT } \\
\text { Netherlands: } 1 \\
\text { New Zealand: } 1 \\
\text { South Africa: } 1 \\
\text { Spain: } 1\end{array}$ & $\begin{array}{l}\text { over } 3999 \\
\text { women } \\
\text { (data } \\
\text { available } \\
\text { for } 3885 \\
\text { women and } \\
\text { their ba- } \\
\text { bies) }\end{array}$ & $\begin{array}{l}\text { women with } \\
\text { a singleton or } \\
\text { multiple preg- } \\
\text { nancy, expect- } \\
\text { ed to deliver } \\
\text { preterm as a } \\
\text { result of either } \\
\text { spontaneous } \\
\text { preterm } \\
\text { labour, } \\
\text { preterm pre- } \\
\text { labour rup- } \\
\text { ture of the } \\
\text { membranes, } \\
\text { or elective } \\
\text { preterm deliv- } \\
\text { ery }\end{array}$ & $\begin{array}{l}\text { antenatal } \\
\text { corticos- } \\
\text { teroids ver- } \\
\text { sus placebo } \\
\text { or no treat- } \\
\text { ment } \\
\text { ( } 21 \text { RCTs, } \\
3885 \\
\text { women) }\end{array}$ & $\begin{array}{l}\text { cerebral palsy reported as a sec- } \\
\text { ondary review outcome } \\
\text { other composite outcome includ- } \\
\text { ing cerebral palsy (neurodevelop- } \\
\text { mental delay) reported as a pri- } \\
\text { mary review outcome } \\
\text { pre-specified primary outcome } \\
\text { was 'neurodevelopmental dis- } \\
\text { ability' at follow-up (blindness, } \\
\text { deafness, moderate/severe cere- } \\
\text { bral palsy (however defined by } \\
\text { authors), or development delay } \\
\text { or intellectual impairment (de- } \\
\text { fined as developmental quotient } \\
\text { or intelligence quotient less than } \\
2 \text { SD below population mean))' }\end{array}$ \\
\hline
\end{tabular}

Tunisia: 1

UK: 1

USA: 10

RCTs published in:

1970s: 3

1980s: 8

1990s: 8

2000s: 2

\begin{tabular}{|c|c|c|c|c|c|c|}
\hline Stock 2016 & $\begin{array}{l}30 \text { April } \\
2016\end{array}$ & $\begin{array}{l}1 \text { RCT } \\
1 \text { RCT in Belgium, } \\
\text { Cyprus, Czech Re- } \\
\text { public, Germany, } \\
\text { Greece, Hungary, } \\
\text { Italy, Netherlands, } \\
\text { Poland, Portu- } \\
\text { gal, Saudi Arabia, } \\
\text { Slovenia, United } \\
\text { Kingdom }\end{array}$ & $\begin{array}{l}548 \text { women } \\
\text { and their } \\
\text { babies }\end{array}$ & $\begin{array}{l}\text { pregnant } \\
\text { women at } \\
\text { less than } 36 \\
\text { weeks' gesta- } \\
\text { tion in whom } \\
\text { there was clin- } \\
\text { ical suspicion } \\
\text { of fetal com- } \\
\text { promise as } \\
\text { defined by tri- } \\
\text { alists }\end{array}$ & $\begin{array}{l}\text { Immedi- } \\
\text { ate delivery } \\
\text { versus de- } \\
\text { ferred de- } \\
\text { livery } \\
\text { (1 RCT, } 548 \\
\text { women) }\end{array}$ & $\begin{array}{l}\text { cerebral palsy reported as a sec- } \\
\text { ondary outcome } \\
\text { other composite outcomes in- } \\
\text { cluding cerebral palsy (death or } \\
\text { disability at or after two years of } \\
\text { age) reported as a primary review } \\
\text { outcome } \\
\text { 'neurodevelopmental impair- } \\
\text { ment at or after two years of age' } \\
\text { reported as a secondary outcome }\end{array}$ \\
\hline
\end{tabular}

RCT published in

2000s 
Table 2. Characteristics of included reviews (Continued)

'death or severe disability in childhood' reported but not prespecified

Abbreviation: RCT: randomised controlled trial

Table 3. Risk of bias assessments from included reviews

\begin{tabular}{ll}
\hline Review ID & Summary of trial limitations (risk of bias) \\
\hline Abalos 2014 & Sequence generation: 12 RCTs low risk; 35 RCTs unclear risk; 2 RCTs high risk \\
& Allocation concealment: 17 RCTs low risk; 32 RCTs unclear risk \\
& Blinding (participants and personnel): 10 RCTs low risk; 1 RCT unclear risk; 38 RCTs high risk \\
& Blinding (outcome assessors): 10 RCTs low risk; 2 RCTs unclear risk; 37 RCTs high risk \\
& Incomplete outcome data: 45 RCTs low risk; 4 RCTs high risk \\
& Selective reporting: 9 RCTs low risk; 40 RCTs unclear risk \\
& Other: 23 RCTs low risk; 24 RCTs unclear risk; 2 RCTs high risk \\
& Overall: "Overall, the quality of the studies included in this review is moderate to poor" \\
\hline
\end{tabular}

Sequence generation: 3 RCTs low risk; 8 RCTs unclear risk; 2 RCTs high risk

Allocation concealment: 3 RCTs low risk; 6 RCTs unclear risk; 4 RCTs high risk

Blinding (participants and personnel): $13 \mathrm{RCTs}$ high risk

Blinding (outcome assessors): 12 RCTs unclear risk; 1 RCT high risk

Incomplete outcome data: 8 RCTs low risk; 3 RCTs unclear risk; 2 RCTs high risk

Selective reporting: 13 RCTs high risk

Other: 13 RCTs low risk

Overall: Only 2 RCTs were judged to be of high quality.

"The overall quality of the evidence can best be described as low to moderate"

Allocation concealment: 3 RCTs low risk; 1 RCT unclear risk

Blinding (participants and personnel): 1 RCT low risk; 3 RCTs unclear risk

Blinding (outcome assessors): 1 RCT low risk; 3 RCTs unclear risk

Incomplete outcome data: 1 RCT low risk; 2 RCTs unclear risk; 1 RCT high risk

Selective reporting: $4 \mathrm{RCTs}$ low risk

Other: 1 RCT low risk; 2 RCTs unclear; 1 RCT high risk

Overall: "Overall, two trials were judged to have a low risk of bias, one was unclear and one a high risk of bias" 
Table 3. Risk of bias assessments from included reviews (Continued)

Allocation concealment: 7 RCTs unclear risk; 1 RCT high risk

Blinding: 2 RCTs low risk; 1 RCT unclear risk; 5 RCTs high risk

Incomplete outcome data: 3 RCTs low risk; 4 RCTs unclear risk; 1 RCT high risk

Selective reporting: 6 RCTs low risk; 2 RCTs unclear risk

Other: 5 RCTs low risk; 2 RCTs unclear risk; 1 RCT high risk

Overall: "The trials were of variable quality."

Allocation concealment: 7 RCTs unclear risk; 1 RCT high risk; 1 RCT: not reported

Blinding: 4 RCTs low risk; 1 RCT unclear risk; 4 RCTs high risk

Incomplete outcome data: 1 RCT low risk; 5 RCTs unclear risk; 3 RCTs high risk

Selective reporting: 9 RCTs low risk

Other: 6 RCTs low risk; 1 RCT unclear risk; 2 RCTs high risk

Overall: "Poor-quality trials contribute excessively to the weight in the overall analysis due to the higher rate of adverse outcomes in those trials"

Allocation concealment: 6 RCTs low risk; 27 RCTs unclear risk; 4 RCTs high risk

Blinding (participants and personnel): 4 RCTs low risk; 7 RCTs unclear risk; 26 RCTs high risk

Blinding (outcome assessors): 1 RCT low risk; 35 RCTs unclear risk; 1 RCT high risk

Incomplete outcome data: 20 RCTs low risk; 15 RCTs unclear risk; 2 RCTs high risk

Selective reporting: 11 RCTs low risk; 19 RCTs unclear risk; 7 RCTs high risk

Other: 17 RCTs low risk; 20 RCTs unclear risk

Overall: "Overall, we judged the included trials to be of moderate to high risk of bias"

Allocation concealment: 10 RCTs low risk

Blinding (participants and personnel): 9 RCTs low risk; 1 RCT high risk

Blinding (outcome assessors): 4 RCTs low risk; 6 RCTs unclear risk

Incomplete outcome data: 7 RCTs low risk; 3 RCTs unclear risk

Selective reporting: 9 RCTs low risk; 1 RCT unclear risk

Other: 7 RCTs low risk; 3 RCTs high risk

Overall: "Overall, the included trials were assessed as having a low to moderate risk of bias"

Allocation concealment: 23 RCTs low risk; 13 RCTs unclear risk

Blinding (participants and personnel): 24 RCTs low risk; 7 RCTs unclear risk; 4 RCTs high risk

Blinding (outcome assessors): 15 RCTs low risk; 17 RCTs unclear risk; 4 RCTs high risk 
Table 3. Risk of bias assessments from included reviews (Continued)

Incomplete outcome data: 31 RCTs low risk; 5 RCTs unclear risk

Selective reporting: 25 RCTs low risk; 10 RCTs unclear risk; 1 RCT high risk

Other: 21 RCTs low risk; 15 RCTs unclear risk

Overall: "The overall quality of the included trials varied from good to fair"

Sequence generation: 4 RCTs low risk; 1 RCT unclear risk
Allocation concealment: 4 RCTs low risk; 1 RCT unclear risk
Blinding: 3 RCTs low risk; 2 RCT unclear risk
Incomplete outcome data: 2 RCTs low risk; 3 RCT unclear risk
Selective reporting: 4 RCTs low risk; 1 RCT unclear risk
Overall: "Overall, the methodological quality of the trials was relatively good, with a low risk of
bias. However, the quality was better, and the risk of bias lower, in some studies compared with
others"

Sequence generation: 6 RCTs low risk; 9 RCTs unclear risk

Allocation concealment: 5 RCTs low risk; 9 RCTs unclear risk; 1 RCT high risk

Blinding: 4 RCTs low risk; 3 RCTs unclear risk; 8 RCTs high risk

Incomplete outcome data: 7 RCTs low risk; 3 RCTs unclear risk; 5 RCTs high risk

Overall: "The quality of the studies included in this review ranged from excellent to poor. However, most of the poor quality studies were small. The large study comparing magnesium sulphate with placebo was of high quality"

Allocation concealment: 9 RCTs low risk; 5 RCTs unclear risk

Blinding (participants and personnel): 12 RCTs low risk; 2 RCTs high risk

Blinding (outcome assessors): 12 RCTs low risk; 2 RCTs high risk

Incomplete outcome data: 13 RCTs low risk; 1 RCT unclear risk (long-term: 1 RCT low risk; 13 RCTs unclear risk)

Selective reporting: 12 RCTs low risk; 2 RCTs unclear risk

Other: 13 RCTs low risk; 1 RCT unclear risk

Overall: "Overall the quality of the included trials was good"

Double blinding (of physicians and patients) for outcome assessment: 7 RCTs

For maternal and pregnancy outcomes, follow up of greater than $90 \%: 20$ RCTs

Overall: "The quality of these trials was poor" 
Table 3. Risk of bias assessments from included reviews (Continued)

Blinding (outcome assessors): 9 RCTs low risk; 8 RCTs unclear risk; 11 RCTs high risk

Incomplete outcome data: 16 RCTs low risk; 10 RCTs unclear risk; 2 RCTs high risk

Selective reporting: 1 RCT low risk; 26 RCTs unclear risk; 1 RCT high risk

Other: 8 RCTs low risk; 19 RCTs unclear risk; 1 RCT high risk

Overall: not detailed

Overall: not detailed

Sequence generation: 1 RCT low risk

Allocation concealment: 1 RCT low risk

Blinding (participants and personnel): 1 RCT high risk

Blinding (outcome assessors): 1 RCT low risk

Incomplete outcome data: 1 RCT low risk (high for childhood outcomes)

Selective reporting: $1 \mathrm{RCT}$ low risk

Other: 1 RCT high risk

Overall: "large study of good quality"

Abbreviation: RCT: randomised controlled trial 


\begin{tabular}{|c|c|c|c|c|c|c|c|c|c|c|c|c|}
\hline \multirow[t]{2}{*}{ Review ID } & \multicolumn{11}{|c|}{ AMSTAR criteria } & \multirow[t]{2}{*}{ Total score } \\
\hline & $\begin{array}{l}\text { A priori } \\
\text { design }\end{array}$ & $\begin{array}{l}\text { Dupli- } \\
\text { cate se- } \\
\text { lection } \\
\text { and ex- } \\
\text { traction }\end{array}$ & $\begin{array}{l}\text { Compre- } \\
\text { hensive } \\
\text { search }\end{array}$ & $\begin{array}{l}\text { Grey lit- } \\
\text { erature } \\
\text { consid- } \\
\text { ered }\end{array}$ & $\begin{array}{l}\text { Includ- } \\
\text { ed and } \\
\text { exclud- } \\
\text { ed stud- } \\
\text { ies lists }\end{array}$ & $\begin{array}{l}\text { Char- } \\
\text { acteris- } \\
\text { tics of } \\
\text { included } \\
\text { studies }\end{array}$ & $\begin{array}{l}\text { Quali- } \\
\text { ty as- } \\
\text { sessed } \\
\text { and doc- } \\
\text { ument- } \\
\text { ed }\end{array}$ & $\begin{array}{l}\text { Quality } \\
\text { consid- } \\
\text { ered for } \\
\text { conclu- } \\
\text { sions }\end{array}$ & $\begin{array}{l}\text { Methods } \\
\text { for com- } \\
\text { bining } \\
\text { studies } \\
\text { appro- } \\
\text { priate }\end{array}$ & $\begin{array}{l}\text { Publica- } \\
\text { tion bias } \\
\text { consid- } \\
\text { ered } \\
\text { or as- } \\
\text { sessed }\end{array}$ & $\begin{array}{l}\text { Con- } \\
\text { flicts } \\
\text { stated }\end{array}$ & \\
\hline Abalos 2014 & $\checkmark$ & $\checkmark$ & $\checkmark$ & $\checkmark$ & $\checkmark$ & $\checkmark$ & $\checkmark$ & $\checkmark$ & $\checkmark$ & $\checkmark$ & $\#$ & $\begin{array}{l}\text { 10/11 } \\
\text { HIGH QUALITY }\end{array}$ \\
\hline $\begin{array}{l}\text { Alfirevic } \\
2013\end{array}$ & $\checkmark$ & $\checkmark$ & $\checkmark$ & $\checkmark$ & $\checkmark$ & $\checkmark$ & $\checkmark$ & $\checkmark$ & $\checkmark$ & $\checkmark$ & $\#$ & $\begin{array}{l}\text { 10/11 } \\
\text { HIGH QUALITY }\end{array}$ \\
\hline $\begin{array}{l}\text { Churchill } \\
2013\end{array}$ & $\checkmark$ & $\checkmark$ & $\checkmark$ & $\checkmark$ & $\checkmark$ & $\checkmark$ & $\checkmark$ & $\checkmark$ & $\checkmark$ & $\checkmark$ & $\#$ & $\begin{array}{l}\text { 10/11 } \\
\text { HIGH QUALITY }\end{array}$ \\
\hline $\begin{array}{l}\text { Crowther } \\
2010\end{array}$ & $\checkmark$ & $\checkmark$ & $\checkmark$ & $\checkmark$ & $\checkmark$ & $\checkmark$ & $\checkmark$ & $\checkmark$ & $\checkmark$ & $\checkmark$ & $\#$ & $\begin{array}{l}\text { 10/11 } \\
\text { HIGH QUALITY }\end{array}$ \\
\hline $\begin{array}{l}\text { Crowther } \\
2010 a\end{array}$ & $\checkmark$ & $\checkmark$ & $\checkmark$ & $\checkmark$ & $\checkmark$ & $\checkmark$ & $\checkmark$ & $\checkmark$ & $\checkmark$ & $\checkmark$ & $\#$ & $\begin{array}{l}\text { 10/11 } \\
\text { HIGH QUALITY }\end{array}$ \\
\hline $\begin{array}{l}\text { Crowther } \\
2014\end{array}$ & $\checkmark$ & $\checkmark$ & $\checkmark$ & $\checkmark$ & $\checkmark$ & $\checkmark$ & $\checkmark$ & $\checkmark$ & $\checkmark$ & $\checkmark$ & $\checkmark$ & $\begin{array}{l}11 / 11 \\
\text { HIGH QUALITY }\end{array}$ \\
\hline $\begin{array}{l}\text { Crowther } \\
2015\end{array}$ & $\checkmark$ & $\checkmark$ & $\checkmark$ & $\checkmark$ & $\checkmark$ & $\checkmark$ & $\checkmark$ & $\checkmark$ & $\checkmark$ & $\checkmark$ & $\checkmark$ & $\begin{array}{l}11 / 11 \\
\text { HIGH QUALITY }\end{array}$ \\
\hline Dodd 2013 & $\checkmark$ & $\checkmark$ & $\checkmark$ & $\checkmark$ & $\checkmark$ & $\checkmark$ & $\checkmark$ & $\checkmark$ & $\checkmark$ & $\checkmark$ & $\#$ & $\begin{array}{l}\text { 10/11 } \\
\text { HIGH QUALITY }\end{array}$ \\
\hline Doyle 2009 & $\checkmark$ & $\checkmark$ & $\checkmark$ & $\checkmark$ & $\checkmark$ & $\checkmark$ & $\checkmark$ & $\checkmark$ & $\checkmark$ & $\#$ & $\#$ & $\begin{array}{l}\text { 9/11 } \\
\text { HIGH QUALITY }\end{array}$ \\
\hline Duley 2010 & $\checkmark$ & $\checkmark$ & $\checkmark$ & $\checkmark$ & $\checkmark$ & $\checkmark$ & $\checkmark$ & $\checkmark$ & $?$ & $\#$ & $\#$ & $8 / 11$ \\
\hline
\end{tabular}







Table 5. ROBIS assessments for included reviews

\begin{tabular}{|c|c|c|c|c|c|}
\hline \multirow[t]{2}{*}{ Review ID } & \multicolumn{4}{|l|}{ ROBIS domains } & \multirow{2}{*}{$\begin{array}{l}\text { Overall risk of } \\
\text { bias }\end{array}$} \\
\hline & $\begin{array}{l}\text { Study eligibility } \\
\text { criteria }\end{array}$ & $\begin{array}{l}\text { Identification and } \\
\text { selection of stud- } \\
\text { ies }\end{array}$ & $\begin{array}{l}\text { Data collection } \\
\text { and study ap- } \\
\text { praisal }\end{array}$ & $\begin{array}{l}\text { Synthesis and } \\
\text { findings }\end{array}$ & \\
\hline Abalos 2014 & Low risk & Low risk & Low risk & Low risk & LOW RISK \\
\hline Alfirevic 2013 & Low risk & Low risk & Low risk & Low risk & LOW RISK \\
\hline Churchill 2013 & Low risk & Low risk & Low risk & Low risk & LOW RISK \\
\hline Crowther 2010 & Low risk & Low risk & Low risk & Low risk & LOW RISK \\
\hline Crowther 2010a & Low risk & Low risk & Low risk & Low risk & LOW RISK \\
\hline Crowther 2014 & Low risk & Low risk & Low risk & Low risk & LOW RISK \\
\hline Crowther 2015 & Low risk & Low risk & Low risk & Low risk & LOW RISK \\
\hline Dodd 2013 & Low risk & Low risk & Low risk & Low risk & LOW RISK \\
\hline Doyle 2009 & Low risk & Low risk & Low risk & Low risk & LOW RISK \\
\hline Duley 2010 & Low risk & Low risk & Low risk & Unclear risk & LOW RISK \\
\hline Flenady 2013 & Low risk & Low risk & Low risk & Low risk & LOW RISK \\
\hline Magee 2003 & Low risk & Low risk & Low risk & Unclear risk & LOW RISK \\
\hline Neilson 2014 & Low risk & Low risk & Low risk & Low risk & LOW RISK \\
\hline Roberts 2006 & Low risk & Low risk & Low risk & Unclear risk & LOW RISK \\
\hline Stock 2016 & Low risk & Low risk & Low risk & Low risk & LOW RISK \\
\hline
\end{tabular}


Table 6. Summary of findings: all comparisons measuring cerebral palsy

\begin{tabular}{|c|c|c|c|c|c|c|}
\hline $\begin{array}{l}\text { Intervention and } \\
\text { comparison }\end{array}$ & Outcome & $\begin{array}{l}\text { Assumed risk } \\
\text { with com- } \\
\text { parator }\end{array}$ & $\begin{array}{l}\text { Correspond- } \\
\text { ing risk with } \\
\text { intervention }\end{array}$ & $\begin{array}{l}\text { Relative ef- } \\
\text { fect }(95 \% \mathrm{Cl})\end{array}$ & $\begin{array}{l}\text { Number of } \\
\text { participants } \\
\text { (trials) }\end{array}$ & $\begin{array}{l}\text { Quality of } \\
\text { the evidence } \\
\text { (GRADE) }\end{array}$ \\
\hline
\end{tabular}

Interventions for the treatment of mild to moderate hypertension tensive drug ver-

Cerebral palsy at 1 year (definition not

18 per 1000

6 per $1000(0$

RR 0.33 (95\%

$110(1 \mathrm{RCT})$

VERY LOW

study limitations clear; one child with 'spastic quadri-
paresis with a severe pseudo-bulbar pal- $\quad(1 / 55)$

to 146$)$

8.01)

mild to moder-

sy') assessed by clinical evaluation

ate hypertension

during pregnancy (assessment method taken from RCT

(Abalos 2014)

manuscript as not detailed in reviews)

and

Oral beta-block-

ers versus place-

bo for mild to

moderate hy-

pertension dur-

ing pregnancy

(Magee 2003)

\section{Interventions for the treatment of pre-eclampsia}

Intervention- Cerebral palsy at 2 years (definition not

ist care versus clear) assessed by family practitioner or

layed delivery)

paediatrician using short questionnaire

8 per 1000

50 per $1000(6$

$(1 / 121)$

to 398 )

RR 6.01 (95\%

$262(1 \mathrm{RCT})$

LOW

48.14)

(assessment method taken from RCT

care for severe

pre-eclampsia

(Churchill 2013)

manuscript as not detailed in review)

imprecision (-2):

wide confidence

intervals crossing

line of no effect; 1

small RCT with few

events

\section{Magnesium Severe cerebral palsy at 18 months}

sulphate ver-

sus placebo for

women with pre-

defined as 'not walking or unlikely to

walk unaided by 24 months; children

6 per 1000

2 per $1000(1$

RR 0.34 (95\%

$2895(1 \mathrm{RCT})$

LOW

screened with Ages and Stages Ques-

(9/1464)

to 8$)$

$\mathrm{Cl} 0.09$ to

eclampsia (Duley tionnaires; screen-positive and a sam-

2010)

ple of screen-negative children had clin-

ical and neurodevelopmental assess-

ments (using Bayley Scales of Infant De-

velopment; Griffiths Tests, or other); if

this was not possible, clinical history

study limitations

$(-1)$ : 1 RCT with un-

clear risk of attri-

tion bias for this

outcome (2895 of

6922 children in-

cluded in original

$\mathrm{RCT}$ )

imprecision (-1): wide confidence 


\begin{tabular}{|c|c|c|c|c|c|c|c|}
\hline & $\begin{array}{l}\text { and examination (using the Health Sta- } \\
\text { tus Questionnaire) } \\
\text { (definition and assessment method tak- } \\
\text { en from RCT manuscript as not detailed } \\
\text { in review) }\end{array}$ & & & & & & $\begin{array}{l}\text { intervals crossing } \\
\text { line of no effect }\end{array}$ \\
\hline \multicolumn{8}{|c|}{ Interventions for the diagnosis and prevention of fetal compromise in labour } \\
\hline $\begin{array}{l}\text { Continuous car- } \\
\text { diotocography } \\
\text { (CTG) versus in- } \\
\text { termittent aus- } \\
\text { cultation (IA) for } \\
\text { fetal assessment } \\
\text { during labour (Al- } \\
\text { firevic 2013) }\end{array}$ & $\begin{array}{l}\text { Cerebral palsy at } 18 \text { months to } 4 \text { years } \\
\text { - } 1 \text { RCT: defined as 'non-progressive } \\
\text { disorder of movement or posture due } \\
\text { to a defect in or damage to the devel- } \\
\text { oping brain'; a developmental paedia- } \\
\text { trician performed neurological exam- } \\
\text { inations at } 18 \text { months } \\
\text { - } 1 \text { RCT: definition not clear; children } \\
\text { with abnormal neurological signs in } \\
\text { the neonatal period underwent a gen- } \\
\text { eral physical and detailed neurologi- } \\
\text { cal examination by a paediatrician at } \\
4 \text { years; other cases identified from } \\
\text { records of specialist remedial clinics } \\
\text { (definitions and assessment methods } \\
\text { taken from RCT manuscripts as not de- } \\
\text { tailed in review) }\end{array}$ & $\begin{array}{l}3 \text { per } 1000 \\
(17 / 6643)\end{array}$ & $\begin{array}{l}4 \text { per } 1000(2 \\
\text { to } 9)\end{array}$ & $\begin{array}{l}\text { average RR } \\
1.75(95 \% 0.84 \\
\text { to } 3.63)\end{array}$ & $\begin{array}{l}13,252 \text { (2 } \\
\text { RCTs) }\end{array}$ & LOW & $\begin{array}{l}\text { quality of evidence } \\
\text { (GRADE), taken } \\
\text { from published re- } \\
\text { view: } \\
\text { "study limitations } \\
\text { (-1): most of the } \\
\text { pooled effect pro- } \\
\text { vided by studies } \\
\text { "B" or "C" without } \\
\text { a substantial pro- } \\
\text { portion (i.e. < 40\% } \\
\text { (actual } 0 \% \text { weight) } \\
\text { from studies "C" } \\
\text { imprecision (-1): } \\
95 \% \text { confidence in- } \\
\text { terval around the } \\
\text { pooled or best es- } \\
\text { timate of effect in- } \\
\text { cludes both 1) no } \\
\text { effect and 2) ap- } \\
\text { preciable benefit } \\
\text { favouring IA" }\end{array}$ \\
\hline \multicolumn{8}{|c|}{ Interventions for the prevention of preterm birth } \\
\hline $\begin{array}{l}\text { Prenatal admin- } \\
\text { istration of prog- } \\
\text { esterone versus } \\
\text { placebo for pre- } \\
\text { venting preterm } \\
\text { birth in women } \\
\text { with a previous } \\
\text { history sponta- } \\
\text { neous preterm }\end{array}$ & $\begin{array}{l}\text { Cerebral palsy at } 4 \text { years, definition not } \\
\text { clear; assessed by general physical ex- } \\
\text { amination by paediatrician or nurse } \\
\text { practitioner, or from chart abstraction } \\
\text { (age and assessment method taken } \\
\text { from RCT manuscript as not detailed in } \\
\text { review) }\end{array}$ & $\begin{array}{l}12 \text { per } 1000 \\
(1 / 82)\end{array}$ & $\begin{array}{l}2 \text { per } 1000(0 \\
\text { to } 42)\end{array}$ & $\begin{array}{l}\text { RR } 0.14(95 \% \\
0.01 \text { to } 3.48)\end{array}$ & $274(1 \mathrm{RCT})$ & LOW & $\begin{array}{l}\text { imprecision }(-2) \text { : } \\
\text { wide confidence } \\
\text { intervals crossing } \\
\text { line of no effect; } 1 \\
\text { small RCT with few } \\
\text { events }\end{array}$ \\
\hline
\end{tabular}




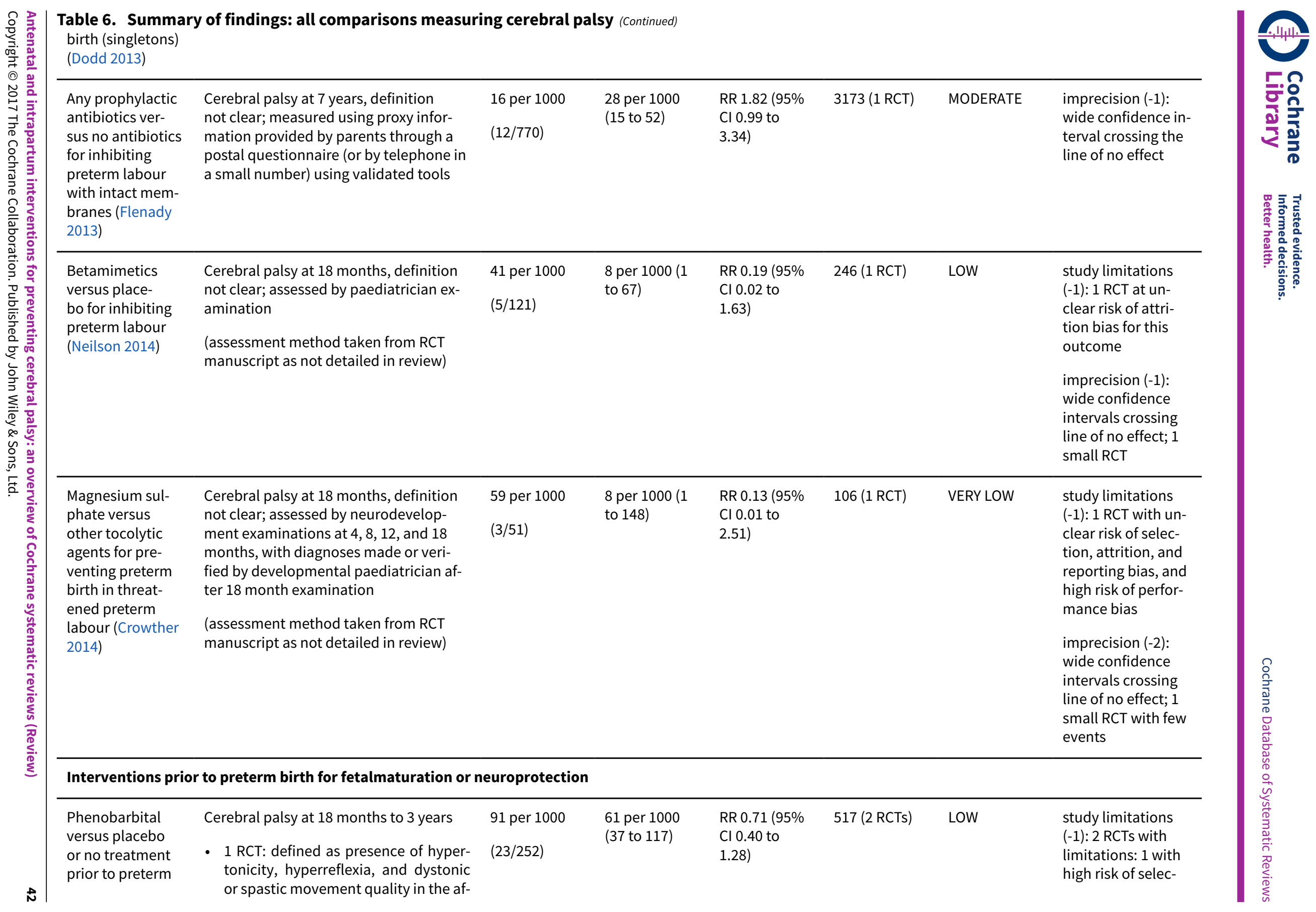




\begin{tabular}{|c|c|c|c|c|c|c|c|c|}
\hline $\begin{array}{l}\text { birth for pre- } \\
\text { venting neona- } \\
\text { tal periventricu- } \\
\text { lar haemorrhage } \\
\text { (Crowther 2010a) }\end{array}$ & $\begin{array}{l}\text { fected extremity (including diplegia, } \\
\text { hemiplegia, triplegia, or quadripleg- } \\
\text { ia); assessed by certified examiners } \\
\text { trained to perform neurologic exami- } \\
\text { nations at } 18 \text { months } \\
\text { - } 1 \text { RCT: described as cerebral palsy as- } \\
\text { sociated with motor delay (diplegia, } \\
\text { monoplegia, quadriplegia, and hemi- } \\
\text { plegia); assessed by trained nurse } \\
\text { practitioner using detailed physical } \\
\text { and neurologic examination at } 3 \text { years } \\
\text { (definitions and assessment methods } \\
\text { taken from RCT manuscript as not de- } \\
\text { tailed in review) }\end{array}$ & & & & & & $\begin{array}{l}\text { tion bias, bias due } \\
\text { to lack of blinding } \\
\text { and attrition bias; } 2 \\
\text { with unclear risk of } \\
\text { selection bias } \\
\text { imprecision (-1): } \\
\text { wide confidence } \\
\text { intervals crossing } \\
\text { line of no effect }\end{array}$ & 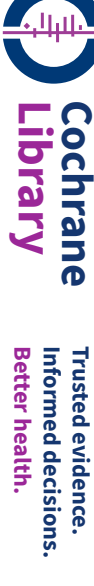 \\
\hline $\begin{array}{l}\text { Vitamin K ver- } \\
\text { sus placebo prior } \\
\text { to preterm birth } \\
\text { for preventing } \\
\text { neonatal periven- } \\
\text { tricular haemor- } \\
\text { rhage (Crowther } \\
\text { 2010) } \\
\text { and } \\
\text { Phenobarbital } \\
\text { versus placebo } \\
\text { prior to preterm } \\
\text { birth for pre- } \\
\text { venting neona- } \\
\text { tal periventricu- } \\
\text { lar haemorrhage } \\
\text { (Crowther 2010a) }\end{array}$ & $\begin{array}{l}\text { Cerebral palsy at } 7 \text { years, definition not } \\
\text { clear; method of assessment not clear }\end{array}$ & $\begin{array}{l}79 \text { per } 1000 \\
(12 / 151)\end{array}$ & $\begin{array}{l}61 \text { per } 1000 \\
(26 \text { to } 140)\end{array}$ & $\begin{array}{l}\text { RR } 0.77(95 \% \\
\mathrm{Cl} 0.33 \text { to } \\
1.76)\end{array}$ & 299 (1 RCT) & VERY LOW & $\begin{array}{l}\text { study limitations } \\
(-1): 1 \text { RCT with un- } \\
\text { clear risk of selec- } \\
\text { tion bias, and high } \\
\text { risk of attrition bias } \\
\text { indirectness }(-1) \text { : } \\
\text { dual intervention } \\
\text { of vitamin K and } \\
\text { phenobarbital } \\
\text { imprecision }(-1) \text { : } \\
\text { wide confidence } \\
\text { intervals crossing } \\
\text { line of no effect }\end{array}$ & 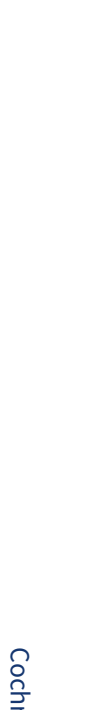 \\
\hline $\begin{array}{l}\text { Magnesium } \\
\text { sulphate ver- } \\
\text { sus placebo for } \\
\text { women at risk } \\
\text { of preterm birth } \\
\text { for neuroprotec- } \\
\text { tion of the fetus } \\
\text { (Doyle 2009) }\end{array}$ & $\begin{array}{l}\text { Cerebral palsy at } 18 \text { months to } 2 \text { years } \\
\text { - } 1 \text { RCT: defined as abnormalities of } \\
\text { tone and loss of motor function; as- } \\
\text { sessed by developmental paediatri- } \\
\text { cian at } 2 \text { years } \\
\text { - } 1 \text { RCT: defined severe cerebral pal- } \\
\text { sy as not walking or unlikely to } \\
\text { walk unaided by } 2 \text { years; children } \\
\text { screened with Ages and Stages Ques- }\end{array}$ & $\begin{array}{l}50 \text { per } 1000 \\
(154 / 3093)\end{array}$ & $\begin{array}{l}34 \text { per } 1000 \\
(27 \text { to } 43)\end{array}$ & $\begin{array}{l}\text { RR } 0.68(95 \% \\
\mathrm{Cl} 0.54 \text { to } \\
0.87)\end{array}$ & 6145 (5 RCTs) & $\mathrm{HIGH}$ & Not downgraded & 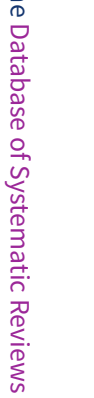 \\
\hline
\end{tabular}




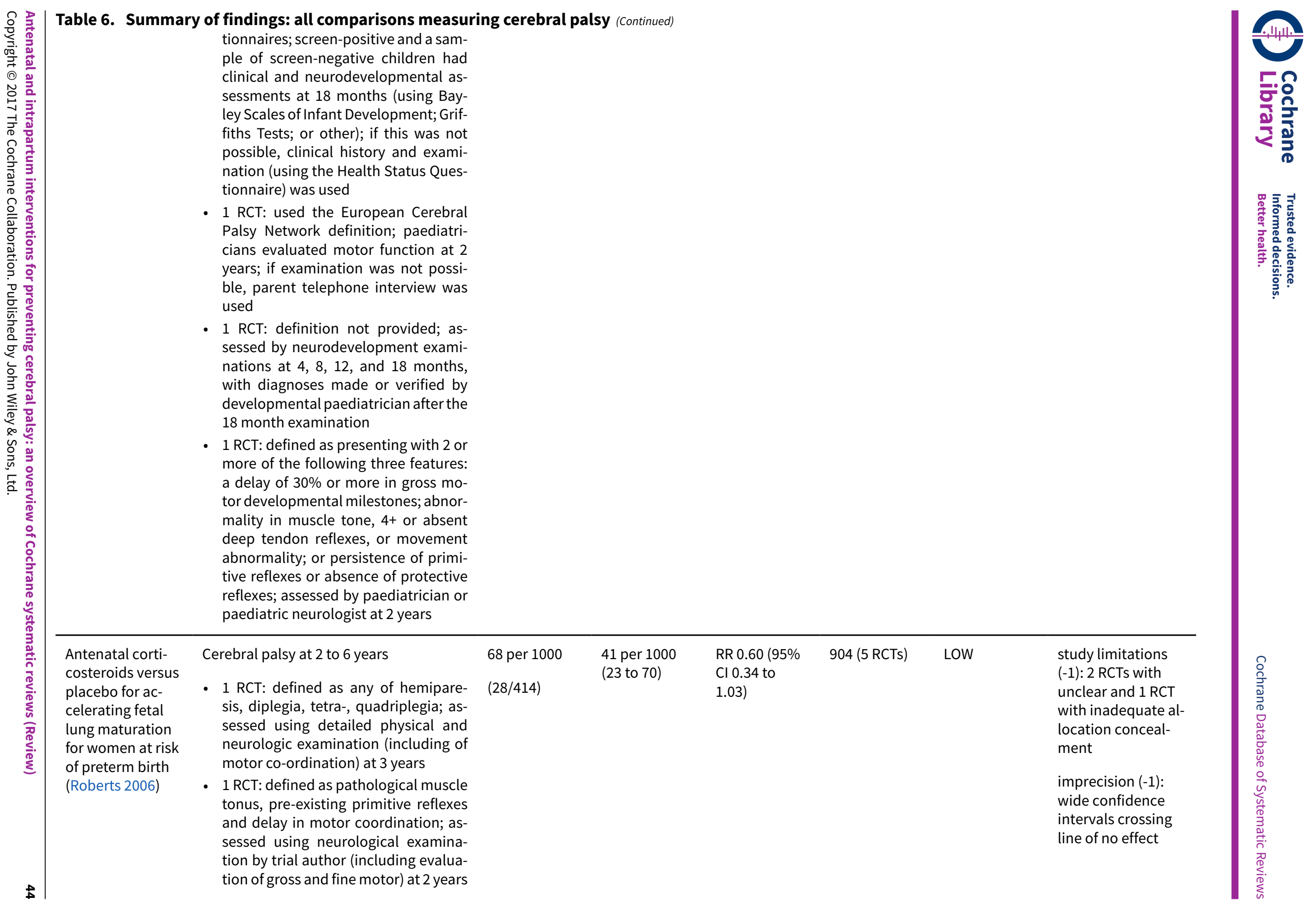


Interventions for the management of preterm fetalcompromise 


\begin{tabular}{|c|c|c|c|c|c|c|c|c|c|c|}
\hline $\begin{array}{l}\text { Immediate versus } \\
\text { deferred delivery } \\
\text { of the preterm } \\
\text { baby with sus- } \\
\text { pected fetal com- } \\
\text { promise (Stock } \\
\text { 2016) }\end{array}$ & \multicolumn{3}{|c|}{$\begin{array}{l}\text { Cerebral palsy at or after } 2 \text { years } \\
\text { definition not clear; assessed by family } \\
\text { practitioner or paediatrician using short } \\
\text { questionnaire } \\
\text { (assessment method taken from RCT } \\
\text { manuscript as not detailed in review) }\end{array}$} & $\begin{array}{l}8 \text { per } 1000 \\
(2 / 251)\end{array}$ & \multicolumn{2}{|c|}{$\begin{array}{l}47 \text { per } 1000 \\
(11 \text { to } 207)\end{array}$} & $\begin{array}{l}\mathrm{RR} 5.88(\mathrm{Cl} \\
95 \% 1.33 \text { to } \\
26.02)\end{array}$ & $507(1 \mathrm{RCT})$ & MODERATE & \multirow[t]{2}{*}{$\begin{array}{l}\text { study limitations } \\
(-1): 1 \text { RCT at high } \\
\text { risk of performance } \\
\text { bias and other bias } \\
\text { (did not account } \\
\text { for non-indepen- } \\
\text { dence of data for } \\
\text { twin pregnancies) }\end{array}$} \\
\hline \multicolumn{10}{|c|}{ Abbreviations: $\mathrm{Cl}$ : confidence intervals; IA: intermittent auscultation; RCT: randomised controlled trial; RR: risk ratio; $\mathrm{Cl}$ : confidence interval } & \\
\hline $\begin{array}{l}\text { Intervention and } \\
\text { comparison }\end{array}$ & Outcome & $\begin{array}{l}\text { Subgroup o } \\
\text { sis }\end{array}$ & ensitiv & y analy- & $\begin{array}{l}\text { Assumed } \\
\text { risk with } \\
\text { comparator }\end{array}$ & & $\begin{array}{l}\text { esponding } \\
\text { with inter- } \\
\text { ion }\end{array}$ & Relative effect $(95 \% \mathrm{Cl})$ & $\begin{array}{l}\text { Number } \\
\text { of partici- } \\
\text { pants (tri- } \\
\text { als) }\end{array}$ & $\begin{array}{l}\text { Test for sub- } \\
\text { group differ- } \\
\text { ences }\end{array}$ \\
\hline \multicolumn{11}{|c|}{ Interventions for the diagnosis and prevention of fetalcompromise in labour } \\
\hline \multirow{7}{*}{$\begin{array}{l}\text { Continuous car- } \\
\text { diotocography (CTG) } \\
\text { versus intermittent } \\
\text { auscultation (IA) for } \\
\text { fetal assessment } \\
\text { during labour (Alfire- } \\
\text { vic 2013) }\end{array}$} & \multirow{7}{*}{$\begin{array}{l}\text { Cerebral } \\
\text { palsy at } 18 \\
\text { months to } 4 \\
\text { years }\end{array}$} & \multirow[t]{2}{*}{$\begin{array}{l}\text { Pregnancy } \\
\text { risk status }\end{array}$} & \multicolumn{2}{|l|}{ High } & 77 per 1000 & \multicolumn{2}{|c|}{$\begin{array}{l}195 \text { per } 1000 \\
\text { (85 to } 451)\end{array}$} & $\begin{array}{l}\text { RR } 2.54(95 \% \mathrm{Cl} 1.10 \text { to } \\
5.86)\end{array}$ & $173(1 \mathrm{RCT})$ & \multirow{2}{*}{$\begin{array}{l}\mathrm{Chi}^{2}=1.52, \mathrm{df}= \\
1(\mathrm{P}=0.22), \mathrm{I}^{2}= \\
34 \%\end{array}$} \\
\hline & & & \multicolumn{2}{|c|}{$\begin{array}{l}\text { Mixed or not } \\
\text { specified }\end{array}$} & 2 per 1000 & \multicolumn{2}{|c|}{$\begin{array}{l}2 \text { per } 1000 \text { ( } 1 \text { to } \\
4)\end{array}$} & $\begin{array}{l}\mathrm{RR} 1.20(95 \% \mathrm{Cl} 0.52 \text { to } \\
2.79)\end{array}$ & $\begin{array}{l}13079(1 \\
\mathrm{RCT})\end{array}$ & \\
\hline & & $\begin{array}{l}\text { Onset of } \\
\text { labour }\end{array}$ & \multicolumn{2}{|c|}{ Not specified } & 3 per 1000 & \multicolumn{2}{|c|}{$\begin{array}{l}4 \text { per } 1000 \text { ( } 2 \text { to } \\
8)\end{array}$} & $\begin{array}{l}\mathrm{RR} 1.74(95 \% \mathrm{Cl} 0.97 \text { to } \\
3.11)\end{array}$ & $\begin{array}{l}13,252(2 \\
\text { RCTs) }\end{array}$ & Not applicable \\
\hline & & $\begin{array}{l}\text { Gestational } \\
\text { age }\end{array}$ & \multicolumn{2}{|c|}{ Preterm labour } & 77 per 1000 & & $\begin{array}{l}\text { per } 1000 \\
\text { o 451) }\end{array}$ & $\begin{array}{l}\text { RR } 2.54(95 \% \mathrm{Cl} 1.10 \text { to } \\
5.86)\end{array}$ & $173(1 \mathrm{RCT})$ & \multirow{2}{*}{$\begin{array}{l}\mathrm{Chi}^{2}=1.52, \mathrm{df}= \\
1(\mathrm{P}=0.22), \mathrm{I}^{2}= \\
34 \%\end{array}$} \\
\hline & & & \multicolumn{2}{|c|}{$\begin{array}{l}\text { Both or gestation } \\
\text { not specified }\end{array}$} & 2 per 1000 & \multicolumn{2}{|c|}{$\begin{array}{l}2 \text { per } 1000 \text { ( } 1 \text { to } \\
4)\end{array}$} & $\begin{array}{l}\mathrm{RR} 1.20(95 \% \mathrm{Cl} 0.52 \text { to } \\
2.79)\end{array}$ & $\begin{array}{l}13,079(1 \\
\mathrm{RCT})\end{array}$ & \\
\hline & & $\begin{array}{l}\text { Number of } \\
\text { babies }\end{array}$ & \multicolumn{2}{|c|}{ Singleton } & 77 per 1000 & & $\begin{array}{l}\text { er } 1000 \\
\text { 451) }\end{array}$ & $\begin{array}{l}\text { RR } 2.54(95 \% \mathrm{Cl} 1.10 \text { to } \\
5.86)\end{array}$ & 173 (1 RCT) & \multirow{2}{*}{$\begin{array}{l}\mathrm{Chi}^{2}=1.52, \mathrm{df} \\
=1(\mathrm{P}=0.22), \mathrm{I}^{2} \\
=34 \%\end{array}$} \\
\hline & & & \multicolumn{2}{|c|}{$\begin{array}{l}\text { Both or not spec- } \\
\text { ified }\end{array}$} & 2 per 1000 & \multicolumn{2}{|c|}{$\begin{array}{l}2 \text { per } 1000 \text { ( } 1 \text { to } \\
4)\end{array}$} & $\begin{array}{l}\text { RR } 1.20(95 \% \mathrm{Cl} 0.52 \text { to } \\
2.79)\end{array}$ & $\begin{array}{l}13,079(1 \\
\mathrm{RCT})\end{array}$ & \\
\hline
\end{tabular}




\begin{tabular}{|c|c|c|c|c|c|c|c|c|}
\hline & & $\begin{array}{l}\text { Access to } \\
\text { fetal blood } \\
\text { sampling }\end{array}$ & Yes & 3 per 1000 & $\begin{array}{l}4 \text { per } 1000 \text { ( } 2 \text { to } \\
8)\end{array}$ & $\begin{array}{l}\text { RR } 1.74 \text { (95\% Cl } 0.97 \text { to } \\
3.11)\end{array}$ & $\begin{array}{l}13,252(2 \\
\text { RCTs) }\end{array}$ & Not applicable \\
\hline & & Parity & $\begin{array}{l}\text { Both or not spec- } \\
\text { ified }\end{array}$ & 3 per 1000 & $\begin{array}{l}4 \text { per } 1000 \text { ( } 2 \text { to } \\
8)\end{array}$ & $\begin{array}{l}\text { RR } 1.74 \text { (95\% Cl } 0.97 \text { to } \\
3.11)\end{array}$ & $\begin{array}{l}13,252(2 \\
\text { RCTs) }\end{array}$ & Not applicable \\
\hline & & Quality & High & 2 per 1000 & $\begin{array}{l}2 \text { per } 1000 \text { ( } 1 \text { to } \\
4)\end{array}$ & $\begin{array}{l}\text { RR } 1.20 \text { (95\% Cl } 0.52 \text { to } \\
2.79)\end{array}$ & $\begin{array}{l}13,079(1 \\
\mathrm{RCT})\end{array}$ & \multirow{2}{*}{$\begin{array}{l}\text { Chi }^{2}=1.52, \mathrm{df}= \\
1(\mathrm{P}=0.22), \mathrm{I}^{2}= \\
34 \%\end{array}$} \\
\hline & & & Unclear & 77 per 1000 & $\begin{array}{l}195 \text { per } 1000 \\
(85 \text { to } 451)\end{array}$ & $\begin{array}{l}\text { RR } 2.54 \text { (95\% Cl } 1.10 \text { to } \\
5.86)\end{array}$ & $173(1 \mathrm{RCT})$ & \\
\hline \multicolumn{9}{|c|}{ Interventions for the prevention of preterm birth } \\
\hline $\begin{array}{l}\text { Prenatal adminis- } \\
\text { tration of proges- } \\
\text { terone versus place- } \\
\text { bo for preventing } \\
\text { preterm birth in } \\
\text { women with a previ- } \\
\text { ous history sponta- } \\
\text { neous preterm birth } \\
\text { (singletons) (Dodd } \\
\text { 2013) }\end{array}$ & $\begin{array}{l}\text { Cerebral } \\
\text { palsy at } 4 \\
\text { years }\end{array}$ & $\begin{array}{l}\text { Route of ad- } \\
\text { ministration }\end{array}$ & Intramuscular & 12 per 1000 & $\begin{array}{l}2 \text { per } 1000 \text { (0 to } \\
42)\end{array}$ & $\begin{array}{l}\text { RR } 0.14 \text { (95\% Cl } 0.01 \text { to } \\
3.48)\end{array}$ & $274(1 \mathrm{RCT})$ & Not applicable \\
\hline \multirow{3}{*}{$\begin{array}{l}\text { Prophylactic antibi- } \\
\text { otics versus no an- } \\
\text { tibiotics for inhibit- } \\
\text { ing preterm labour } \\
\text { with intact mem- } \\
\text { branes (Flenady } \\
\text { 2013) }\end{array}$} & $\begin{array}{l}\text { Cerebral } \\
\text { palsy at } 7 \\
\text { years }\end{array}$ & $\begin{array}{l}\text { Type of an- } \\
\text { tibiotic }\end{array}$ & $\begin{array}{l}\text { Beta-lactam an- } \\
\text { tibiotics alone }\end{array}$ & 16 per 1000 & $\begin{array}{l}19 \text { per } 1000(6 \\
\text { to } 57)\end{array}$ & $\begin{array}{l}\text { Average RR } 1.22(95 \% \mathrm{Cl} \\
0.41 \text { to } 3.63)\end{array}$ & $1049(1 \mathrm{RCT})$ & \multirow[t]{3}{*}{$\begin{array}{l}\mathrm{Chi}^{2}=1.41, \mathrm{df}= \\
2(\mathrm{P}=0.49), \mathrm{I}^{2}= \\
0.0 \%\end{array}$} \\
\hline & & & $\begin{array}{l}\text { Macrolide antibi- } \\
\text { otics alone }\end{array}$ & 16 per 1000 & $\begin{array}{l}22 \text { per } 1000(7 \\
\text { to } 65)\end{array}$ & $\begin{array}{l}\text { Average RR } 1.42(95 \% \mathrm{Cl} \\
0.48 \text { to } 4.15)\end{array}$ & 1073 (1 RCT) & \\
\hline & & & $\begin{array}{l}\text { Macrolide and } \\
\text { beta-lactam an- } \\
\text { tibiotics }\end{array}$ & 16 per 1000 & $\begin{array}{l}44 \text { per } 1000(16 \\
\text { to } 123)\end{array}$ & $\begin{array}{l}\text { Average RR } 2.83(95 \% \mathrm{Cl} \\
1.02 \text { to } 7.88)\end{array}$ & 1052 (1 RCT) & \\
\hline $\begin{array}{l}\text { Any macrolide ver- } \\
\text { sus no macrolide for } \\
\text { inhibiting preterm } \\
\text { labour with intact } \\
\text { membranes (Flenady } \\
\text { 2013) }\end{array}$ & & \multicolumn{2}{|c|}{$\begin{array}{l}\text { Any macrolide versus no } \\
\text { macrolide antibiotics }\end{array}$} & 17 per 1000 & $\begin{array}{l}33 \text { per } 1000(21 \\
\text { to } 52)\end{array}$ & $\begin{array}{l}\text { RR } 1.90 \text { (95\% Cl } 1.20 \text { to } \\
3.01)\end{array}$ & $3173(1 \mathrm{RCT})$ & Not applicable \\
\hline
\end{tabular}




\begin{tabular}{|c|c|c|c|c|c|c|c|c|}
\hline \multicolumn{2}{|l|}{$\begin{array}{l}\text { Any beta-lactam } \\
\text { versus no beta-lac- } \\
\text { tam for inhibiting } \\
\text { preterm labour with } \\
\text { intact membranes } \\
\text { (Flenady 2013) }\end{array}$} & \multicolumn{2}{|c|}{$\begin{array}{l}\text { Any beta-lactam versus no be- } \\
\text { ta-lactam antibiotics }\end{array}$} & 19 per 1000 & $\begin{array}{l}32 \text { per } 1000(20 \\
\text { to } 49)\end{array}$ & $\begin{array}{l}\mathrm{RR} 1.67 \text { (95\% } \mathrm{Cl} 1.06 \text { to } \\
2.61)\end{array}$ & $3173(1 \mathrm{RCT})$ & Not applicable \\
\hline \multicolumn{9}{|c|}{ Interventions prior to preterm birth for fetal maturation or neuroprotection } \\
\hline $\begin{array}{l}\text { Phenobarbital ver- } \\
\text { sus placebo prior } \\
\text { to preterm birth for } \\
\text { preventing neona- } \\
\text { tal periventricu- } \\
\text { lar haemorrhage } \\
\text { (Crowther 2010a) }\end{array}$ & $\begin{array}{l}\text { Cerebral } \\
\text { palsy at } 18 \\
\text { months to } 3 \\
\text { years }\end{array}$ & \multicolumn{2}{|c|}{$\begin{array}{l}\text { Excluding trials with non-con- } \\
\text { cealment at randomisation (C } \\
\text { quality) }\end{array}$} & 91 per 1000 & $\begin{array}{l}61 \text { per } 1000(37 \\
\text { to } 117)\end{array}$ & $\begin{array}{l}\mathrm{RR} 0.71(95 \% \mathrm{Cl} 0.40 \text { to } \\
1.28)\end{array}$ & 517 (2 RCTs) & Not applicable \\
\hline $\begin{array}{l}\text { Vitamin K versus } \\
\text { placebo prior to } \\
\text { preterm birth for } \\
\text { preventing neona- } \\
\text { tal periventricu- } \\
\text { lar haemorrhage } \\
\text { (Crowther 2010) } \\
\text { and } \\
\text { Phenobarbital ver- } \\
\text { sus placebo prior } \\
\text { to preterm birth for } \\
\text { preventing neona- } \\
\text { tal periventricu- } \\
\text { lar haemorrhage } \\
\text { (Crowther 2010a) }\end{array}$ & $\begin{array}{l}\text { Cerebral } \\
\text { palsy at } 7 \\
\text { years }\end{array}$ & \multicolumn{2}{|c|}{$\begin{array}{l}\text { Excluding trials with inadequate } \\
\text { concealment of allocation of } \\
\text { treatment }\end{array}$} & 79 per 1000 & $\begin{array}{l}61 \text { per } 1000(26 \\
\text { to } 140)\end{array}$ & $\begin{array}{l}\mathrm{RR} 0.77(95 \% \mathrm{Cl} 0.33 \text { to } \\
1.76)\end{array}$ & $299(1 \mathrm{RCT})$ & Not applicable \\
\hline \multirow{3}{*}{$\begin{array}{l}\text { Magnesium sulphate } \\
\text { versus placebo for } \\
\text { women at risk of } \\
\text { preterm birth for } \\
\text { neuroprotection } \\
\text { of the fetus (Doyle } \\
\text { 2009) }\end{array}$} & \multirow{3}{*}{$\begin{array}{l}\text { Cerebral } \\
\text { palsy be- } \\
\text { tween } 18 \\
\text { and } 2 \text { years }\end{array}$} & \multirow{3}{*}{$\begin{array}{l}\text { neuropro- } \\
\text { tective in- } \\
\text { tent }\end{array}$} & Neuroprotective & 65 per 1000 & $\begin{array}{l}46 \text { per } 1000(36 \\
\text { to } 59)\end{array}$ & $\begin{array}{l}\mathrm{RR} 0.71(95 \% \mathrm{Cl} 0.55 \text { to } \\
0.91)\end{array}$ & $\begin{array}{l}4446(4 \\
\text { RCTs) }\end{array}$ & \multirow{3}{*}{$\begin{array}{l}\text { Chi }^{2}=1.69, \mathrm{df}= \\
2(\mathrm{P}=0.43), \mathrm{I}^{2}= \\
0 \% \\
\text { (Performed by } \\
\text { overview au- } \\
\text { thors) }\end{array}$} \\
\hline & & & $\begin{array}{l}\text { Maternal neuro- } \\
\text { protective (pre- } \\
\text { eclampsia) }\end{array}$ & 6 per 1000 & $\begin{array}{l}3 \text { per } 1000 \text { ( } 1 \text { to } \\
13)\end{array}$ & $\begin{array}{l}\mathrm{RR} 0.40 \text { ( } 95 \% \mathrm{Cl} 0.08 \text { to } \\
2.05)\end{array}$ & $1593(1 \mathrm{RCT})$ & \\
\hline & & & Tocolytic & 59 per 1000 & $\begin{array}{l}7 \text { per } 1000 \text { ( } 1 \text { to } \\
148)\end{array}$ & $\begin{array}{l}\text { RR } 0.13(95 \% \mathrm{Cl} 0.01 \text { to } \\
2.51)\end{array}$ & $106(1 \mathrm{RCT})$ & \\
\hline
\end{tabular}


Table 7. Summary of findings: subgroup or sensitivity analyses of select comparisons for cerebral palsy (Continued)

\begin{tabular}{|c|c|c|c|c|c|c|}
\hline \multirow{2}{*}{$\begin{array}{l}\text { Single or } \\
\text { multiple } \\
\text { pregnancy }\end{array}$} & Single & 28 per 1000 & $\begin{array}{l}26 \text { per } 1000(16 \\
\text { to } 42)\end{array}$ & $\begin{array}{l}\text { RR } 0.92(95 \% \mathrm{Cl} 0.57 \text { to } \\
1.49)\end{array}$ & $\begin{array}{l}2321(2 \\
\text { RCTs) }\end{array}$ & \multirow{2}{*}{$\begin{array}{l}\text { Chi }^{2}=1.28, \mathrm{df}= \\
1(\mathrm{P}=0.26), \mathrm{I}^{2}= \\
22.1 \% \\
\text { (Performed by } \\
\text { overview au- } \\
\text { thors) }\end{array}$} \\
\hline & Multiple & 53 per 1000 & $\begin{array}{l}28 \text { per } 1000(11 \\
\text { to } 67)\end{array}$ & $\begin{array}{l}\text { RR } 0.52(95 \% \mathrm{Cl} 0.21 \text { to } \\
1.25)\end{array}$ & 527 (2 RCTs) & \\
\hline \multirow[t]{2}{*}{$\begin{array}{l}\text { Gestational } \\
\text { age }\end{array}$} & $\begin{array}{l}\text { Less than } 34 \\
\text { weeks at ran- } \\
\text { domisation }\end{array}$ & 56 per 1000 & $\begin{array}{l}39 \text { per } 1000(30 \\
\text { to } 50)\end{array}$ & $\begin{array}{l}\text { RR } 0.69(95 \% \mathrm{Cl} 0.54 \text { to } \\
0.88)\end{array}$ & $\begin{array}{l}5357(5 \\
\text { RCTs) }\end{array}$ & \multirow[t]{2}{*}{$\begin{array}{l}\text { Not applicable } \\
\text { (subgroups not } \\
\text { exclusive) }\end{array}$} \\
\hline & $\begin{array}{l}\text { Less than } 30 \\
\text { weeks at ran- } \\
\text { domisation }\end{array}$ & 56 per 1000 & $\begin{array}{l}48 \text { per } 1000(31 \\
\text { to } 73)\end{array}$ & $\begin{array}{l}\text { RR } 0.86(95 \% \mathrm{Cl} 0.56 \text { to } \\
1.31)\end{array}$ & $\begin{array}{l}1537(2 \\
\text { RCTs) }\end{array}$ & \\
\hline \multirow[t]{2}{*}{$\begin{array}{l}\text { Loading } \\
\text { dose }\end{array}$} & $\begin{array}{l}4 \mathrm{~g} \text { (any or no } \\
\text { maintenance) }\end{array}$ & 43 per 1000 & $\begin{array}{l}34 \text { per } 1000(24 \\
\text { to } 47)\end{array}$ & $\begin{array}{l}\text { RR } 0.79(95 \% \mathrm{Cl} 0.56 \text { to } \\
1.10)\end{array}$ & $\begin{array}{l}3595(4 \\
\text { RCTs) }\end{array}$ & \multirow{2}{*}{$\begin{array}{l}\text { Chi }^{2}=1.33, \mathrm{df}= \\
1(\mathrm{P}=0.25), \mathrm{I}^{2}= \\
24.6 \% \\
\text { (Performed by } \\
\text { overview au- } \\
\text { thors) }\end{array}$} \\
\hline & $\begin{array}{l}6 \mathrm{~g} \text { (any or no } \\
\text { maintenance) }\end{array}$ & 59 per 1000 & $\begin{array}{l}35 \text { per } 1000(24 \\
\text { to } 50)\end{array}$ & $\begin{array}{l}\mathrm{RR} 0.59(95 \% \mathrm{Cl} 0.40 \text { to } \\
0.85)\end{array}$ & 2444 (1 RCT) & \\
\hline \multirow[t]{2}{*}{$\begin{array}{l}\text { Mainte- } \\
\text { nance dose }\end{array}$} & $\begin{array}{l}\text { No maintenance } \\
\text { (any loading) }\end{array}$ & 82 per 1000 & $\begin{array}{l}113 \text { per } 1000 \\
(15 \text { to } 879)\end{array}$ & $\begin{array}{l}\text { RR } 1.37(95 \% \mathrm{Cl} 0.18 \text { to } \\
10.70)\end{array}$ & 747 (2 RCTs) & \multirow{2}{*}{$\begin{array}{l}\text { Chi }^{2}=0.44, \mathrm{df}= \\
1(\mathrm{P}=0.51), \mathrm{I}^{2}= \\
0 \% \\
\text { (Performed by } \\
\text { overview au- } \\
\text { thors) }\end{array}$} \\
\hline & $\begin{array}{l}\text { Any maintenance } \\
\text { (any loading) }\end{array}$ & 45 per 1000 & $\begin{array}{l}31 \text { per } 1000(23 \\
\text { to } 41)\end{array}$ & $\begin{array}{l}\mathrm{RR} 0.68(95 \% \mathrm{Cl} \\
0.51 \text { to } 0.91)\end{array}$ & $\begin{array}{l}5292(3 \\
\text { RCTs) }\end{array}$ & \\
\hline \multirow[t]{3}{*}{$\begin{array}{l}\text { Loading } \\
\text { and mainte- } \\
\text { nance dose }\end{array}$} & $\begin{array}{l}\text { Loading dose ( } 4 \\
\text { g) and no mainte- } \\
\text { nance }\end{array}$ & 82 per 1000 & $\begin{array}{l}113 \text { per } 1000 \\
\text { (15 to } 879)\end{array}$ & $\begin{array}{l}\text { average RR } 1.37 \text { (0.18, } \\
\text { 10.70) }\end{array}$ & 747 (2 RCTs) & \multirow{3}{*}{$\begin{array}{l}\text { Chi }^{2}=2.94, \mathrm{df}= \\
3(\mathrm{P}=0.40), \mathrm{I}^{2}= \\
0 \% \\
\text { (Performed by } \\
\text { overview au- } \\
\text { thors) }\end{array}$} \\
\hline & $\begin{array}{l}\text { Loading dose } \\
(4 \mathrm{~g}) \text { and low- } \\
\text { er-dose mainte- } \\
\text { nance }(1 \mathrm{~g} / \text { hour })\end{array}$ & 33 per 1000 & $\begin{array}{l}27 \text { per } 1000(18 \\
\text { to } 41)\end{array}$ & $\begin{array}{l}\text { average RR } 0.81(95 \% \mathrm{Cl} \\
0.54 \text { to } 1.23)\end{array}$ & $\begin{array}{l}2848(2 \\
\text { RCTs })\end{array}$ & \\
\hline & $\begin{array}{l}\text { Loading dose } \\
(4 \mathrm{~g}) \text { and high- } \\
\text { er-dose mainte- }\end{array}$ & 59 per 1000 & $\begin{array}{l}8 \text { per } 1000 \text { ( } 1 \text { to } \\
148)\end{array}$ & $\begin{array}{l}\text { RR } 0.13(95 \% \mathrm{Cl} 0.01 \text { to } \\
2.51)\end{array}$ & 106 (1 RCT) & \\
\hline
\end{tabular}




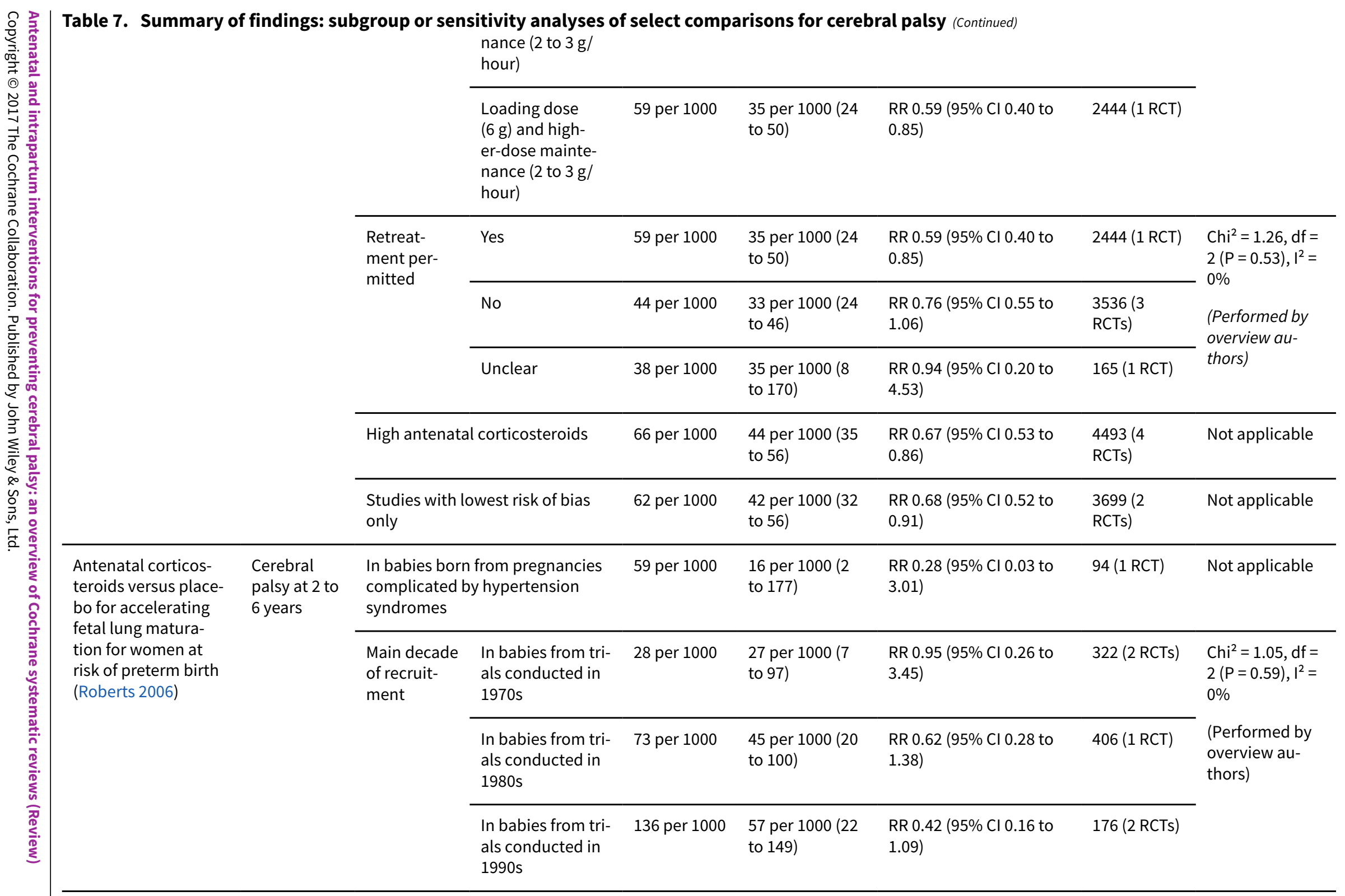




\begin{tabular}{|c|c|c|c|c|c|c|c|}
\hline Intervention and comparison & Outcome & $\begin{array}{l}\text { Assumed risk } \\
\text { with com- } \\
\text { parator }\end{array}$ & $\begin{array}{l}\text { Corresponding } \\
\text { risk with inter- } \\
\text { vention }\end{array}$ & $\begin{array}{l}\text { Relative effect } \\
(95 \% \mathrm{Cl})\end{array}$ & $\begin{array}{l}\text { Number of } \\
\text { participants } \\
\text { (trials) }\end{array}$ & $\begin{array}{l}\text { Quality of } \\
\text { the evidence } \\
\text { (GRADE) }\end{array}$ & Comments \\
\hline \multicolumn{8}{|c|}{ Interventions prior to preterm birth for fetalmaturation or neuroprotection } \\
\hline $\begin{array}{l}\text { Magnesium sulphate versus placebo } \\
\text { for women at risk of preterm birth for } \\
\text { neuroprotection of the fetus (Doyle } \\
\text { 2009) }\end{array}$ & $\begin{array}{l}\text { Death or cerebral pal- } \\
\text { sy between } 18 \text { months } \\
\text { and } 2 \text { years (as above } \\
\text { under cerebral palsy) }\end{array}$ & $\begin{array}{l}188 \text { per } 1000 \\
(583 / 3093)\end{array}$ & $\begin{array}{l}177 \text { per } 1000 \\
\text { (147 to } 211)\end{array}$ & $\begin{array}{l}\text { Average RR } 0.94 \\
(95 \% \mathrm{Cl} 0.78 \text { to } \\
1.12)\end{array}$ & 6145 (5 RCTs) & $\mathrm{HIGH}$ & $\begin{array}{l}\text { not down- } \\
\text { graded }\end{array}$ \\
\hline
\end{tabular}

Table 9. Summary of findings: all comparisons measuring severity of cerebral palsy

\begin{tabular}{|c|c|c|c|c|c|c|c|}
\hline $\begin{array}{l}\text { Intervention } \\
\text { and compari- } \\
\text { son }\end{array}$ & Outcome & $\begin{array}{l}\text { Assumed risk } \\
\text { with com- } \\
\text { parator }\end{array}$ & $\begin{array}{l}\text { Correspond- } \\
\text { ing risk with } \\
\text { intervention }\end{array}$ & $\begin{array}{l}\text { Relative ef- } \\
\text { fect }(95 \% \mathrm{CI})\end{array}$ & $\begin{array}{l}\text { Number of } \\
\text { participants } \\
\text { (trials) }\end{array}$ & $\begin{array}{l}\text { Quality of } \\
\text { the evidence } \\
\text { (GRADE) }\end{array}$ & Comments \\
\hline
\end{tabular}

Interventions for the treatment of pre-eclampsia

\begin{tabular}{|c|c|c|c|c|c|c|c|}
\hline $\begin{array}{l}\text { Magnesium } \\
\text { sulphate ver- } \\
\text { sus placebo } \\
\text { for women } \\
\text { with pre- } \\
\text { eclampsia } \\
\text { (Duley 2010) }\end{array}$ & $\begin{array}{l}\text { Severe cerebral palsy at } 18 \text { months (definition: } \\
\text { not walking or unlikely to walk unaided by } 24 \\
\text { months) } \\
\text { (definition taken from RCT manuscript as not } \\
\text { detailed in review) }\end{array}$ & $\begin{array}{l}6 \text { per } 1000 \\
(9 / 1464)\end{array}$ & $\begin{array}{l}2 \text { per } 1000(1 \\
\text { to } 8)\end{array}$ & $\begin{array}{l}\text { RR } 0.34(95 \% \\
\mathrm{Cl} 0.09 \text { to } \\
1.26)\end{array}$ & $2895(1 \mathrm{RCT})$ & LOW & $\begin{array}{l}\text { study limita- } \\
\text { tions (-1): } 1 \text { RCT } \\
\text { with unclear } \\
\text { risk of attrition } \\
\text { bias for this } \\
\text { outcome ( } 2895 \\
\text { of } 6922 \text { children } \\
\text { in original RCT } \\
\text { included) } \\
\text { imprecision } \\
(-1) \text { : wide confi- } \\
\text { dence intervals } \\
\text { crossing line of } \\
\text { no effect }\end{array}$ \\
\hline \multicolumn{8}{|c|}{ Interventions prior to preterm birth for fetalmaturation or neuroprotection } \\
\hline $\begin{array}{l}\text { Magnesium } \\
\text { sulphate } \\
\text { (neuropro- } \\
\text { tective in- }\end{array}$ & $\begin{array}{l}\text { Mild cerebral palsy at } 2 \text { years } \\
\text { - } 1 \text { RCT: definition: walking at } 2 \text { years; assessed } \\
\text { by developmental paediatrician at } 2 \text { years }\end{array}$ & $\begin{array}{l}33 \text { per } 1000 \\
(74 / 2218)\end{array}$ & $\begin{array}{l}25 \text { per } 1000 \\
\text { (17 to } 35)\end{array}$ & $\begin{array}{l}\text { RR } 0.74(95 \% \\
\mathrm{Cl} 0.52 \text { to } \\
1.04)\end{array}$ & 4387 (3 RCTs) & MODERATE & $\begin{array}{l}\text { imprecision } \\
(-1): \text { wide confi- } \\
\text { dence intervals }\end{array}$ \\
\hline
\end{tabular}




\begin{tabular}{|c|c|c|c|c|c|c|c|}
\hline \multirow[t]{4}{*}{$\begin{array}{l}\text { tent) versus } \\
\text { placebo for } \\
\text { women at risk } \\
\text { of preterm } \\
\text { birth for neu- } \\
\text { roprotection } \\
\text { of the fetus } \\
\text { (Doyle 2009) }\end{array}$} & $\begin{array}{l}1 \text { RCT: definition: Gross Motor Function Clas- } \\
\text { sification System of level } 1 \text {; assessed by pae- } \\
\text { diatrician or paediatric neurologist at } 2 \text { years } \\
\text { - } 1 \text { RCT: definition not clear; paediatricians } \\
\text { evaluated motor function at } 2 \text { years; if exami- } \\
\text { nation was not possible, parent telephone in- } \\
\text { terview was used }\end{array}$ & & & & & & $\begin{array}{l}\text { crossing line of } \\
\text { no effect }\end{array}$ \\
\hline & $\begin{array}{l}\text { Moderate cerebral palsy at } 2 \text { years } \\
\text { - } 1 \text { RCT: definition: not walking at } 2 \text { years but } \\
\text { likely to do so; assessed by developmental } \\
\text { paediatrician at } 2 \text { years } \\
\text { - } 1 \text { RCT: definition not clear; paediatricians } \\
\text { evaluated motor function at } 2 \text { years; if exami- } \\
\text { nation was not possible, parent telephone in- } \\
\text { terview was used }\end{array}$ & $\begin{array}{l}22 \text { per } 1000 \\
(21 / 962)\end{array}$ & $\begin{array}{l}14 \text { per } 1000(7 \\
\text { to } 28)\end{array}$ & $\begin{array}{l}\text { RR } 0.66(95 \% \\
\mathrm{Cl} 0.34 \text { to } \\
1.28)\end{array}$ & 1943 (2 RCTs) & MODERATE & $\begin{array}{l}\text { imprecision } \\
(-1) \text { : wide confi- } \\
\text { dence intervals } \\
\text { crossing line of } \\
\text { no effect }\end{array}$ \\
\hline & $\begin{array}{l}\text { Moderate to severe cerebral palsy at } 2 \text { years } \\
\text { - } 1 \text { RCT: definition: not walking at } 2 \text { years but } \\
\text { likely to do so (moderate); not likely to walk } \\
\text { (severe); assessed by developmental paedia- } \\
\text { trician at } 2 \text { years } \\
\text { - } 1 \text { RCT: definition: Gross Motor Function Clas- } \\
\text { sification System level of } 2 \text { or } 3 \text { (moderate), } \\
\text { or level } 4 \text { or } 5 \text { (severe); assessed by paediatri- } \\
\text { cian or paediatric neurologist at } 2 \text { years } \\
\text { - } 1 \text { RCT: definition not clear; paediatricians } \\
\text { evaluated motor function at } 2 \text { years; if exami- } \\
\text { nation was not possible, parent telephone in- } \\
\text { terview was used }\end{array}$ & $\begin{array}{l}32 \text { per } 1000 \\
(72 / 2218)\end{array}$ & $\begin{array}{l}21 \text { per } 1000 \\
(14 \text { to } 30)\end{array}$ & $\begin{array}{l}\text { RR } 0.64(95 \% \\
\mathrm{Cl} 0.44 \text { to } \\
0.92)\end{array}$ & 4387 (3 RCTs) & $\mathrm{HIGH}$ & $\begin{array}{l}\text { not downgrad- } \\
\text { ed }\end{array}$ \\
\hline & $\begin{array}{l}\text { Severe cerebral palsy at } 2 \text { years } \\
\text { - } 1 \text { RCT: definition: not likely to walk; assessed } \\
\text { by developmental paediatrician at } 2 \text { years } \\
\text { - } 1 \text { RCT: definition not clear; paediatricians } \\
\text { evaluated motor function a } 2 \text { years; if exami- } \\
\text { nation was not possible, parent telephone in- } \\
\text { terview was used }\end{array}$ & $\begin{array}{l}14 \text { per } 1000 \\
(13 / 962)\end{array}$ & $\begin{array}{l}11 \text { per } 1000(5 \\
\text { to } 25)\end{array}$ & $\begin{array}{l}\text { RR } 0.82(95 \% \\
\mathrm{Cl} 0.37 \text { to } \\
1.82)\end{array}$ & 1943 (2 RCTs) & MODERATE & $\begin{array}{l}\text { imprecision } \\
(-1) \text { : wide confi- } \\
\text { dence intervals } \\
\text { crossing line of } \\
\text { no effect }\end{array}$ \\
\hline
\end{tabular}


Table 10. Summary of findings: all comparisons measuring other composite outcomes that include cerebral palsy as a component

\begin{tabular}{|c|c|c|c|c|c|c|c|}
\hline $\begin{array}{l}\text { Intervention } \\
\text { and compari- } \\
\text { son }\end{array}$ & Outcome & $\begin{array}{l}\text { Assumed risk } \\
\text { with com- } \\
\text { parator }\end{array}$ & $\begin{array}{l}\text { Correspond- } \\
\text { ing risk with } \\
\text { intervention }\end{array}$ & $\begin{array}{l}\text { Relative ef- } \\
\text { fect }(95 \% \mathrm{CI})\end{array}$ & $\begin{array}{l}\text { Number of } \\
\text { participants } \\
\text { (trials) }\end{array}$ & $\begin{array}{l}\text { Quality of } \\
\text { the evidence } \\
\text { (GRADE) }\end{array}$ & Comments \\
\hline
\end{tabular}

son

parator

intervention

(GRADE)

Interventions for the treatment of pre-eclampsia

Magnesium Neurosensory disability at 18 months (defisulphate ver- nition: functional blindness (binocular visu-

sus placebo al acuity $<6 / 60$ ), deafness (severe enough

for women to need a hearing aid), severe cerebral pal-

8 per $1000(4$

RR 0.77 (95\%

$3283(1 \mathrm{RCT})$

LOW

$1.58)$

with pre- $\quad$ sy, or DQ $<2$ SD below the mean)

eclampsia

(Duley 2010)

$(17 / 1648$

to 16$)$

tudy limitations

$(-1): 1$ RCT with un-

clear risk of attri-

tion bias for this

outcome (3283 of

6922 children in

original RCT includ-

ed)

imprecision (-1):

wide confidence

intervals crossing

line of no effect

Death or neurosensory disability at 18

months (definition as above for 'neursenso-

141 per 1000

150 per 1000

RR 1.06 (95\%

$3283(1 \mathrm{RCT})$

LOW

study limitations

ry disability at 18 months')

(233/1648)

Clo.90 to

$(-1): 1$ RCT with un

clear risk of attri-

tion bias for this

outcome (3283 of

6922 children in

original RCT includ-

ed)

imprecision (-1)

wide confidence

intervals crossing

line of no effect

Interventions for the prevention of preterm birth

Magnesium

sulphate ver-

sus other to-

Serious infant outcome (definition: total

perinatal and infant mortality; IVH $3 / 4$ or

PVL; cerebral palsy at 18 months; assess-

59 per 1000

145 per 1000

RR $2.47(95 \%$

$106(1 \mathrm{RCT})$

VERY LOW

study limitations

(41 to 518$) \quad \mathrm{Cl} 0.69$ to

8.81 )

$(-1): 1$ RCT with un

clear risk of selec-

tion, attrition, and

for preventing sy')

preterm birth
in threat-

ened preterm outcome)

righ bias and

mance bias 







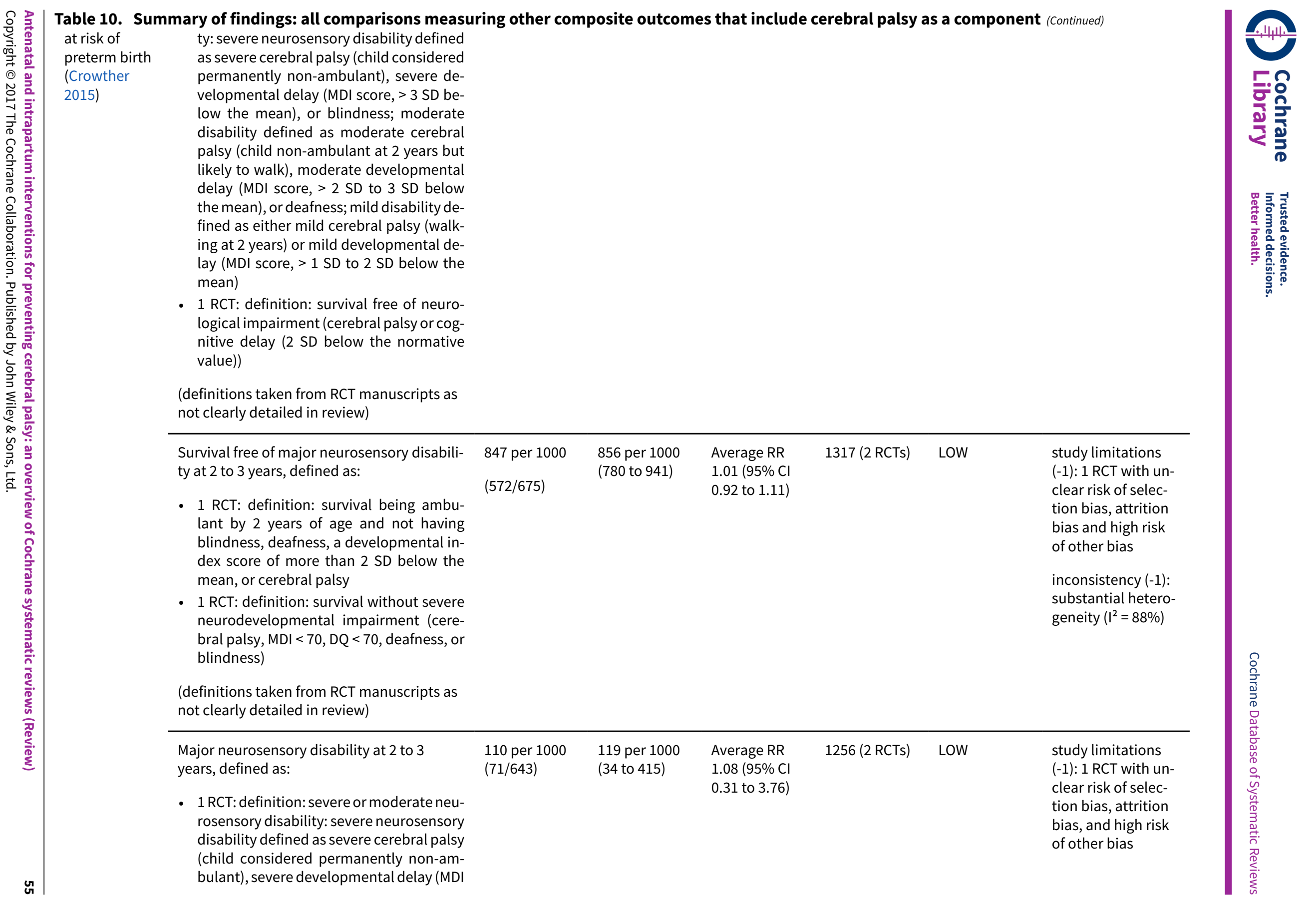


able 10. Summary of findings: all comparisons measuring other composite outcomes that include cerebral palsy as a component (Continued)

score $>3$ SD below the mean), or blind-

ness; moderate disability defined as mod-

erate cerebral palsy (child non-ambulant

at 2 years but likely to walk), moderate de-

velopmental delay (MDI score $>2$ SD to 3

$\mathrm{SD}$ below the mean), or deafness

- 1 RCT: definition: severe neurodevelop-

mental impairment (cerebral palsy, $\mathrm{MDI}<$

$70, \mathrm{DQ}<70$, deafness, or blindness)

(definitions taken from RCT manuscripts as not clearly detailed in review)

Disability at 2 years, defined as:

- 1 RCT: definition: severe, moderate, or mild neurosensory disability: severe neurosensory disability defined as severe cerebral palsy (child considered permanently non-ambulant), severe developmental delay (MDI score $>3$ SD below the mean), or blindness; moderate disability defined as moderate cerebral palsy (child non-ambulant at 2 years but likely to walk), moderate developmental delay (MDI score $>2$ SD to 3 SD below the mean), or deafness; mild disability was defined as either mild cerebral palsy (walking at 2 years) or mild developmental delay (MDI score $>1$ SD to 2 SD below the mean)

361 per 1000

361 per 1000

354 per 1000

(300 to 419$)$

RR $0.98(95 \%$

999 (1 RCT)

$\mathrm{HIGH}$

not downgraded

1.16)

imprecision $(-1)$ :

wide confidence

intervals crossing

line of no effect

(definition taken from RCT manuscript as

not clearly detailed in review)

Composite serious outcome at 18 months

to 2 years, defined as:

227 per 1000

224 per 1000

(197 to 254)

RR 0.99 (95\%

3164 (2 RCTs)

HIGH

1.12)

- 1 RCT: definition: death or any neurosensory disability: severe, moderate or mild neurosensory disability: severe neurosensory disability defined as severe cerebral palsy (child considered permanently non-ambulant), severe developmental delay (MDI score > 3 SD below the mean), or blindness; moderate disability defined as moderate cerebral pal- 


\begin{tabular}{|c|c|c|c|c|c|c|c|}
\hline su & $\begin{array}{l}\text { sy (child non-ambulant at } 2 \text { years but like- } \\
\text { ly to walk), moderate developmental de- } \\
\text { lay (MDI score > } 2 \text { SD to } 3 \text { SD below the } \\
\text { mean), or deafness; mild disability de- } \\
\text { fined as either mild cerebral palsy (walk- } \\
\text { ing at } 2 \text { years) or mild developmental de- } \\
\text { lay (MDI score > } 1 \text { SD to } 2 \text { SD below the } \\
\text { mean) } \\
1 \text { RCT: definition: death or neurologic im- } \\
\text { pairment (cerebral palsy or cognitive de- } \\
\text { lay (cognitive delay was defined as } 2 \text { SD } \\
\text { below the normative value)) } \\
\text { (definitions taken from RCT manuscripts as } \\
\text { not clearly detailed in review) }\end{array}$ & & & & & & \\
\hline \multicolumn{8}{|c|}{ Interventions for the management of preterm fetalcompromise } \\
\hline \multirow[t]{2}{*}{$\begin{array}{l}\text { Immediate } \\
\text { versus de- } \\
\text { ferred de- } \\
\text { livery of the } \\
\text { preterm ba- } \\
\text { by with sus- } \\
\text { pected fetal } \\
\text { compromise } \\
\text { (Stock 2016) }\end{array}$} & $\begin{array}{l}\text { Death or disability at or after } 2 \text { years (defi- } \\
\text { nition: cerebral palsy, little or no vision, re- } \\
\text { quirement for hearing aid, or Griffiths DQ of } \\
70 \text { or less) }\end{array}$ & $\begin{array}{l}155 \text { per } 1000 \\
(44 / 283)\end{array}$ & $\begin{array}{l}190 \text { per } 1000 \\
(132 \text { to } 272)\end{array}$ & $\begin{array}{l}\text { RR } 1.22(95 \% \\
\mathrm{Cl} 0.85 \text { to } \\
1.75)\end{array}$ & 573 (1 RCT) & LOW & $\begin{array}{l}\text { study limitations } \\
(-1): 1 \text { RCT at high } \\
\text { risk of performance } \\
\text { bias and other bias } \\
\text { (did not account } \\
\text { for non-indepen- } \\
\text { dence of data for } \\
\text { twin pregnancies) } \\
\text { imprecision (-1): } \\
\text { wide intervals } \\
\text { crossing line of no } \\
\text { effect }\end{array}$ \\
\hline & $\begin{array}{l}\text { Neurodevelopmental impairment at or af- } \\
\text { ter } 2 \text { years (definition: cerebral palsy, little } \\
\text { or no vision, requirement for hearing aid, or } \\
\text { Griffiths DQ of } 70 \text { or less) }\end{array}$ & $\begin{array}{l}48 \text { per } 1000 \\
(12 / 251)\end{array}$ & $\begin{array}{l}82 \text { per } 1000 \\
\text { (41 to } 163 \text { ) }\end{array}$ & $\begin{array}{l}\text { RR } 1.72(95 \% \\
\mathrm{Cl} 0.86 \text { to } \\
3.41)\end{array}$ & 507 (1 RCT) & LOW & $\begin{array}{l}\text { study limitations } \\
\text { (-1): } 1 \text { RCT at high } \\
\text { risk of performance } \\
\text { bias and other bias } \\
\text { (did not account } \\
\text { for non-indepen- } \\
\text { dence of data for } \\
\text { twin pregnancies) } \\
\text { imprecision (-1): } \\
\text { wide intervals } \\
\text { crossing line of no } \\
\text { effect }\end{array}$ \\
\hline
\end{tabular}




\begin{tabular}{|c|c|c|c|c|c|c|c|}
\hline & $\begin{array}{l}\text { Death or severe disability at } 6 \text { to } 13 \text { years } \\
\text { (definition: classified severe blindness, se- } \\
\text { vere deafness, cerebral palsy, or Kaufman } \\
\text { Mental Processing Component < } 70 \text { points) } \\
\text { (definition taken from RCT manuscript as } \\
\text { not detailed in review) }\end{array}$ & $\begin{array}{l}168 \text { per } 1000 \\
(25 / 149)\end{array}$ & $\begin{array}{l}138 \text { per } 1000 \\
(81 \text { to } 235)\end{array}$ & $\begin{array}{l}\text { RR } 0.82 \text { (95\% } \\
\text { Cl } 0.48 \text { to } \\
1.40)\end{array}$ & $302(1 \mathrm{RCT})$ & LOW & $\begin{array}{l}\text { study limitations } \\
(-1): 1 \text { RCT at high } \\
\text { risk of perfor- } \\
\text { mance, attrition } \\
\text { and other bias } \\
\text { imprecision }(-1) \text { : } \\
\text { wide intervals } \\
\text { crossing line of no } \\
\text { effect }\end{array}$ \\
\hline \multicolumn{8}{|c|}{$\begin{array}{l}\text { Abbreviations: Cl: confidence intervals; DQ: developmental quotient; IQ: intelligence quotient; IVH: intraventricular haemorrhage; MDI: mental development index; PVL: } \\
\text { periventricular leukomalacia; RCT: randomised controlled trial; RR: risk ratio; SD: standard deviation }\end{array}$} \\
\hline $\begin{array}{l}\text { Intervention and } \\
\text { comparison }\end{array}$ & Outcome & $\begin{array}{l}\text { Assumed risk } \\
\text { with com- } \\
\text { parator }\end{array}$ & $\begin{array}{l}\text { Correspond- } \\
\text { ing risk with } \\
\text { intervention }\end{array}$ & $\begin{array}{l}\text { Relative ef- } \\
\text { fect }(95 \% \mathrm{Cl})\end{array}$ & $\begin{array}{l}\text { Number of } \\
\text { participants } \\
\text { (trials) }\end{array}$ & $\begin{array}{l}\text { Quality of } \\
\text { the evidence } \\
\text { (GRADE) }\end{array}$ & Comments \\
\hline \multicolumn{8}{|c|}{ Interventions for the prevention of preterm birth } \\
\hline \multicolumn{8}{|c|}{ Interventions prior to preterm birth for fetal maturation or neuroprotection } \\
\hline $\begin{array}{l}\text { Phenobarbital ver- } \\
\text { sus control prior to } \\
\text { preterm birth for } \\
\text { preventing neona- } \\
\text { tal periventricu- } \\
\text { lar haemorrhage } \\
\text { (Crowther 2010a) }\end{array}$ & $\begin{array}{l}\text { Other neuromotor impairment at } 3 \\
\text { years (definition: tonal abnormali- } \\
\text { ties with no delay in ambulation or } \\
\text { other motor milestones) } \\
\text { (definition taken from RCT manu- } \\
\text { script as not detailed in review) }\end{array}$ & $\begin{array}{l}73 \text { per } 1000 \\
(4 / 55)\end{array}$ & $\begin{array}{l}49 \text { per } 1000(9 \\
\text { to 254) }\end{array}$ & $\begin{array}{l}\text { RR } 0.67 \text { (95\% } \\
\text { Cl } 0.13 \text { to } \\
3.49)\end{array}$ & $96(1 \mathrm{RCT})$ & VERY LOW & $\begin{array}{l}\text { study limitations }(-2) \text { : } \\
1 \text { RCT with high risk } \\
\text { of selection bias, bias } \\
\text { due to lack of blind- } \\
\text { ing, and attrition bias } \\
\text { imprecision (-2): } \\
\text { wide confidence in- }\end{array}$ \\
\hline
\end{tabular}




\begin{tabular}{l|llllll} 
Table 11. Summary of findings: all comparisons measuring motor dysfunction (Continued) & & \\
tervals crossing line \\
of no effect; 1 small \\
RCT with few events
\end{tabular}

Abbreviations: $\mathrm{Cl}$ : confidence intervals; RCT: randomised controlled trial; RR: risk ratio 


\section{A P PEN DICES}

\section{Appendix 1. Ongoing reviews}

\section{Protocol citation}

Amorim 2011

\section{Overview of pre-specified outcomes in protocol}

Secondary pre-specified perinatal and neonatal outcomes include:

- Long-term disability: blindness, deafness, seizures, poor growth, neurodevelopmental delay, and cerebral palsy.

Bimbashi A, Duley L, Ndoni E, Dokle A. Amniotomy plus intravenous oxytocin for induction of labour. Cochrane Database of Systematic Reviews 2012, Issue 4.
Primary pre-specified outcomes for the baby include:

- Serious neonatal morbidity or perinatal death (e.g. seizures, birth asphyxia defined by trialists, neonatal encephalopathy, disability in childhood).

Secondary pre-specified outcomes for the baby include:

- Individual components of serious neonatal morbidity or perinatal death, as listed above (perinatal death, total baby death, seizures, birth asphyxia defined by trialists, neonatal encephalopathy, disability in childhood - such as neurodevelopmental delay, blind, deaf, cerebral palsy).
Dodd JM, Grivell RM, O'Brien CM, Dowswell T, Deussen AR. Prenatal administration of progestogens for preventing preterm birth in women with a multiple pregnancy. Cochrane Database of Systematic Reviews 2016, Issue 1.
Primary pre-specified outcomes for the infant include:

- Major neurodevelopmental disability at childhood follow-up.

Secondary pre-specified outcomes for the child include:

- Major sensorineural disability (defined as any of: legal blindness, sensorineural deafness requiring hearing aids, moderate or severe cerebral palsy, developmental delay, or intellectual impairment (defined as developmental quotient or intelligence quotient less than two standard deviations below mean)).

- Cerebral palsy.
Dutta D, Sule M, Ray A. Epidural therapy for the treatment of severe pre-eclampsia in non labouring women. Cochrane Database of Systematic Reviews 2012, Issue 1.
Secondary pre-specified outcome for the child include:

- Long-term growth and development: blindness, deafness, seizures, poor growth, neurodevelopmental delay, and cerebral palsy.
Eke AC, Ezebialu IU, Eleje GU. Hypnosis for preventing preterm labour. Cochrane Database of Systematic Reviews 2012, Issue 11.
Secondary pre-specified outcomes for the child include:

- Major sensorineural disability (defined as any of: legal blindness, sensorineural deafness requiring hearing aids, moderate or severe cerebral palsy, developmental delay, or intellectual impairment (defined as developmental quotient or intelligence quotient less than two standard deviations below mean)).

- Cerebral palsy.
Haruna M, Matsuzaki M, Ota E, Shiraishi M, Hanada N, Mori R. Guided imagery for treating hypertension in pregnancy. Cochrane Database of Systematic Reviews 2014, Issue 10.
Secondary pre-specified outcomes for the neonate include:

- Long-term growth and development: blindness, deafness, seizures, poor growth, neurodevelopmental delay, and cerebral palsy.
Hobson SR, Mockler JC, Lim R, Alers NO, Miller $\mathrm{SL}$, Wallace EM. Melatonin for preventing preeclampsia. Cochrane Database of Systematic Reviews 2015, Issue 5.
Secondary pre-specified outcomes for the child include:

- Long-term growth and development: blindness, deafness, seizures, poor growth, neurodevelopmental delay, and cerebral palsy. 
(Continued)

Hobson SR, Mockler JC, Lim R, Alers NO, Miller Secondary pre-specified outcomes for the child include: $\mathrm{SL}$, Wallace EM. Melatonin for treating preeclampsia. Cochrane Database of Systematic Reviews 2016, Issue 3.

- Long-term growth and development: blindness, deafness, seizures, poor growth, neurodevelopmental delay, and cerebral palsy.

Martis R, Emilia O, Nurdiati DS. Intermittent auscultation (IA) of fetal heart rate in labour for fetal well-being. Cochrane Database of Systematic Reviews 2010, Issue 9.
Secondary pre-specified outcomes for the baby include:

- Cerebral palsy.

\section{Appendix 2. Reviews awaiting further classification}

\section{Review citation \\ Overview of pre-specified out- comes in review with no out- come data \\ Main conclusion(s) of review}

\section{Primary outcomes include:}

- Neurodevelopmental disability at 18 months or more postnatal age, defined as neurological abnormality, including: cerebral palsy on clinical examination; developmental delay more than two standard deviations below population mean on any standard test of development; blindness (visual acuity less than $6 / 60$ ); or deafness (any hearing impairment requiring amplification) at any time after term corrected age.
No included trials.

"We identified no randomised trials that evaluated the effect of intra-amniotic instillation of surfactant for women at risk of preterm birth. Evidence from animal and observational human studies suggest that intra-amniotic surfactant administration is potentially safe, feasible and effective. Well designed trials of intra-amniotic instillation of surfactant for women at risk of preterm birth are needed."
Bain E, Heatley E, Hsu $\mathrm{K}$, Crowther CA. Relaxin for preventing preterm birth. Cochrane Database of Systematic Reviews 2013, Issue 8 .

\section{Secondary outcomes for the in-} fant/child include:

- Cerebral palsy.
"There is limited randomised controlled trial evidence available on the effect of relaxin during pregnancy for preventing preterm birth for women in preterm labour. Evidence from one quasi-randomised trial suggested a reduction in birth within seven days of treatment for women receiving relaxin, compared with women in a control group, however this trial was at a high risk of bias and included only 30 women. Thus, there is insufficient evidence to support or refute the use of relaxin in women in preterm labour for preventing preterm birth."

No included trials.

"Although strong evidence supports the use of antenatal magnesium sulphate for neuroprotection of the fetus prior to very preterm birth, no trials comparing different treatment regimens have been completed. Research should be directed towards comparisons of different dosages and other variations in regimens, evaluating both maternal and infant outcomes."
Database of Systematic

Reviews 2012, Issue 2.
Primary outcomes for the infant/child include:

- Cerebral palsy (abnormality of tone with motor dysfunction, or as defined by trialists).

- Death or cerebral palsy (as they are competing outcomes, this combined outcome is often considered the 
(Continued)

most clinically relevant for assessing neuroprotection).

Secondary outcomes for the infant/child include:

- Cerebral palsy (mild, moderate or severe, evaluated separately, as defined by trialists).

- Major neurologic disability (including: moderate or severe cerebral palsy (as defined by trialists)).
Bain E, Pierides KL, Clifton VL, Hodyl NA, Stark MJ, Crowther CA, et al. Interventions for managing asthma in pregnancy. Cochrane Database of Systematic Reviews 2014, Issue 10.
Secondary outcomes for the infant, child, and for the child as an adult include:

- Any neurodevelopmental disability (blindness, deafness, moderate or severe cerebral palsy (however defined by authors), or development delay or intellectual impairment (defined as developmental quotient or intelligence quotient more than two standard deviations below population mean)).

- Cerebral palsy (however defined by authors).
"Based on eight included trials, of moderate quality overall, no firm conclusions about optimal interventions for managing asthma in pregnancy can be made. Five trials assessing pharmacological interventions did not provide clear evidence of benefits or harms to support or refute current practice. While inhaled magnesium sulphate for acute asthma was shown to reduce exacerbations, this was in one small trial of unclear quality, and thus, this finding should be interpreted with caution. Three trials assessing non-pharmacological interventions provided some support for the use of such strategies, however, were not powered to detect differences in important maternal and infant outcomes. While a FENO-based algorithm reduced exacerbations, the effects on perinatal outcomes were less certain, and thus, widespread implementation is not yet appropriate. Similarly, though positive effects on asthma control were shown with PMR and pharmacist-led management, the evidence to date is insufficient to draw definitive conclusions.

In view of the limited evidence base, further randomised trials are required to determine the most effective and safe interventions for asthma in pregnancy. Future trials must be sufficiently powered, and welldesigned, to allow differences in important outcomes for mothers and babies to be detected. The impact on health services requires evaluation. Any further trials assessing pharmacological interventions should assess novel agents or those used in current practice. Encouragingly, at least five trials have been identified as planned or underway."

\section{No included trials.}

"There is no robust evidence from randomised trials to indicate whether specialised diets or nutritional advice for women with multiple pregnancies do more good than harm. There is a clear need to undertake a randomised controlled trial." pregnancies. Cochrane

Database of Systematic

Reviews 2015, Issue 11.
Secondary outcomes for the child include:

- Cerebral palsy.
"Antibiotic treatment can eradicate bacterial vaginosis in pregnancy. The overall risk of PTB was not significantly reduced. This review provides little evidence that screening and treating all pregnant women with bacterial vaginosis will prevent PTB and its consequences. When screening criteria were broadened to include women with abnormal flora there was a $47 \%$ reduction in preterm birth, however, this is limited to two included studies."
Brocklehurst $\mathrm{P}$, Gordon

A, Heatley E, Milan SJ. Antibiotics for treating bacterial vaginosis in pregnancy. Cochrane Database of Systematic Reviews 2013, Issue 1.
Secondary outcomes for the neonate include:

- Cerebral palsy at childhood follow-up.
Brownfoot FC, Gagliardi DI, Bain E, Middleton $P$, Crowther CA. Different corticosteroids and regimens for accelerating
Primary outcomes for the child include:

- Neurodevelopmental disability at follow-up (blindness,
"It remains unclear whether one corticosteroid (or one particular regimen) has advantages over another. Dexamethasone may have some benefits compared with betamethasone, such as less IVH, and a shorter length of stay in the NICU. The intramuscular route may have advantages over the oral route for dexamethasone, as identified in one 
(Continued)

fetal lung maturation for women at risk of preterm birth. Cochrane Database of Systematic Reviews 2013, Issue 8. deafness, moderate or severe cerebral palsy (however defined by authors), or developmental delay or intellectual impairment (defined as developmental quotient or intelligence quotient less than two standard deviations below population mean) or variously defined).

Primary outcomes for the child as an adult include:

- Neurodevelopmental disability at follow-up (blindness, deafness, moderate or severe cerebral palsy (however defined by authors), or developmental delay or intellectual impairment (defined as developmental quotient or intelligence quotient less than two standard deviations below population mean), or variously defined.

Secondary outcomes for the child include:

- Cerebral palsy (however defined by authors);

\section{Chawanpaiboon}

S, Laopaiboon M, Lumbiganon $\mathrm{P}$, Sangkomkamhang US, Dowswell T. Terbutaline pump maintenance therapy after threatened preterm labour for reducing adverse neonatal outcomes. Cochrane Database of Systematic Reviews 2014, Issue 3.
Secondary outcomes for the neonate include:

- Neurological sequelae (general intelligence, hearing, vision, cerebral palsy, and disability). small trial. Apart from the suggestion that 12-hour dosing may be as effective as 24-hour dosing of betamethasone, based on one small trial, we were unable to make few other conclusions about optimal antenatal corticosteroid regimens. No long-term results were available, except for a small subgroup of 18-month old children in one trial. Trials comparing the commonly used corticosteroids are most urgently needed, as are trials of dosages and other variations in treatment regimens."
"We found no evidence that terbutaline pump maintenance therapy decreased adverse neonatal outcomes. Taken together with the lack of evidence of benefit, its substantial expense, and the lack of information on the safety of the therapy, the evidence does not support its use in the management of arrested preterm labour. Future use should only be in the context of well-conducted, adequately powered randomised controlled trials."

\section{Cluett ER, Burns E.} Immersion in water in labour and birth. Cochrane Database of Systematic Reviews 2009, Issue 2.

\section{Primary outcomes for the} neonate include:

- Neurological pathology, e.g. seizures, cerebral palsy.
"Evidence suggests that water immersion during the first stage of labour reduces the use of epidural or spinal analgesia and duration of the first stage of labour. There is limited information for other outcomes related to water use during the first and second stages of labour, due to intervention and outcome variability. There is no evidence of increased adverse effects to the fetus, neonate or woman from labouring in water or a water birth. However, the studies are very variable and considerable heterogeneity was detected for some outcomes. Further research is needed."

"Contrary to continued use in some clinical areas, we found no evidence of benefit for the use of the admission cardiotocograph (CTG) for low-risk women on admission in labour.
Devane D, Lalor JG Daly S, McGuire W, Smith V. Cardiotocography versus intermit-
Primary outcomes for the infant include: 
(Continued)

tent auscultation of fetal heart on admission to labour ward for assessment of fetal wellbeing. Cochrane Database of Systematic Reviews 2012, Issue 2.
- Severe neurodevelopmental disability assessed at greater than, or equal to, 12 months of age. We have defined severe neurodevelopmental disability as any one or a combination of the following: non-ambulant cerebral palsy, developmental delay (developmental quotient less than 70), auditory, and visual impairment. Development should have been assessed by means of a previously validated tool, such as Bayley Scales of Infant Development (Psychomotor Developmental Index and Mental Developmental Index).
Dickinson H, Bain E, Wilkinson D, Middleton P, Crowther CA, Walker DW. Creatine for women in pregnancy for neuroprotection of the fetus. Cochrane Database of Systematic Reviews 2014, Issue 12.
Primary outcomes for the infant and child include:

- Death or any neurosensory disability (at latest time reported); this combined outcome recognises the potential for competing risks of death or survival with neurological problems.

- Neurosensory disability (any of cerebral palsy, blindness, deafness, developmental delay or intellectual impairment; at latest time reported).

Secondary outcomes for the infant/child include:

- Cerebral palsy (any, and graded as severe: including children who are non-ambulant and are likely to remain so; moderate: including those children who have substantial limitation of movement; mild: including those children walking with little limitation of movement).

- Death or cerebral palsy.

- Major neurosensory disability (defined as any of: moderate or severe cerebral palsy, legal blindness, neurosensory deafness requiring hearing aids, or moderate or severe developmental delay, or intellectual impairment).
We found no evidence of benefit for the use of the admission CTG for low-risk women on admission in labour. Furthermore, the probability is that admission CTG increases the caesarean section rate by approximately $20 \%$. The data lacked power to detect possible important differences in perinatal mortality. However, it is unlikely that any trial, or meta-analysis, will be adequately powered to detect such differences. The findings of this review support recommendations that the admission CTG not be used for women who are low risk on admission in labour. Women should be informed that admission CTG is likely associated with an increase in the incidence of caesarean section without evidence of benefit."

\section{No included trials.}

"As we did not identify any randomised controlled trials for inclusion in this review, we are unable to comment on implications for practice. Although evidence from animal studies has supported a fetal neuroprotective role for creatine when administered to the mother during pregnancy, no trials assessing creatine in pregnant women for fetal neuroprotection have been published to date. If creatine is established as safe for the mother and her fetus, research efforts should first be directed towards randomised trials comparing creatine with either no intervention (ideally using a placebo), or with alternative agents aimed at providing fetal neuroprotection (including magnesium sulphate for the very preterm infant). If appropriate, these trials should then be followed by studies comparing different creatine regimens (dosage and duration of exposure). Such trials should be high quality and adequately powered to evaluate maternal and infant short and longer-term outcomes (including neurodevelopmental disabilities, such as cerebral palsy), and should consider utilisation and costs of health care." 
(Continued)

\section{Dodd JM, Dowswell} T, Crowther CA. Specialised antenatal clinics for women with a multiple pregnancy for improving maternal and infant outcomes. Cochrane Database of Systematic Reviews 2015, Issue 11.
Secondary outcomes for the infant include:

- Disability at childhood follow-up (including deafness, blindness, neurodisability, or cerebral palsy).
"There is currently limited information available from randomised controlled trials to assess the role of 'specialised' antenatal clinics for women with a multiple pregnancy compared with 'standard' antenatal care in improving maternal and infant health outcomes. The value of 'specialised' multiple pregnancy clinics in improving health outcomes for women and their infants requires evaluation in appropriately powered and designed randomised controlled trials."
Drakeley AJ, Roberts D, Alfirevic Z. Cervical stitch (cerclage) for preventing pregnancy loss in women. Cochrane Database of Systematic Reviews 2003, Issue 1.

\section{Neonatal outcomes include:}

- Infant and child development - such as cerebral palsy; mental retardation, hearing and vision as assessed by paediatric follow-up and attainment of developmental milestones (less than one year; less than two years; greater than two years.

\footnotetext{
Duckitt K, Thornton

S, O'Donovan OP, Dowswell T. Nitric oxide donors for treating preterm labour. Cochrane Database of Systematic Reviews 2014, Issue 5.

Primary outcomes for the infant include:

- Long-term neurological development (general intelligence, hearing, vision, cerebral palsy, and disability, (serious infant outcome)).
}

\begin{abstract}
"The use of a cervical stitch should not be offered to women at low or medium risk of mid trimester loss, regardless of cervical length by ultrasound. The role of cervical cerclage for women who have short cervix on ultrasound remains uncertain as the numbers of randomised women are too few to draw firm conclusions. There is no information available as to the effect of cervical cerclage or its alternatives on the family unit and long term outcome."
\end{abstract}

"There is currently insufficient evidence to support the routine administration of nitric oxide donors in the treatment of threatened preterm labour."

\footnotetext{
Duley L, Gülmezoglu AM, Chou D. Magnesium sulphate versus lytic cocktail for eclampsia. Cochrane Database of Systematic Reviews 2010, Issue 9.
}

\section{Secondary outcomes for the child include:}

- Long-term growth and development: blindness, deafness, seizures, poor growth, neurodevelopmental delay, and cerebral palsy.

\begin{abstract}
"Magnesium sulphate, rather than lytic cocktail, for women with eclampsia reduces the risk ratio of maternal death, of further seizures and of serious maternal morbidity (respiratory depression, coma, pneumonia). Magnesium sulphate is the anticonvulsant of choice for women with eclampsia; the use of lytic cocktail should be abandoned."
\end{abstract}

\section{Duley L, Hender- son-Smart DJ, Chou D. Magnesium sulphate versus phenytoin for eclampsia. Cochrane Database of Systematic Reviews 2010, Issue 10.}

Duley L, Henderson-Smart DJ, Meher S. Altered dietary salt for preventing pre-eclampsia, and its complications. Cochrane Database of Systematic Reviews 2005, Issue 4.

\section{Secondary outcomes for the} child include:

- Long-term growth and development: blindness, deafness, seizures, poor growth, neurodevelopmental delay, and cerebral palsy.

\begin{abstract}
"Magnesium sulphate, rather than phenytoin, for women with eclampsia reduces the risk ratio of recurrence of seizures, probably reduces the risk of maternal death, and improves outcome for the baby. Magnesium sulphate is the drug of choice for women with eclampsia. The use of phenytoin should be abandoned."
\end{abstract}

Outcomes for the child include:

- Long-term growth and development: blindness, deafness, seizures, poor growth, neurodevelopmental delay, and cerebral palsy.
"In the absence of evidence that advice to alter salt intake during pregnancy has any beneficial effect for prevention of pre-eclampsia or any other outcome, salt consumption during pregnancy should remain a matter of personal preference." 
(Continued)

Duley L, Henderson-Smart DJ, Meher S, King JF. Antiplatelet agents for preventing pre-eclampsia and its complications. Cochrane Database of Systematic Reviews 2007, Issue 2.
Outcomes for the child include:

- Infant and child development (such as cerebral palsy, cognitive delay, deafness, and blindness).
"Antiplatelet agents, largely low-dose aspirin, have moderate benefits when used for prevention of pre-eclampsia and its consequences. Further information is required to assess which women are most likely to benefit, when treatment is best started, and at what dose."

\section{Duley L, Hender- son-Smart DJ, Walker \\ GJA, Chou D. Magne- sium sulphate versus diazepam for eclamp- sia. Cochrane Database of Systematic Reviews 2010, Issue 12.}

Secondary outcomes for the child include:

- Long-term growth and development: blindness, deafness, seizures, poor growth, neurodevelopmental delay, and cerebral palsy.

\begin{abstract}
"Magnesium sulphate for women with eclampsia reduces the risk ratio of maternal death and of recurrence of seizures, compared with diazepam."
\end{abstract}

Duley L, Matar HE, Almerie MQ, Hall DR. Alternative magnesium sulphate regimens for women with preeclampsia and eclampsia. Cochrane Database of Systematic Reviews 2010, Issue 8.
Secondary outcomes for the baby include:

- Development in childhood: including cerebral palsy and major neurodevelopmental delay.
"Although strong evidence supports the use of magnesium sulphate for prevention and treatment of eclampsia, trials comparing alternative treatment regimens are too small for reliable conclusions."
Duley L, Meher S, Jones L. Drugs for treatment of very high blood pressure during pregnancy. Cochrane Database of Systematic Reviews 2013, Issue 7.
Secondary outcomes for the child include:

- Long-term growth and development: blindness, deafness, seizures, poor growth, neurodevelopmental delay, and cerebral palsy.
"Until better evidence is available, the choice of antihypertensive should depend on the clinician's experience and familiarity with a particular drug; on what is known about adverse effects; and on women's preferences. Exceptions are nimodipine, magnesium sulphate (although this is indicated for women who require an anticonvulsant for prevention or treatment of eclampsia), diazoxide and ketanserin, which are probably best avoided."

\footnotetext{
Duley L, Williams J, Henderson-Smart DJ. Plasma volume expansion for treatment of pre-eclampsia. Cochrane Database of Systematic Reviews 1999, Issue 4.
}

Outcomes for the baby include:

- Measures of infant and child development (such as cerebral palsy).
"There is insufficient evidence for any reliable estimates of the effects of plasma volume expansion for women with pre-eclampsia."
Flenady V, Reinebrant HE, Liley HG, Tambimuttu EG, Papatsonis DNM. Oxytocin receptor antagonists for inhibiting preterm labour. Cochrane Database of Systematic Reviews 2014, Issue 6.

\section{Primary outcomes include:}

- Serious infant outcome (defined as death or chronic lung disease (need for supplemental oxygen at 28 days of life or later), grade three or four intraventricular haemorrhage or periventricular leukomalacia, major neurosensory disability (defined as any of: legal blindness, sensorineural deafness requiring hear-
"This review did not demonstrate superiority of oxytocin receptor antagonists (ORA; largely atosiban) as a tocolytic agent compared with placebo, betamimetics, or calcium channel blockers (CCB; largely nifedipine) in terms of pregnancy prolongation or neonatal outcomes, although ORA was associated with less maternal adverse effects than treatment with the CCB or betamimetics. The finding of an increase in infant deaths, and more births before completion of 28 weeks of gestation in one placebo-controlled study warrants caution. However, the number of women enrolled at very low gestations was small. Due to limitations of small numbers studied and methodological quality, further well-designed randomised controlled trials are needed. Further comparisons of ORA versus CCB (which has a better side-effect profile than betamimetics) are needed. Consideration of further place- 
(Continued)

ing aids, moderate or severe cerebral palsy, or developmental delay or intellectual impairment (defined as developmental quotient (DQ) or intelligence quotient (IQ) less than two standard deviations below mean))). bo-controlled studies seems warranted. Future studies of tocolytic agents should measure all important short- and long-term outcomes for women and infants, and costs."
Flenady V, Wojcieszek AM, Papatsonis DNM, Stock OM, Murray L, Jardine LA, et al. Calcium channel blockers for inhibiting preterm labour and birth. Cochrane Database of Systematic Reviews 2014, Issue 6.

\section{Primary outcomes include:}

- Serious infant outcome (defined as death or chronic lung disease (need for supplemental oxygen at 28 days of life or later), grade three or four intraventricular haemorrhage (IVH) or periventricular leukomalacia (PVL), major neurosensory disability (defined as any of: legal blindness, sensorineural deafness requiring hearing aids, moderate or severe cerebral palsy, or developmental delay or intellectual impairment (defined as developmental quotient (DQ) or intelligence quotient (IQ) less than two standard deviations below mean))).

Secondary outcomes for the infant or child include:

- Blindness, deafness, cerebral palsy.
"Calcium channel blockers (CCB; mainly nifedipine) for women in preterm labour have benefits over placebo or no treatment in terms of postponement of birth, thus, theoretically allowing time for administration of antenatal corticosteroids and transfer to higher level care. Calcium channel blockers were shown to have benefits over betamimetics with respect to prolongation of pregnancy, serious neonatal morbidity, and maternal adverse effects. Calcium channel blockers may also have some benefits over ORAs and magnesium sulphate, although ORAs results in fewer maternal adverse effects. However, it must be noted that no difference was shown in perinatal mortality, and data on longer-term outcomes were limited. Further, the lack of blinding of the intervention diminishes the strength of this body of evidence. Further well-designed tocolytic trials are required to determine short- and longer-term infant benefit of CCBs over placebo or no treatment and other tocolytics, particularly ORAs. Another important focus for future trials is identifying optimal dosage regimens of different types of CCBs (high versus low, particularly addressing speed of onset of uterine quiescence), and formulation (capsules versus tablets). All future trials on tocolytics for women in preterm labour should employ blinding of the intervention and outcome assessment, include measurement of longer-term effects into early childhood, and also costs."
Grivell RM, Alfirevic Z, Gyte GML, Devane D. Antenatal cardiotocography for fetal assessment. Cochrane Database of Systematic Reviews 2015, Issue 9.

\section{Secondary outcomes include:}

- Cerebral palsy at 12 months.
"There is no clear evidence that antenatal CTG improves perinatal outcome, but further studies focusing on the use of computerised CTG in specific populations of women with increased risk of complications are warranted."
Grivell RM, Wong L, Bhatia V. Regimens of fetal surveillance for impaired fetal growth. Cochrane Database of Systematic Reviews 2012, Issue 6.
Secondary outcomes for the infant include:

- Cerebral palsy.
"There is limited evidence from randomised controlled trials to inform best practice for fetal surveillance regimens when caring for women with pregnancies affected by impaired fetal growth. More studies are needed to evaluate the effects of currently used fetal surveillance regimens in impaired fetal growth."
Haas DM, Morgan AM, Deans SJ, Schubert FP. Ethanol for preventing preterm birth in threatened preterm labor. Cochrane Database of
Secondary outcomes for the fetus, neonate, or infant include:

- Serious infant outcome (defined as death or chronic lung disease (need for supplemental oxygen at 28 days of life
"This review is based on evidence from twelve studies, which were mostly low quality. There is no evidence to suggest that ethanol is an effective tocolytic compared to placebo. There is some evidence that ethanol may be better tolerated than other tocolytics (in this case betamimetics), but this result is based on few studies and small sample sizes and therefore, should be interpreted with caution. Ethanol appears to be inferior to betamimetics for preventing preterm birth 
(Continued)

Systematic Reviews

2015, Issue 11. or later), grade three or four intraventricular hemorrhage or periventricular leukomalacia, major neurosensory disability (defined as any of: legal blindness, sensorineural deafness requiring hearing aids, moderate or severe cerebral palsy, or developmental delay or intellectual impairment (defined as developmental quotient (DQ) or intelligence quotient (IQ) less than two standard deviations below mean))).
Heazell AEP, Whitworth M, Duley L, Thornton JG. Use of biochemical tests of placental function for improving pregnancy outcome. Cochrane Database of Systematic Reviews 2015, Issue 11.
Secondary outcomes for the baby include:

- Neurodevelopment in childhood (cerebral palsy, neurodevelopmental delay). in threatened preterm labor. Ethanol is generally no longer used in current practice, due to safety concerns for the mother and her baby. There is no need for new studies to evaluate the use of ethanol for preventing preterm birth in threatened preterm labour. However, it would be useful for long-term follow-up studies on the babies born to mothers from the existing studies, in order to assess the risk of long-term neurodevelopmental status."
"There is insufficient evidence to support the use of biochemical tests of placental function to reduce perinatal mortality or increase identification of small-for-gestational-age infants. However, we were only able to include data from two studies that measured oestrogens and hPL. The quality of the evidence was low or very low. Two of the trials were performed in the 1970 s, on women with a variety of antenatal complications, and this evidence cannot be generalised to women at low-risk of complications or groups of women with specific pregnancy complications (e.g. fetal growth restriction). Furthermore, outcomes described in the 1970s may not reflect what would be expected at present. For example, neonatal mortality rates have fallen substantially, such that an infant delivered at 28 weeks would have a greater chance of survival were those studies repeated; this may affect the primary outcome of the meta-analysis. With data from just two studies (740 women), this review is underpowered to detect a difference in the incidence of death of a baby or the frequency of a small-for-gestational-age infant, as these have a background incidence of approximately $0.75 \%$ and $10 \%$ of pregnancies, respectively. Similarly, this review is underpowered to detect differences between serious or rare adverse events, such as severe neonatal morbidity. Two of the three included studies were quasi-randomised, with significant risk of bias from group allocation. Additionally, there may be performance bias, as in one of the two studies contributing data, participants receiving standard care did not have venipuncture, so clinicians treating participants could identify which arm of the study they were in. Future studies should consider more robust randomisation methods and concealment of group allocation, and should be adequately powered to detect differences in rare adverse events. The studies identified in this review examined two different analytes: oestrogens and hPL. There are many other placental products that could be employed as surrogates of placental function, including: placental growth factor (PIGF), human chorionic gonadotrophin (hCG), plasma protein A (PAPP-A), placental protein 13 (PP-13), pregnancy-specific glycoproteins, and progesterone metabolites, and further studies should be encouraged to investigate these other placental products. Future randomised controlled trials should test analytes identified as having the best predictive reliability for placental dysfunction leading to small-for-gestational-age infants and perinatal mortality."

\footnotetext{
Jahanfar S, Jaafar SH. Effects of restricted caffeine intake by mother on fetal, neonatal and
} pregnancy outcomes.
"There is insufficient evidence to confirm or refute the effectiveness of caffeine avoidance on birthweight or other pregnancy outcomes. There is a need to conduct high-quality, double-blinded RCTs to determine whether caffeine has any effect on pregnancy outcome." 
(Continued)

Cochrane Database of

Systematic Reviews

2015, Issue 6.

Khanprakob T, Laopai-

boon M, Lumbiganon

$\mathrm{P}$, Sangkomkamhang

US. Cyclo-oxygenase

(COX) inhibitors for pre-

venting preterm labour.

Cochrane Database of

Systematic Reviews

2012, Issue 10.
Secondary neonatal outcomes include:

- Long-term outcomes, for example developmental delay, cerebral palsy, educational attainment, etc.
"There was very little evidence about using COX-inhibitors for preventing preterm labour. There are inadequate data to make any recommendation about using COX-inhibitor in practice to prevent preterm labour. Future research should include follow-up of the babies to examine the short-term and long-term effects of COX inhibitors."
Lalor JG, Fawole B, Alfirevic Z, Devane D. Biophysical profile for fetal assessment in high risk pregnancies. Cochrane Database of Systematic Reviews 2008, Issue 1
Outcomes for the infant include:

- Disability to include non-ambulant cerebral palsy at or after 12 months of age, sensory impairment (visual, hearing), or both
"At present, there is insufficient evidence from randomised trials to support the use of biophysical profile (BPP) as a test of fetal well-being in high-risk pregnancies."

\section{Li W, Tang L, Wu T, Zhang J, Liu GJ, Zhou \\ Secondary outcomes for the neonate include:} L. Chinese herbal medicines for treating preeclampsia. Cochrane Database of Systematic Reviews 2006, Issue 2.
- Measures of long-term growth and development, such as important impairment and cerebral palsy.
No included trials.

"The efficacy and safety of Chinese herbal medicines for treating preeclampsia remains unclear. There are no randomised controlled trials in this field. High-quality randomised controlled trials are urgently required."

\section{Makrides M, Du- ley L, Olsen SF. Ma- rine oil, and other prostaglandin pre- cursor, supplementa- tion for pregnancy un- complicated by pre- eclampsia or intrauter- ine growth restriction. Cochrane Database of Systematic Reviews 2006, Issue 3.}

Outcomes for the baby include:

- Long-term follow-up included measures of neurological and developmental outcome (such as cerebral palsy).
"There is not enough evidence to support the routine use of marine oil, or other prostaglandin precursors, supplements during pregnancy to reduce the risk of pre-eclampsia, preterm birth, low birthweight, or small-for-gestational age."
McNamara $\mathrm{HC}$, Crowther CA, Brown J. Different treatment regimens of magnesium sulphate for tocolysis in women in preterm labour. Cochrane Database of Systematic Reviews 2015, Issue 12.
Primary outcomes for the infant or child include:

- Composite serious infant outcome (defined as death or chronic lung disease (oxygen requirement at 28 days of life or later); intraventricular haemorrhage (IVH; grade three or four), or periventricular leuco malacia (PVL); major neurosensory disability (defined as any of legal blindness, sensorineural deafness requiring hearing aids, moderate or severe cerebral palsy, or developmental delay or

\begin{abstract}
"There are limited data available (three studies, with data from only two studies) comparing different dosing regimens of magnesium sulphate given as single agent tocolytic therapy for the prevention of preterm birth. There is no evidence examining duration of therapy, timing of therapy, and the role for repeat dosing. Downgrading decisions for our primary outcome of fetal, neonatal, and infant death were based on wide confidence intervals (crossing the line of no effect), lack of blinding, and a limited number of studies. No data were available for any of our other important outcomes: birth less than 48 hours after trial entry; composite serious infant outcome; composite serious maternal outcome. The data are limited by volume and the outcomes reported. Only eight of our 45 pre-specified primary and secondary maternal and infant health outcomes were reported on in the included studies. No long-term outcomes were reported. Downgrading decisions for the evidence on the risk of respiratory distress were based on wide confidence intervals (crossing the line of no effect), and lack of blinding. There is some evidence from a single study,
\end{abstract}


(Continued)

intellectual impairment (defined as developmental quotient or intelligence quotient less than two standard deviations below the mean)).

Secondary outcomes for the child include:

- Cerebral palsy (mild, moderate, or severe, evaluated separately).
Outcomes for the child include:

Meher S, Duley L. Rest during pregnancy for preventing pre-eclampsia and its complications in women with normal blood pressure. Cochrane Database of Systematic Reviews 2006, Issue 2. suggesting a reduction in the length of stay in the neonatal intensive care unit and a reduced risk of respiratory distress syndrome, where a high-dose regimen of magnesium sulphate has been compared with a low-dose regimen. However, given that evidence has been drawn from a single study (with a small sample size), these data should be interpreted with caution. Magnesium sulphate has been shown to be of benefit in a wide range of obstetric settings, although it has not been recommended for tocolysis. In clinical settings where health benefits are established, further trials are needed to address the lack of evidence regarding the optimal dose (loading dose and maintenance dose), duration of therapy, timing of therapy, and role for repeat dosing, in terms of efficacy and safety for mothers and their children. Ongoing examination of different regimens with respect to important health outcomes is required."

"Daily rest, with or without nutrient supplementation, may reduce the risk of pre-eclampsia for women with normal blood pressure, although the reported effect may reflect bias, random error, or both, rather than a true effect. There is no information about outcomes such as perinatal mortality and morbidity, maternal morbidity, women's views, adverse effects, and costs. Current evidence is insufficient to support recommending rest or reduced activity to women for preventing pre-eclampsia and its complications. Whether women rest during pregnancy should therefore be a matter of personal choice."

"There is insufficient evidence for reliable conclusions about the effects of progesterone for preventing pre-eclampsia and its complications. Therefore, progesterone should not be used for this purpose in clinical practice at present." opment: blindness, deafness, seizures, poor growth, neurodevelopmental delay, and
- Long-term growth and develcerebral palsy.
Meher S, Duley L. Progesterone for preventand its complications. Cochrane Database of Systematic Reviews 2006, Issue 4
Secondary outcomes for the child include:

Outcomes for the child include:

Meher S, Duley L. Nitric oxide for preventing pre-eclampsia and its complications. Cochrane Database of Systematic Reviews 2007, Issue 2 .
- Long-term growth and development: blindness, deafness, seizures, poor growth, neurodevelopmental delay, and cerebral palsy.
"There is insufficient evidence to draw reliable conclusions about whether nitric oxide donors and precursors prevent pre-eclampsia or its complications."
Meher S, Duley L. Garlic for preventing preeclampsia and its complications. Cochrane Database of Systematic Reviews 2006, Issue 3.

\section{Outcomes for the child include:}

- Long-term growth and development: blindness, deafness, seizures, poor growth, neurodevelopmental delay, and cerebral palsy.
"There is insufficient evidence to recommend increased garlic intake for preventing pre-eclampsia and its complications. Although garlic is associated with odour, other more serious side-effects have not been reported. Further large randomised trials evaluating the effects of garlic are needed before any recommendations can be made to guide clinical practice."

\footnotetext{
Meher S, Duley L. Exercise or other physical activity for preventing pre-eclampsia and its complications. Cochrane Database of Systematic Reviews 2006, Issue 2.
}

Outcomes for the child include:

- Long-term growth and development: blindness, deafness, seizures, poor growth, neurodevelopmental delay, and cerebral palsy.
"There is insufficient evidence for reliable conclusions about the effects of exercise on prevention of pre-eclampsia and its complications." 
(Continued)

Naik Gaunekar N, Raman P, Bain E, Crowther

CA. Maintenance therapy with calcium channel blockers for preventing preterm birth after threatened preterm labour. Cochrane Database of Systematic Reviews 2013, Issue 10.
Primary outcomes include:

- Any neurological disability at paediatric follow-up (impairment of vision, hearing, intelligence, or cerebral palsy).
"Based on the current available evidence, maintenance treatment with a calcium channel blocker after threatened preterm labour does not prevent preterm birth or improve maternal or infant outcomes."
Nanda K, Cook LA, Gallo MF, Grimes DA. Terbutaline pump maintenance therapy after threatened preterm labor for preventing preterm birth. Cochrane Database of Systematic Reviews 2002, Issue 4.
Outcomes for the infant include:

- Neurological sequelae (general intelligence, hearing, vision, cerebral palsy, and disability).
"Terbutaline pump maintenance therapy has not been shown to decrease the risk of preterm birth by prolonging pregnancy. Furthermore, the lack of information on the safety of the therapy, as well as its substantial expense, argues against its role in the management of arrested preterm labor. Future use should only be in the context of well-conducted, adequately powered randomized controlled trials."
Neilson JP. Fetal electrocardiogram (ECG) for fetal monitoring during labour. Cochrane Database of Systematic Reviews 2015, Issue 12.
Secondary outcomes for the fetus include:

- Cerebral palsy.
"The modest benefits of fewer fetal scalp samplings during labour (in settings in which this procedure is performed) and fewer instrumental vaginal births have to be considered against the disadvantages of needing to use an internal scalp electrode, after membrane rupture, for ECG waveform recordings. We found little strong evidence that STwaveform analysis had an effect on the primary outcome measures in this systematic review. There was a lack of evidence showing that PR-interval analysis improved any outcomes; and a larger future trial may possibly demonstrate beneficial effects. There is little information about the value of fetal ECG waveform monitoring in preterm fetuses in labour. Information about long-term development of the babies included in the trials would be valuable."
Nguyen TMN, Crowther CA, Wilkinson D, Bain E. Magnesium sulphate for women at term for neuroprotection of the fetus. Cochrane Database of Systematic Reviews 2013, Issue 2.
Primary outcomes for the infant or child include:

- Death or cerebral palsy.

- Cerebral palsy (abnormality of tone with motor dysfunction (as diagnosed at 18 months of age or (ater)).

Secondary outcomes for the child include:

- Any neurological disabilities (defined as developmental delay or intellectual impairment, blindness (corrected visual acuity worse than $6 / 60$ in the better eye), deafness (hearing loss requiring amplification or worse), cerebral palsy, motor dysfunction). The severity of the disability due to cerebral palsy will be graded into severe, moderate, and mild. Se-
"There is currently insufficient evidence to assess the efficacy and safety of magnesium sulphate when administered to women for neuroprotection of the term fetus. As there has been recent evidence for the use of magnesium sulphate for neuroprotection of the preterm fetus, high-quality randomised controlled trials are needed to determine the safety profile and neurological outcomes for the term fetus. Strategies to reduce maternal side effects during treatment also require evaluation." 
(Continued)

vere disability will include children who are non-ambulant and are likely to remain so, moderate disability will comprise those children who have substantial limitation of movement, and mild disability will comprise those children walking with little limitation of movement. The neurosensory disabilities imposed by the various sensorineural impairments will be classified as severe, moderate, and mild, as follows: Severe disability will comprise any of severe cerebral palsy, an intelligence quotient (IQ) less than three standard deviations (SD) below the mean, or blindness. Moderate disability will comprise moderate cerebral palsy, deafness, or an IQ from minus three SD to less than two SD below the mean. Mild disability will comprise mild cerebral palsy or an IQ from minus two SD to less than one SD below the mean.

- Major neurological disability (defined as any of: legal blindness, neurosensory deafness requiring hearing aids, moderate or severe cerebral palsy, or moderate or severe developmental delay or intellectual impairment (defined as developmental quotient or IQ less than two SD below the mean)).

Ohlsson A, Shah VS, Stade BC. Vaginal chlorhexidine during labour to prevent early-onset neonatal group B streptococcal infection. Cochrane Database of Systematic Reviews 2014, Issue 12.
Secondary intellectual impairment outcomes include:

- Long-term neurological sequelae, which may include cognitive delay, cerebral palsy, cortical blindness, deafness, hydrocephalus, or a combination.
"The quality of the four included trials varied, as did the risk of bias, and the quality of the evidence using GRADE, was very low. Vaginal chlorhexidine was not associated with reductions in any of the primary outcomes of early-onset GBS disease (sepsis, meningitis, or both), or GBS pneumonia. Vaginal chlorhexidine may reduce GBS colonization of neonates. The intervention was associated with an increased risk of maternal mild adverse effects. The review currently does not support the use of vaginal disinfection with chlorhexidine in labour for preventing early-onset disease. Results should be interpreted with caution as the methodological quality of the studies was poor. As early-onset GBS disease is a rare condition, trials with very large sample sizes are needed to assess the effectiveness of vaginal chlorhexidine, to reduce its occurrence. In the era of intrapartum antibiotic prophylaxis, such trials may be difficult to justify, especially in developed countries."
Papatsonis DNM, Flenady V, Liley HG. Main-
Primary outcomes include:

"There is insufficient evidence to support the use of oxytocin receptor antagonists to inhibit preterm birth after a period of threatened 
(Continued) tenance therapy with oxytocin antagonists for inhibiting preterm birth after threatened preterm labour. Cochrane Database of Systematic Reviews 2013, Issue 10.
- Perinatal or infant mortality, or any neurological disability at long-term paediatric follow-up at two years of age (vision impairment, sensorineural deafness requiring hearing aids, cerebral palsy, or developmental delay or intellectual impairment). or actual preterm labour. Any future trials using oxytocin antagonists or other drugs as maintenance therapy for preventing preterm birth should examine a variety of important infant outcome measures, including reduction of neonatal morbidity and mortality, and long-term infant follow-up. Future research should also focus on the pathophysiological pathways that precede preterm labour."
Phipps $\mathrm{H}$, de Vries B, Hyett J, Osborn DA. Prophylactic manual rotation for fetal malposition to reduce operative delivery. Cochrane Database of Systematic Reviews 2014, Issue 12.
Secondary outcomes for the neonate and infant include:

- Severe neurodevelopmental disability in infants (assessed at 12 months of age or older), defined as any one or combination of the following: nonambulant cerebral palsy, severe developmental delay assessed using validated tools, auditory and visual impairment.
"Currently, there is insufficient evidence to determine the efficacy of prophylactic manual rotation early in the second stage of labour for prevention of operative delivery. One additional study is ongoing. Further appropriately designed trials are required to determine the efficacy of manual rotation."

Reinebrant HE, Pileg-
gi-Castro C, Romero
CLT, dos Santos RAN,
Kumar S, Souza JP, et
al. Cyclo-oxygenase
(COX) inhibitors for
treating preterm labour.
Cochrane Database of
Systematic Reviews
2015, Issue 6.

Primary outcomes include:

- Serious infant outcome death or major sensorineural disability at two years of age (defined as any one or more of the following: legal blindness, sensorineural deafness requiring hearing aids, moderate or severe cerebral palsy, or developmental delay or intellectual impairment (defined as developmental quotient or intelligence quotient less than two standard deviations below the mean)).
"In this review, no clear benefit for COX inhibitors was shown over placebo or any other tocolytic agents. While some benefit was demonstrated in terms of postponement of birth for COX inhibitors over placebo and betamimetics, and also maternal adverse effects over betamimetics and $\mathrm{MgSO} 4$, due to the limitations of small numbers, minimal data on safety, lack of longer-term outcomes, and generally low quality of the studies included in this review, we conclude that there is insufficient evidence on which to base decisions about the role of COX inhibition for women in preterm labour. Further well-designed tocolytic studies are required to determine short- and longer-term infant benefit of COX inhibitors over placebo and other tocolytics, particularly CCBs and ORAs. Another important focus for future studies is identifying whether COX-2 inhibitors are superior to non-selective COX inhibitors. All future studies on tocolytics for women in preterm labour should assess longer-term effects into early childhood and also costs."
Secondary outcomes for the child include:

Rumbold A, Duley Crowther CA, Haslam RR. Antioxidants for preventing pre-eclampsia. Cochrane Database of Systematic Reviews 2008, Issue 1.
- Disability during childhood (such as cerebral palsy, intellectual disability, hearing disability, and visual impairment).

\begin{abstract}
"Evidence from this review does not support routine antioxidant supplementation during pregnancy to reduce the risk of pre-eclampsia and other serious complications in pregnancy."
\end{abstract}

Secondary outcomes for the neonate include:

Rumbold A, Ota E, Ho $\mathrm{H}$, Miyazaki C, Crowther CA. Vitamin E supplementation in pregnancy. Cochrane Database of Systematic Reviews 2015, Issue 9.
- Disability at childhood follow-up (such as cerebral palsy, intellectual disability, hearing disability, and visual impairment).
"The data do not support routine vitamin E supplementation in combination with other supplements for the prevention of stillbirth, neonatal death, preterm birth, pre-eclampsia, preterm or term PROM, or poor fetal growth. Further research is required to elucidate the possible role of vitamin $E$ in the prevention of placental abruption. There was no convincing evidence that vitamin E supplementation in combination with other supplements results in other important benefits or harms."

\footnotetext{
Rumbold A, Ota E, Na- Secondary outcomes for the $\quad$ "The data do not support routine vitamin C supplementation alone Antenatal and intrapartum interventions for preventing cerebral palsy: an overview of Cochrane systematic reviews (Review) 
(Continued)

Crowther CA. Vitamin C supplementation in pregnancy. Cochrane Database of Systematic Reviews 2015, Issue 9.
- Disability at childhood follow-up (such as cerebral palsy, intellectual disability, hearing disability, and visual impairment). or neonatal death, poor fetal growth, preterm birth, or pre-eclampsia. Further research is required to elucidate the possible role of vitamin $\mathrm{C}$ in the prevention of placental abruption and pre-labour rupture of membranes. There was no convincing evidence that vitamin $C$ supplementation alone or in combination with other supplements results in other important benefits or harms."
Shub A, Walker SP. Planned early delivery versus expectant management for monoamniotic twins. Cochrane Database of Systematic Reviews 2015, Issue 4.
Secondary outcomes for the infant include:

- Cerebral palsy.
No included trials.

"Monoamniotic twins are rare, and there is insufficient randomised controlled evidence on which to draw strong conclusions about the best management. In their absence, we can refer to historical case series and expert consensus. Management plans should take into consideration the availability of high-quality neonatal care if early delivery is chosen. Women and their families should be involved in the decision-making about these high-risk pregnancies. Ongoing, multicentre audits of maternal and perinatal outcomes for monoamniotic twins are needed in order to inform families and clinicians about up-to-date perinatal outcomes with contemporary obstetric practice. Research should consider the social and economic implications of planned interventions, as well as the perinatal outcomes."
Spencer L, Bubner T, Bain E, Middleton P. Screening and subsequent management for thyroid dysfunction pre-pregnancy and during pregnancy for improving maternal and infant health. Cochrane Database of Systematic Reviews 2015, Issue 9.
Primary outcomes for the infant as a child include:

- Neurosensory disability (any of: cerebral palsy, blindness, deafness, developmental delay, intellectual impairment, at latest time reported).

Secondary outcomes for the infant as a child include:

- Cerebral palsy.
"Though universal screening versus no screening for hypothyroidism similarly increased diagnosis and subsequent treatment, no clear difference was seen for the primary outcome: neurosensory disability for the infant as a child (IQ less than 85 at three years); data were lacking for the other primary outcomes: pre-eclampsia and preterm birth, and for the majority of secondary outcomes, including miscarriage and fetal or neonatal death. For outcomes assessed using the GRADE approach, the evidence was considered to be moderate or high quality, with any downgrading of the evidence based on the presence of wide confidence intervals crossing the line of no effect.

More evidence is needed to assess the benefits or harms of different screening methods for thyroid dysfunction in pregnancy, on maternal, infant and child health outcomes. Future trials should assess impacts on use of health services and costs, and be adequately powered to evaluate the effects on short- and long-term outcomes."
Thinkhamrop J, Hofmeyr GJ, Adetoro O, Lumbiganon P, Ota E. Antibiotic prophylaxis during the second and third trimester to reduce adverse pregnancy outcomes and morbidity. Cochrane Database of Systematic Reviews 2015, Issue 6 .

\section{Secondary outcomes for the} neonate pre-specified include:

- Childhood cerebral palsy.
"Antibiotic prophylaxis did not reduce the risk of preterm pre-labour rupture of membranes or preterm delivery (apart from in the subgroup of women with a previous preterm birth who had bacterial vaginosis). Antibiotic prophylaxis given during the second or third trimester of pregnancy reduced the risk of postpartum endometritis, term pregnancy with pre-labour rupture of membranes and gonococcal infection when given routinely to all pregnant women. Substantial bias possibly exists in the review's results because of a high rate of loss to follow-up, and the small numbers of studies included in each of our analyses. There is also insufficient evidence on possible harmful effects on the baby. Therefore, we conclude that there is not enough evidence to support the use of routine antibiotics during pregnancy to prevent infectious adverse effects on pregnancy outcomes."

"There is insufficient evidence to recommend the routine use of home visits for pregnant or postpartum women with a drug or alcohol problem. Further large, high-quality trials are needed."
Turnbull C, Osborn DA. Home visits during pregnancy and after birth for women with an alcohol or drug problem. Cochrane Data-
Outcomes for the infant or child include:

- Disability (cerebral palsy, sensorineural impairment, or significant developmental delay). 
(Continued)

base of Systematic Re-

views 2012, Issue 1.

\section{Utama DP, Crowther}

CA. Transplacental versus direct fetal corticosteroid treatment for accelerating fetal lung maturation where there is a risk of preterm birth. Cochrane Database of Systematic Reviews 2011, Issue 9.
Secondary outcomes for the infant or child include:

- Cerebral palsy (however defined by authors).
Vogel JP, Nardin JM, Dowswell T, West HM, Oladapo OT. Combination of tocolytic agents for inhibiting preterm labour. Cochrane Database of Systematic Reviews 2014, Issue 7.

\section{Primary outcomes include:}

- Short-term and long-term serious infant outcome (see definition below), determined by the presence of any of the following: death; chronic lung disease (use of supplemental oxygen therapy at 36 weeks' postmenstrual age, or at 28 days of life, or later); grade three or four intraventricular haemorrhage or periventricular leukomalacia; major sensorineural disability at two years of age, defined as any one or more of the following: severe or profound vision impairment, sensorineural deafness requiring hearing aids, moderate or severe cerebral palsy or developmental delay or intellectual impairment (defined as developmental quotient or intelligence quotient less than two standard deviations below the mean).

\section{No included trials.}

"The available clinical studies carried out so far on animals and humans have shown that direct intramuscular injection of corticosteroid into the fetus under ultrasound guidance is feasible, but data on health outcomes are lacking. Therefore, uncertainty persists as to which method could provide better efficacy and safety profile. Randomised controlled trials are required, focusing on the benefits and harms of transplacental versus direct fetal corticosteroid treatment. Until the uncertainties have been answered, it is advisable to stay with the current standard of antenatal transplacental maternally administered corticosteroid treatment."
"It is unclear whether a combination of tocolytic drugs for preterm labour is more advantageous for women, newborns, or both, due to a lack of large, well-designed trials including the outcomes of interest. There are no trials of combination regimens using widely used tocolytic agents, such as calcium channel blockers (nifedipine), oxytocin receptor antagonists (atosiban), or both. Further trials are needed before specific conclusions on use of combination tocolytic therapy for preterm labour can be made."

\footnotetext{
Waterfall H, Grivell RM, Dodd JM. Techniques for assisting difficult delivery at caesarean section. Cochrane Database of Systematic Reviews 2016, Issue 1.
}

\begin{abstract}
Secondary outcomes for the infant include:

- Cerebral palsy.

"There is currently insufficient information available from randomised trials to support or refute the routine or selective use of tocolytic agents or instrument to facilitate infant birth at the time of difficult caesarean section. There is limited evidence that reverse breech extraction may improve maternal and fetal outcomes, though there was no difference in primary outcome of infant birth trauma. Further randomised controlled trials are needed to answer these questions."
\end{abstract}

"There is insufficient evidence to support or refute the use of prophylactic oral betamimetics for preventing preterm birth in women at high risk of preterm labour with a singleton pregnancy."

\footnotetext{
Whitworth M, Quenby S. Prophylactic oral betamimetics for preventing preterm labour in singleton pregnancies. Cochrane Database of Systematic Reviews 2008, Issue 1.
}

\section{Primary outcomes include:}

- Death at childhood follow-up at greater than, or equal to, 12 months of age (corrected for preterm birth), or severe neurodevelopmental disability defined as any one 
or combination of the following: non-ambulant cerebral palsy, developmental delay (developmental quotient less than 70 , or more than two standard deviations below the mean), severe auditory impairment (sensorineural deafness requiring hearing aids), or visual impairment (legal blindness).
Whitworth M, Quenby S, Secondary outcomes for the inCockerill RO, Dowswell fant include:

T. Specialised antenatal clinics for women with a pregnancy at high risk of preterm birth (excluding multiple pregnancy) to improve maternal and infant outcomes. Cochrane Database of Systematic Reviews 2011, Issue 9.
- Disability at childhood follow-up (including deafness, blindness, neurodisability, or cerebral palsy).
"Specialised antenatal clinics are now an accepted part of care in many settings, and carrying out further randomised trials may not be possible. Any future research in this area should include psychological outcomes, and should focus on which aspects of service provision are preferred by women. Such research could underpin further service development in this area."
Wilkinson D, Shepherd E, Wallace EM. Melatonin for women in pregnancy for neuroprotection of the fetus. Cochrane Database of Systematic Reviews 2016, Issue 3.
Primary outcomes for the infant or child include:

- Death or any neurosensory disability (at latest time reported); this combined outcome recognises the potential for competing risks of death or survival with neurological problems.

- Neurosensory disability (any of: cerebral palsy, blindness, deafness, developmental delay or intellectual impairment), at latest time reported.

Secondary outcomes for the infant or child include:

- Cerebral palsy (any, and graded as: severe: including children who are non-ambulant and are likely to remain so; moderate: including those children who have substantial limitation of movement; mild: including those children walking with little limitation of movement).

- Death or cerebral palsy.

- Major neurosensory disability (defined as any of: moderate or severe cerebral palsy, legal blindness, neurosensory deafness requiring hearing

\section{No included trials.}

"As we did not identify any randomised trials for inclusion in this review, we are unable to comment on implications for practice at this stage. Although evidence from animals studies has supported a fetal neuroprotective role for melatonin when administered to the mother during pregnancy, no trials assessing melatonin for fetal neuroprotection in pregnant women have been completed to date. However, there is currently one ongoing randomised controlled trial (with an estimated enrolment target of 60 pregnant women), which examines the dose of melatonin, administered to women at risk of imminent, very preterm birth (less than 28 weeks' gestation), required to reduce brain damage in the white matter of the babies that were born very preterm. Further high-quality research is needed, and research efforts should be directed towards trials comparing melatonin with either no intervention (no treatment or placebo), or with alternative agents aimed at providing fetal neuroprotection (such as magnesium sulphate for the very preterm infant). Such trials should evaluate maternal and infant short- and longer-term outcomes (including neurosensory disabilities such as cerebral palsy), and consider the costs of care." 
(Continued)

aids, or moderate or severe developmental delay or intellectual impairment).

Woudstra DM, Chan-
dra S, Hofmeyr GJ,
Dowswell T. Corticos-
teroids for HELLP (he-
molysis, elevated liver
enzymes, low platelets)
syndrome in pregnan-
cy. Cochrane Database
of Systematic Reviews
2010, Issue 9.

Yamasmit W, Chaithongwongwatthana S, Tolosa JE, Limpongsanurak S, Pereira L, Lumbiganon P. Prophylactic oral betamimetics for reducing preterm birth in women with a twin pregnancy. Cochrane Database of Systematic Reviews 2015, Issue 12.

\section{Secondary outcomes for the} child include:

- Long-term growth and development: blindness, deafness, seizures, poor growth, neurodevelopmental delay, and cerebral palsy.
"There was no clear evidence of any effect of corticosteroids on substantive clinical outcomes. Those receiving steroids showed significantly greater improvement in platelet counts, which was greater for those receiving dexamethasone than those receiving betamethasone. There is to date, insufficient evidence of benefits in terms of substantive clinical outcomes to support the routine use of steroids for the management of HELLP. The use of corticosteroids may be justified in clinical situations in which increased rate of recovery in platelet count is considered clinically worthwhile."

\section{Secondary outcomes for the neonate or infant include:}

- Abnormal neurodevelopmental status at more than 12 months corrected age (developmental delay, cerebral palsy, or both).
"There is insufficient evidence to support or refute the use of prophylactic oral betamimetics for preventing preterm birth in women with a twin pregnancy."

\section{Key (in order of appearance)}

FENO-based - Fractional exhaled nitric oxide-based algorithm

PMR - progressive muscle relaxation

PTB - preterm birth

IVH - intraventricular haemorrhage

NICU - neonatal intensive care unit

CCB - calcium channel blockers

hPL - human placental lactogen

GBS - Group B Streptococcus

MgSO4 - magnesium sulphate

PROM - preterm rupture of membranes

\section{CONTRIBUTIONS OFAUTHORS}

Emily Shepherd drafted the first version of the protocol for this review, with Sarah Mclntyre, Maria Makrides, Philippa Middleton, and Caroline Crowther making comments and contributing to the final protocol.

Emily Shepherd and Rehana Salam assessed review eligibility and carried out all data extraction, quality assessment and data entry. Emily Shepherd authored initial drafts. Rehana Salam, Philippa Middleton, Maria Makrides, Sarah McIntyre, Nadia Badawi, and Caroline Crowther made comments and contributed to the final overview. 


\section{DECLARATIONS OF INTEREST}

The overview authors were authors of some of the Cochrane systematic reviews that were considered for inclusion in this review. Assessment of eligibility of any and all of these reviews, and where included, data collection and analysis (including quality assessment) for these reviews, was carried out by two overview authors not involved in the individual Cochrane reviews.

Emily Shepherd, Philippa Middleton, and Caroline Crowther are investigators on a Project Grant from the Cerebral Palsy Alliance Research Foundation, Australia, which supported the conduct of this overview.

Maria Makrides has served on scientific advisory boards for Nestle and Fonterra. Associated honoraria were paid to the Women's and Children's Health Research Institute to support conference travel and continuing education for postgraduate students and early career researchers.

Sarah McIntyre is employed by Cerebral Palsy Alliance and the University of Sydney. She has also been invited to a number of international meetings where travel costs have been paid by the organisers of the meeting, e.g. Surveillance of Cerebral Palsy Europe.

Rehana Salam: none know.

Nadia Badawi: none known.

\section{SOURCES OF SUPPORT}

\section{Internal sources}

- ARCH: Australian Research Centre for Health of Women and Babies, Robinson Research Institute, Discipline of Obstetrics and Gynaecology, The University of Adelaide, Australia.

\section{External sources}

- National Health and Medical Research Council, Australia Funding for the Australian and New Zealand Pregnancy and Childbirth Satellite, Australia.

- Cerebral Palsy Alliance Research Foundation, Australia.

Project Grant: PG0914 - Interventions during the antenatal and neonatal period to prevent cerebral palsy: an overview of Cochrane systematic reviews (Bain E, Middleton P, Crowther CA)

\section{INDEX TERMS}

\section{Medical Subject Headings (MeSH)}

*Parturition; Antibiotic Prophylaxis; Cerebral Palsy [epidemiology] [prevention \& control]; Fetal Distress [therapy]; Hypertension [therapy]; Infant, Premature; Magnesium Sulfate [therapeutic use]; Neuroprotective Agents [therapeutic use]; Pre-Eclampsia [therapy]; Pregnancy Complications, Cardiovascular [therapy]; Premature Birth [prevention \& control]; Prenatal Care [ ${ }^{\star}$ methods]; Randomized Controlled Trials as Topic; Review Literature as Topic

\section{MeSH check words}

Female; Humans; Pregnancy 